WRI INDONESIA
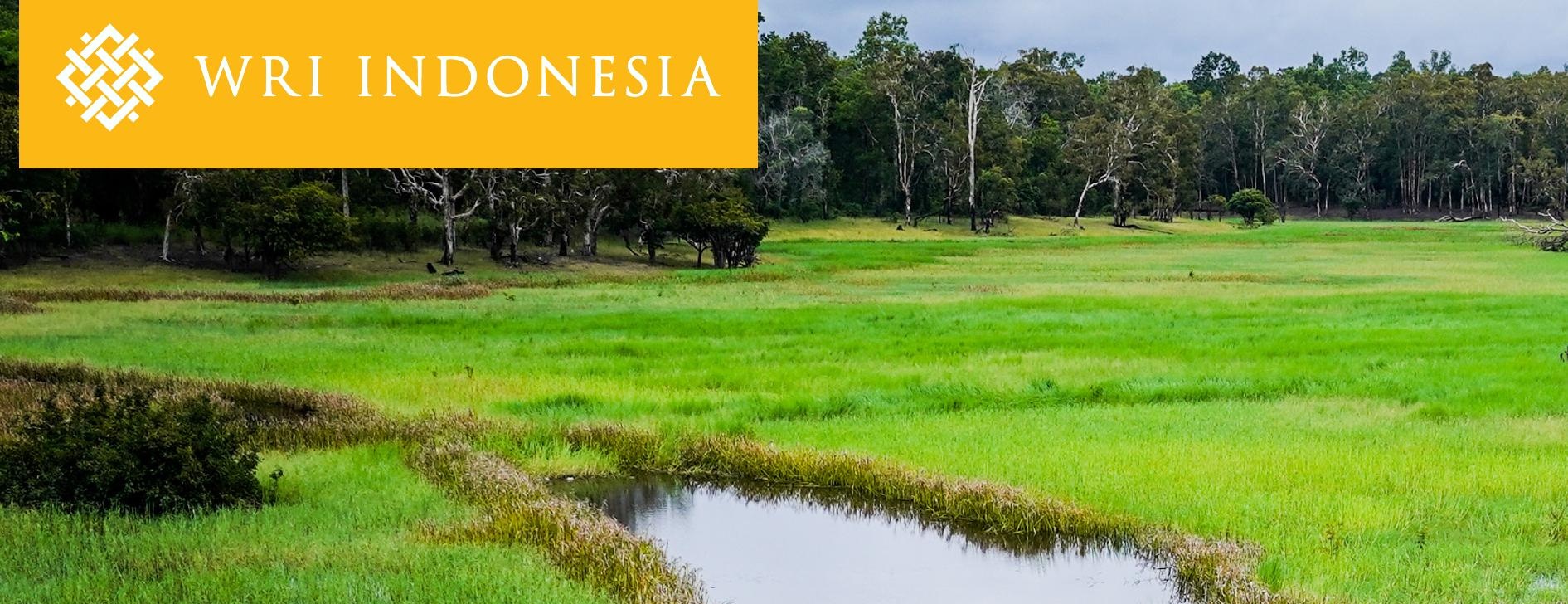

\title{
GAINING GROUND
}

\section{Institutional Barriers Hampering}

\section{Land Conflict Resolution in Indonesia}

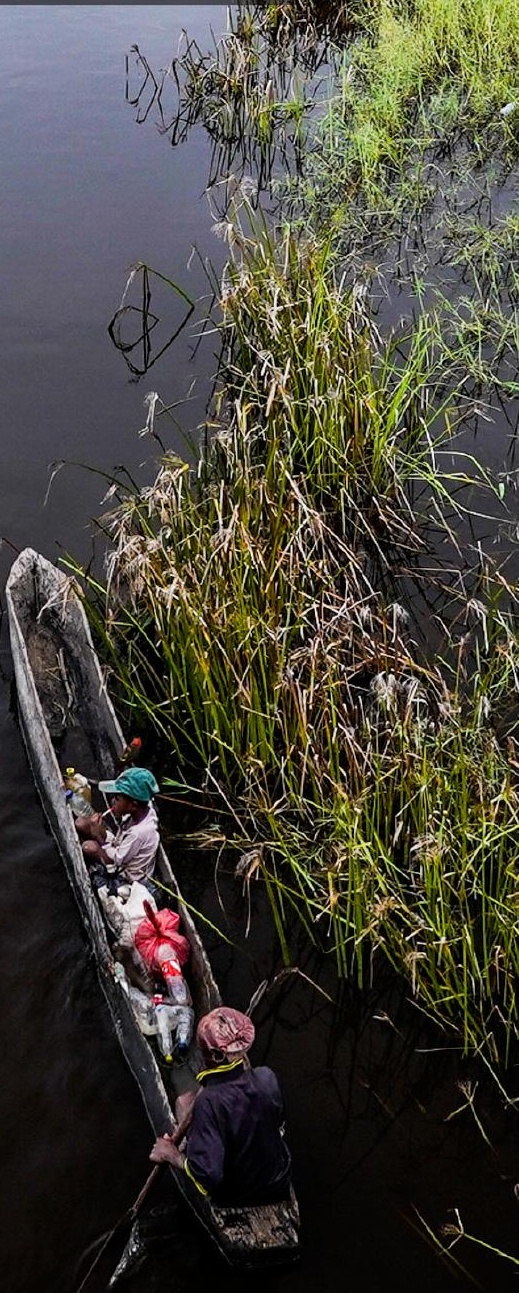




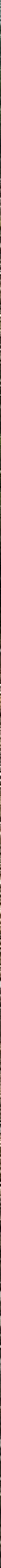




\section{TABLE OF CONTENTS}

v Foreword

1 Executive Summary

11 Introduction

13 Research Objectives

14 Data and Methodology

17 Understanding Land Conflicts in Indonesia

18 Land Governance and Institutions in Indonesia

23 The State of Land Conflict in Indonesia

29 Institutional Barriers Hampering Land Conflict Resolution

30 Strategies and Institutional Framework

36 Operational Framework

39 Land Governance and Political Will

43 CONCLUSION

46 Appendix A. Distribution Mapping of Land-Related Resolution Authorities

51 Appendix B. List of Laws and Regulations

52 Abbreviations

52 Endnotes

53 References 


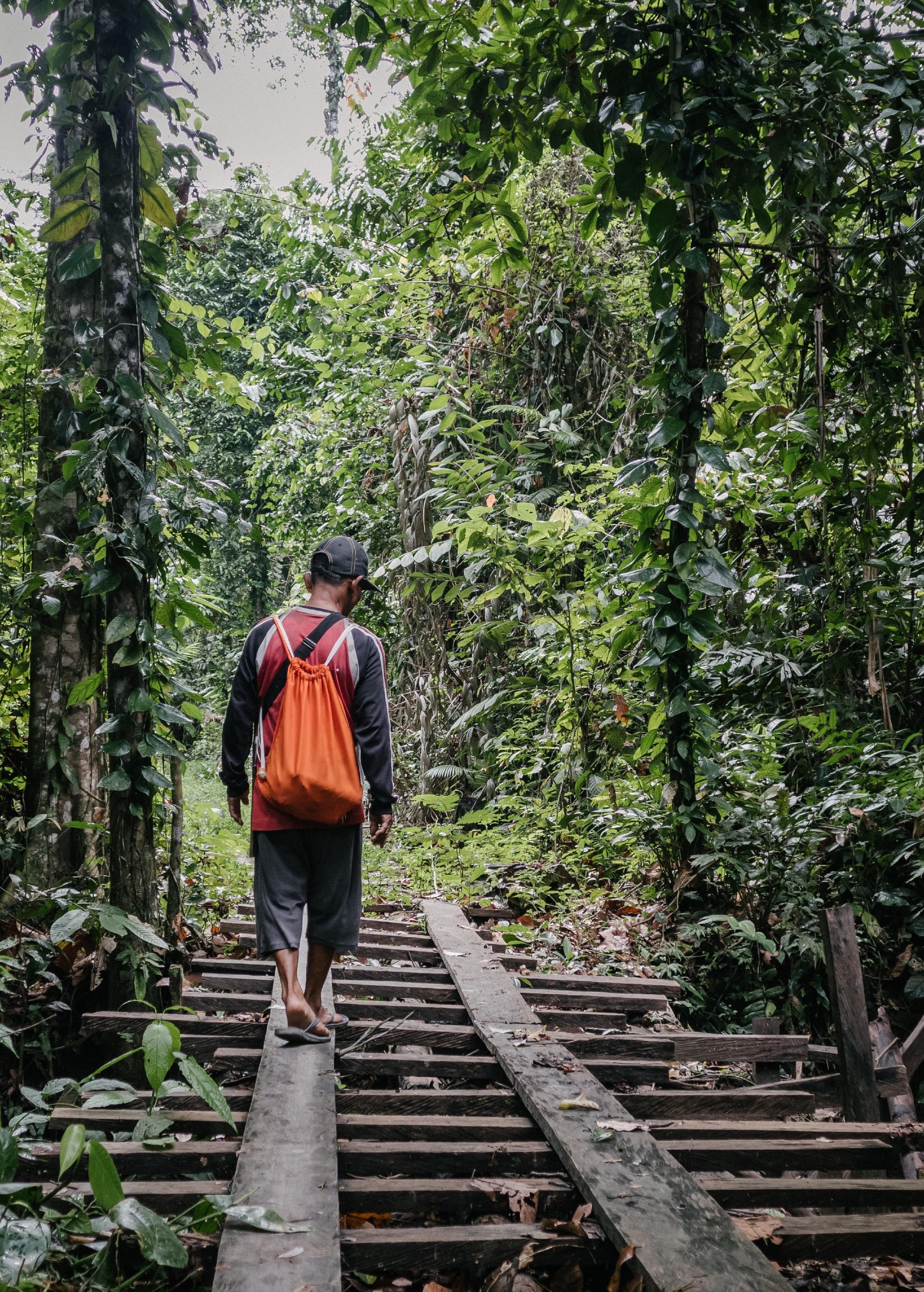




\section{FOREWORD}

Land conflicts are persistent obstacles in Indonesia's quest for sustainable development and are unescapable risks for many Indonesians. The twin health and economic crises triggered by COVID-19, and the ongoing climate crisis, have only added to their worries. In 2020, more than 130,000 families were ensnared by land conflicts, an increase of almost 25 percent from 2019. In Indonesia, land conflicts are closely related to poverty and inequality. Improving the lives and welfare of the Indonesian people without a coherent strategy to resolving land conflicts is a herculean challenge.

Land conflicts have remained a daunting obstacle to overcome because ownership, access, and control over land are deeply intertwined with many competing interests. Land remains vital for economic growth where agriculture and land-based sectors account for 17 percent of Indonesia's economy. Exports are geared towards land-based industries. The oil palm industry, for example, generates 20 percent of national export earnings. On a microscale, land is crucial for individual livelihoods. Approximately 30 percent of adults in Indonesia work in the agriculture, forestry, and fisheries industry. For others, including the many indigenous nations who continue to struggle for territory, land is an inseparable part of their cultural identity. With the demand for land increasing in Indonesia, the tensions between different groups in society will continue to heighten.

Land conflicts create significant uncertainties in Indonesia's land-use management, which also hamper the country's ability to accelerate economic growth and social development. They interfere with effective land-use and spatial planning as well as more sustainable forest management, which are crucial for Indonesia's strategy to reduce emissions and meet its nationally determined contribution.

The majority of existing research on land conflict resolution in Indonesia focuses on either the large-scale issues of land governance and policies or the mechanisms to resolve land conflicts at a case-by-case level. However, a critical research gap is on the institutions that carry out those policies and implement those mechanisms. Understanding how those institutions work is essential for delivering effective resolution of land conflicts.

This report is the first product in a series of research seeking the best design and arrangement of government and civil institutions to support effective and sustainable land conflict resolution in Indonesia. The study supports WRI Indonesia's work to develop programs and proposals to improve how tenurial conflicts are resolved. It also aims to inform stakeholders about critical areas to develop institutions that can more effectively resolve land conflicts nationwide.

This study presents an extensive dive into the national institutional barriers that currently hamper Indonesia's ability to efficiently resolve land conflicts. It explains how the land conflict resolution approach taken by authorities at the national level is often convoluted, having a long history of injustices and inequity. This report pieces together the various interconnected problems that institutions in Indonesia face through conversations with many stakeholders.

This report finds that a more comprehensive and coherent approach, with stronger coordination, accountability, and operational capacities, needs to be developed to address the lingering institutional obstacles that hamper land conflict resolution. To fulfill the 2030 Sustainable Development Goals and the 2024 Low Carbon Development Initiative's promise of a sustainable future and welfare for all, Indonesia should act swiftly and boldly on land conflicts.

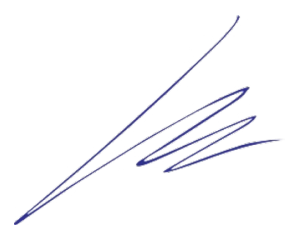

Dr. Nirarta Samadhi

Director

World Resources Institute Indonesia 


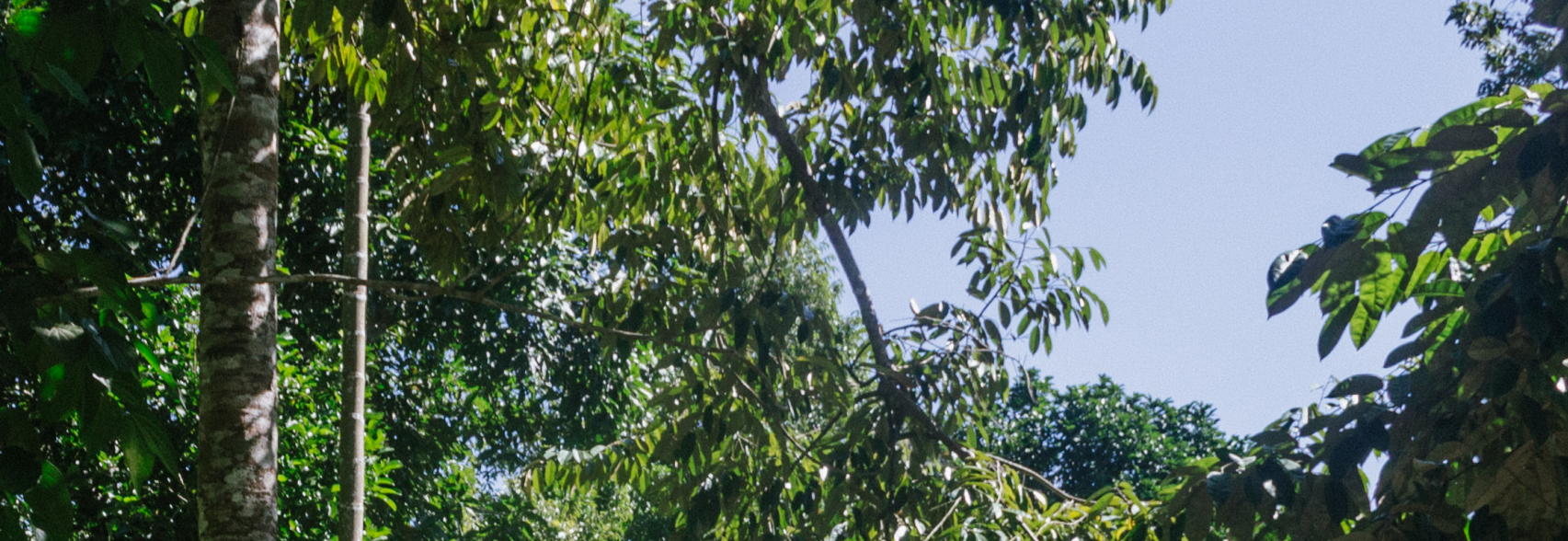

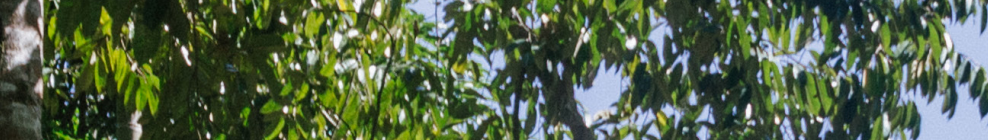




\section{EXECUTIVE SUMMARY}

Land conflicts continue to hamper Indonesia's ability to manage natural resources sustainably and equitably. The country must strengthen current institutions to resolve and prevent land conflicts from spiraling out of control. This report identifies the institutional barriers the government must overcome to tackle the country's persistent land conflicts. 


\section{Highlights}

- Based on an extensive investigation this report applauds the Indonesian government's current programs and initiatives to resolve land conflicts. Land conflicts threaten to slow down the country's economic development and equitable management of natural resources.

- However, more progress can be made, especially in overcoming institutional obstacles. This report identifies the institutional barriers the government will need to overcome to further address the country's persistent land conflicts.

- Among them, overly administrative, ad hoc, and reactive approaches have left the nation without a coherent strategy to address the underlying structural problems that continue to trap communities, corporations, and governments in land conflicts.

- This is compounded by a complex and scattered set of uncoordinated institutions and further weakened by a lack of skilled workers, clear operational mechanisms, accurate data information systems, and funding

- Corruption and conflicts of interest are rampant throughout Indonesia's land administration, which further intensifies the conflict between the powerful and the weak. The nation's top leaders will need to show leadership and strong political will to break the gridlock and jump-start reform to improve land conflict resolution.

- This report concludes that an innovative institutional model that addresses these institutional barriers needs to be devised to improve land conflict resolution.

\section{Background}

In Indonesia, few issues are more consequential and controversial than the question of who owns, accesses, and controls land. The nation's economy relies heavily on industries that are land and natural resource intensive (World Bank 2014). Concessions granted to all industrial sectors, including logging, oil palm plantations, and mining corporations reportedly cover more than one-third of its landmass (Abood et al. 2015). However, as mines, oil palm plantations, and cities expand, communities already on the land are being pushed out and are fighting back. Roughly a third of Indonesia's people depend on farming for their livelihoods (BPS 2020b). Unequal distribution of land in Indonesia has long provoked conflicts (Renner 2002). The precise number of land conflicts is unknown (VOA 2018). However, both the government and civil society organizations (CSOs) have reported significant figures (FoE et al. 2008; GoI 2015, 2017; KPA 2019). Indonesia's growing population and ever-increasing demand for land will likely fuel more clashes in the future. Rising consumption, environmental degradation, volatile markets, and competition for scarce natural resources will heighten the risk of land conflicts (Andrews-Speed et al. 2012; Bernauer et al. 2012; Hartmann 2001; PRB 2001; Raleigh and Urdal 2007; Ray and Esteban 2017; Srinivas et al. 2015).

To prevent these problems from spiraling out of control, Indonesia will need to strengthen the institutions that currently allocate, regulate, and adjudicate land conflicts. Without better land governance, conflicts will stymie efforts to manage land and natural resources equitably and sustainably. Recognizing these risks, Indonesia's government has rolled out many initiatives, including the One Map Policy (Kebijakan Satu Peta), the Social Forestry Program (Perhutanan Sosial), and the Agrarian Reform Program (Reforma Agraria). It has created ad hoc institutions to implement these initiatives and has enlisted a variety 
of ministries and agencies with various and sometimes competing jurisdictions. However, land conflicts continue to hurt many. Thus, Indonesia requires stronger institutions to govern land justly and resolve conflicts peacefully.

\section{This report explores the institutional} barriers to land conflict resolution in Indonesia. It focuses on the government's institutional structure and capacity at the national level, leaving aside the courts and regional or local governments. It provides information on the overview of land conflict in Indonesia, the distribution of authority within the national government in land conflict resolution, how it affects the resolution efforts, and other factors that hamper the efforts of national institutions to effectively resolve land conflicts.

\section{This paper is based on an extensive} literature review and qualitative research. The literature review focused on Indonesia's land governance history. We conducted legal and regulatory analysis of Indonesia's prevailing land governance and land conflict policies as well as interviews, focus group discussions, and stakeholder consultations with 47 experts and practitioners from the government, CSOs, research and academic institutions, and the private sector. Data was gathered between September 2018 and February 2019 using open-ended inquiries to unravel experiences, observations, and findings on institutional barriers to land conflict resolution (Table ES-1).
Land governance is the totality of policies, processes, and institutions that manage land, property, and natural resources, including decisions on access to land, land rights, land use, and land development (Enemark 2009). In particular, institutions are the tools and enablers that allow those policies and processes to be implemented (Dasandi et al. 2015; UN DESA 2016). Thus, they define how power is exercised, how decisions are made, and how these decisions are enforced, monitored, and evaluated (Forst 2014).

\section{The history of Indonesian land} governance is long, winding, and remains omnipresent to this day. It began with the Dutch dual land tenure system, which applied Western and customary tenurial arrangements concurrently. Postindependence, the Basic Agrarian Law, aimed at resolving the dualism, converted Western land titles to a national system, recognized customary rights, and established a land reform court. However, under the New Order regime (1966-98), this land reform program was dismantled and replaced by a patronage system that revolved around President Suharto and suppressed land reformers, many of whom were his opponents. Sectoral regulations were introduced, and rapid economic development ensued. Growing evidence indicates that these policies led to inequality (Colmey and Liebhold 1999; Pausacker 2018; Schreiber and Schneider 2017; Shenon 1998), the violent expulsion of local people (Sirait

Table ES-1 | The Number of Resource Persons Based on Background and Resource Methods

\begin{tabular}{|c|c|c|c|c|}
\hline RESOURCE PERSON BACKGROUND & FGD & INTERVIEW & MEETING & TOTAL \\
\hline Academician or expert & 2 & 2 & & 4 \\
\hline CSO representative & 6 & & 9 & 15 \\
\hline Internal WRI Indonesia expert & 13 & & & 13 \\
\hline National-level government official & 2 & 4 & 4 & 10 \\
\hline Private sector representative & 2 & & & 2 \\
\hline Subnational-level government official & 2 & & 1 & 3 \\
\hline Total & 27 & 6 & 14 & 47 \\
\hline
\end{tabular}

Notes: $\mathrm{CSO}$ = civil society organization; FGD = focus group discussion; WRI = World Resources Institute. Source: WRI authors. 
et al. 1999, as mentioned in Wrangham 2002), and allowed land developers to take control of vast estates (Rachman 2011).

The present land governance is an arrangement of decentralized local governments, a complex network of national ministries and agencies, and a patchwork of initiatives. The fall of the New Order regime (1998) led to a surge of agrarian protest, the resurgence of customary communities (Sopian 2015), and an unprepared transition of power from the national to local governments due to the "big bang" decentralization (Kuncoro 2002; Naylor et al. 2019). This unprepared transition has created more problems. The newly given licensing powers have been used by local governments as an easy way to increase their revenue (Arnold 2008; Earth Innovation Institute 2015; Gaveau et al. 2016; Nasution 2016) and by politicians to curry favors with their donors, who provide the needed support to compete in local elections, which have begun to be astronomically expensive (Akhir 2015; FoE et al. 2008; Gecko Project and Mongabay 2017a, 2017b, 2018a, 2018b, 2018c, 2018d, 2018e, 2019a, 2019b; Kiswanto 2017; Kurniawan 2016). Despite the decentralization, the national government still exercises much authority over land governance. However, the national government is not a single, unified, and coherent entity, instead consisting of several authorities with different laws, interests, and objectives.
The current administration, led by President Joko Widodo, has launched numerous initiatives to address land conflicts. However, progress has been underwhelming. Through the Agrarian Reform and Social Forestry Programs, the government aims to redistribute and provide millions of hectares of land to local communities and individuals. However, both programs have yet to meet their targets.

No land sector, region, or stakeholder in Indonesia seems to escape land conflicts. Since 2012, there have been hundreds of land conflict cases recorded annually (Figure ES-1). The Consortium for Agrarian Reform (Konsorsium Pembaruan Agraria), a leading Indonesian CSO focusing on agrarian reform, reports that conflicts occur in forests, on plantations, along coastal or maritime areas, in mining areas, around infrastructure sites, on property, around military facilities, and on farmland (KPA 2019). They occur on oil palm plantations and in conservation areas (GoI 2017a). Land conflicts occur across Kalimantan, Sumatra, and Java (GoI 2015; KPA 2019). They involve conflicts between communities and private corporations, communities and state-owned enterprises, communities and law enforcers, communities and permit holders, different communities, and the various government agencies (GoI 2015; KPA 2019).

Figure ES-1 | The Number of Land Conflicts between 2009 and 2020

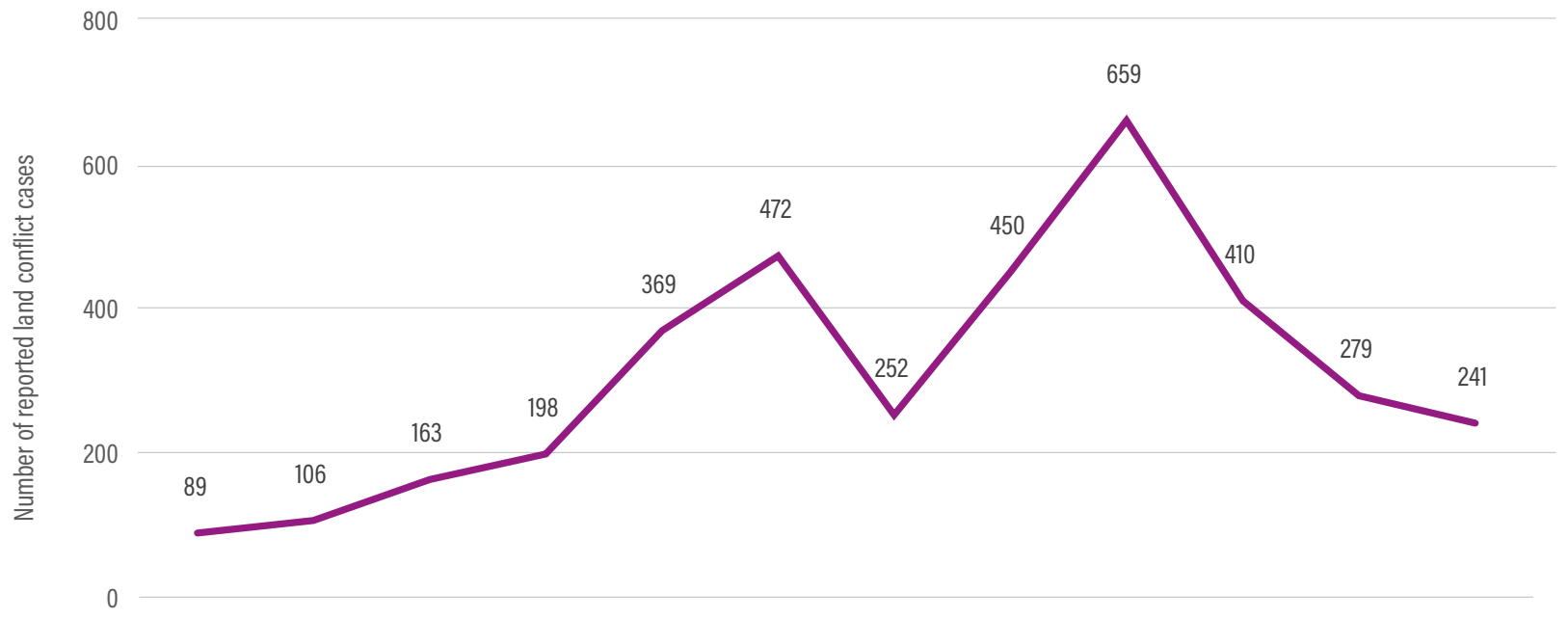




\section{The financial and human costs of land} conflicts are astronomical and significant. They can cause a 29-fold increase in the operational costs of land-based projects (Munden Project 2012), raise annual operational costs by 88 percent, raise investment costs by 117 percent, incur indirect costs of US\$9 million (Barreiro et al. 2016), and delay production worth $\$ 20$ million per week for large-scale mining corporations (Davis and Franks 2014). For communities, land conflicts can result in 35 percent of previously free commodities no longer being free and water supplies being more restricted, forcing households to pay Rp 1.3 million per family per month to access water (Zakaria et al. 2019).

Households are forced to work an additional 35 hours per month to make up for the lost income (Zakaria et al. 2019). Between 2014 and 2020, 1,693 people were arrested without due process, 1,275 were victims of harassment, 92 were shot, and 85 were killed (KPA 2015, 2016, 2017, 2018, 2019, 2020, 2021). Siscawati (2017) reports that land conflicts lead to low educational attainment for girls, the maintenance of underage marriage traditions, and increased human trafficking of women and girls.

\section{Land conflicts in Indonesia are} situated within the context of distrust towards broken-down institutions and mechanisms. Conflict can serve as a necessary part of social change and development (Coser 1957, 198; Ray and Esteban 2017). However, conflicts can become violent and destructive when institutions and mechanisms break down.
This violence erupts when instances of political exclusion, social discrimination, and/or economic marginalization occur as well as when peaceful action is no longer considered a viable means of achieving change (UN Framework Team 2012). We see those instances in Indonesia. Local communities and smallholders have not been prioritized in forestry and plantation sector development (IPAC 2013; Lucas and Warren 2013). Poorly delineated boundaries effectively deny access and rights to local communities (Srinivas et al. 2014; Tjondronegoro 2006), which leads to overlapping claims (Fay and Sirait 2002). Overlapping claims even exist among government agencies (GoI 2017b; Oxford Business Group 2015), and there are land conflicts due to the poor implementation of the government's transmigration program that led poor people to move from densely populated cities/villages to less populated ones (Bachriadi and Wiradi 2014; IPAC 2013).

\section{Key Findings}

Our study found three levels of institutional barriers that significantly impact the operational effectiveness of attempts at resolving land conflicts (Table ES-2).

\section{There is a lack of strategic coherence at the implementation level. Our resource persons indicated that the progress of the Agrarian Reform Program, the Social Forestry Program, the One Map Policy, the Land Tenure Settlement in the Forest Areas Program}

Table ES-2 | Summary of Institutional Barriers Hampering Land Conflict Resolution in Indonesia

\section{\begin{tabular}{l|l} 
LEVEL & INSTITUTIONAL BARRIER
\end{tabular}}

$\begin{array}{ll}\begin{array}{l}\text { Strategies and } \\ \text { institutional }\end{array} & \text { - Utilization of administrative, reactive, and ad hoc approaches to land conflict resolution } \\ \text { framework } & \text { - A complex and scattered set of institutions are unable to coordinate to resolve conflicts effectively }\end{array}$

\section{Operational} framework

\section{- Absence of operational guidelines that operationalize social justice in land conflict resolution and supports cross-institutional coordination \\ - Land and land conflict data and information systems that are inaccurate, not unified, and unofficial \\ - Lack of skilled and trained workers to comprehensively resolve land conflicts and lack of funding}

- Rampant corruption, conflict of interest, and weak law enforcement can trigger and worsen land conflicts and hamper their resolution

- Lack of strong political will and support from the nation's top leaders to push for institutional reform 
(Penyelesaian Penguasaan Tanah dalam Kawasan Hutan; PPTKH), and the Complete Systematic Registration of Land (Pendaftaran Tanah Sistematis Lengkap; PTSL) initiative has not gone as planned. Each program operates under its own corridor, with each agency employing its strategies and priorities. Overall, institutions heavily rely on an administrative approach that focuses on how land rights and licenses meet the requirements of the government's certification or issuance system but fail to address underlying structural problems such as unequal ownership and resource distribution. Furthermore, the approach tends to be reactive and ad hoc, waiting for conflicts to be reported by disputants instead of detecting where the risk of land conflict is high. This lack of coherence between approaches has led to the neglect of the structural problems that underly these conflicts because the programs can only address a part of the conflict.

\section{The institutional arrangements are} complex and scattered. The distribution of authority to resolve land conflicts is scattered, piecemeal, and distributed among numerous institutions. The lack of clarity causes confusion among disputants, exacerbates tensions, and reduces trust (Gumilang 2016). The Ministry of Environment and Forestry (Kementerian Lingkungan Hidup dan Kehutanan; KLHK) and the Ministry of Agrarian and Spatial Planning/ National Land Agency (Kementerian Agraria dan Tata Ruang/Badan Pertanahan Nasional; $\mathrm{BPN}$ ) are authorized to handle complaints and claims regarding land rights or uses in the forest and nonforest areas, respectively. The KLHK also handles conflicts related to environmental services. Also, the Ministry of Agriculture (Kementerian Pertanian; Kementan) facilitates conflict resolution in plantation areas. The Coordinating Ministry for Political, Legal, and Security Affairs (Kementerian Koordinator Bidang Politik, Hukum, dan Keamanan; Kemenko Polhukam) and the Ministry of Home Affairs (Kementerian Dalam Negeri; Kemendagri) manage land conflicts that have evolved into social conflicts. The KLHK's Directorate General of Social Forestry and Environment Partnership (Direktorat Jenderal Perhutanan Sosial dan Kemitraan Lingkungan; Ditjen PSKL) also handles conflicts relating to customary forests. In cases of open conflict, the National Armed Forces (Tentara Nasional Indonesia) and National Police (Kepolisian Negara Republik Indonesia) are involved. When conflicts could lead to social disintegration, Kemendagri and the Ministry of Defense (Kementerian Pertahanan; Kemenhan) become involved. The National Commission for Human Rights (Komisi Nasional Hak Asasi Manusia; Komnas HAM) mediates conflicts with human rights implications, and the Ombudsman is involved for instances of maladministration. Each of the initiatives mentioned previously also adds ad hoc institutions to an already complex and crowded institutional patchwork (see Table ES-3 for the complete picture).

\section{In light of the lack of strategic coherence and complex and scattered institutional arrangement, poor coordination is also prevalent among relevant agencies. We} found little incentive for coordination, even though it is required to resolve land conflicts. The task of interdepartmental collaboration is considered cumbersome and time-consuming. Even within institutions, directorates are divided, hampering land conflict resolution. In terms of regulations, the Management of Social Conflict Act No. 7 of 2012 only provides minimal circumstances (when violent social conflict is ongoing) for cross-institutional collaboration. The implementation of various programs and initiatives is siloed and lacks effective coordination.

The absence of operational guidelines that provide a clear procedure for coordinating and implementing social justice values hamper effective resolution. The initiatives are not equipped with an operational mechanism to guide ministries and agencies on exercising their authority or collaborating to resolve conflicts, including how to cover the site-level and national-level decision-making. The absence of guidelines also pertains to operationalizing social justice values, access to the national level, and addressing the asymmetry of power between various stakeholders where the community is often the weakest. Thus, administrative approaches often take precedence, which typically disadvantages communities due to the lack of formal recognition or administrative proof.

\footnotetext{
Furthermore, in terms of operational structures, land information and conflict data systems are lacking. Indonesia remains without a unified, complete land conflict data collection system. Attempts have been made by the One Map Policy and nongovernmental
} 


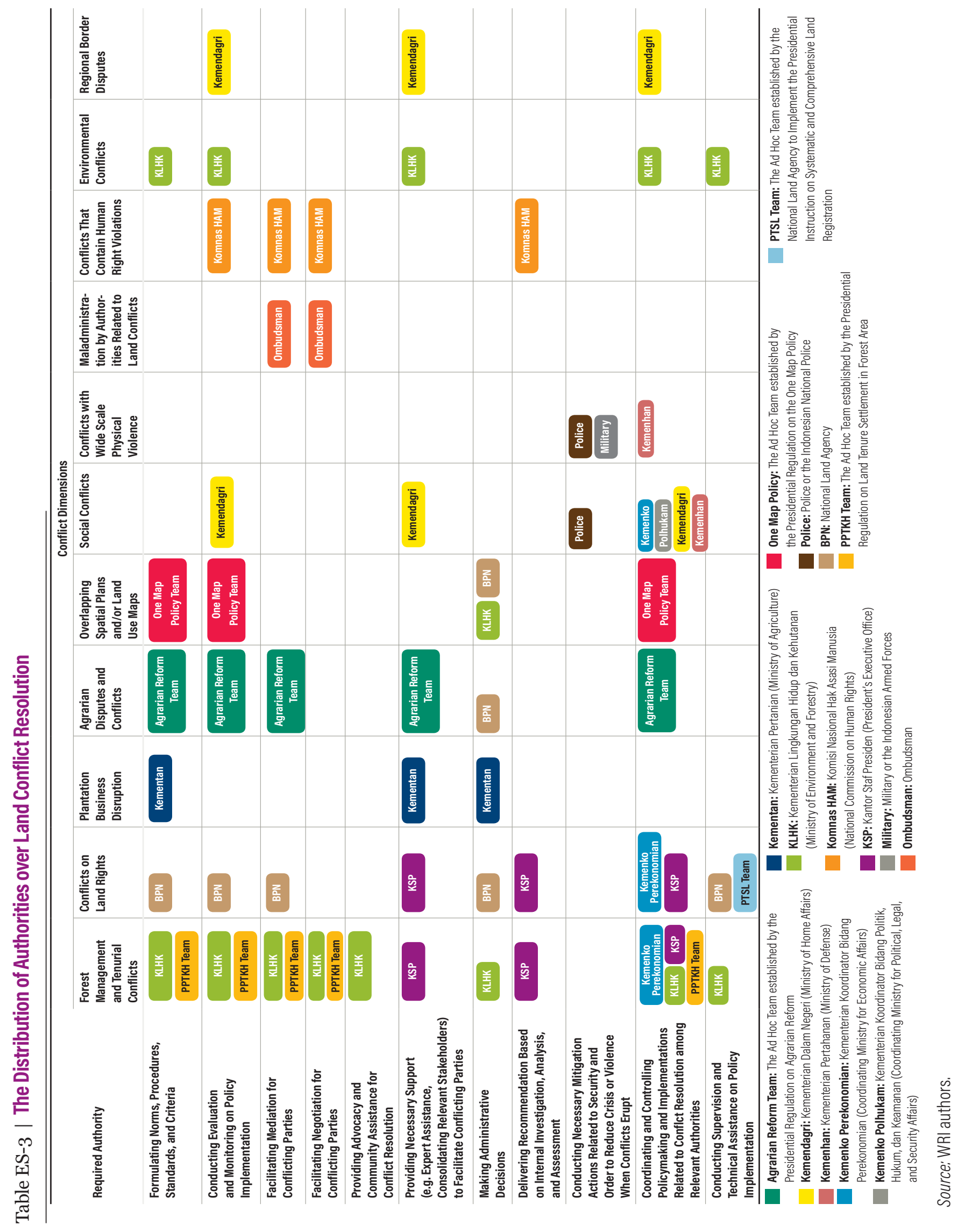




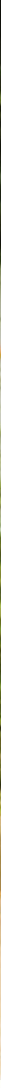

Conflicts of interest are apparent because the institutions tasked with resolving land conflicts are the same agencies that enacted the policies, land rights, and licenses that caused those conflicts in the first place. Our resource persons wondered whether those institutions could sufficiently resolve conflicts. At the same time, others shared that the institutions are under stress of being unfairly prosecuted for maladministration if their resolution interferes with powerful people. The lack of enforcement towards noncompliant license holders is also a significant problem that drives land conflicts and perpetuates injustice.

\section{Land reform and conflict resolution will} require political will. These problems have political dimensions, that the bureaucracy alone cannot address. Our resource persons testified that their performance relies on support from high-level leaders, including the ministers and the president. Strengthening policies and reforms will require strong political will and leadership (Burns 2007). Resolving land conflicts will require strong leadership to mobilize institutions and resources to tackle the root causes of land conflicts (Srinivas et al. 2015).

\section{Conclusion and Recommendations for Further Research}

\section{Existing efforts at the national level} have fallen far short of what is needed. They remain reactive, spread across various institutions, and have so far failed to address the underlying social and economic vulnerabilities that produce these conflicts. The complex and scattered arrangement of authorities, compounded by a lack of coherence, coordination, and collaboration, result in insufficient institutional capacity. Poor operational structures and a lack of data management systems further complicate this picture. Corruption, conflicts of interest, and the lack of robust and legitimate leadership and support will continue to hamper reform and progress.

This paper identifies various areas for further research to develop an effective institutional arrangement for land conflict resolution. Research is needed on how Indonesia can build the political will and support required to reform land governance, develop a coherent conflict resolution strategy, build coordination mechanisms, and integrate land conflict data management systems. Further investigation can also point to strategies for leveraging and consolidating resources and creating robust safeguards to mitigate conflicts of interest and corruption. 



\section{INTRODUCTION}

Land conflicts are daunting problems that have persisted for decades in Indonesia, requiring considerable government efforts to resolve and prevent. This report assesses the institutional problems hampering the government's efforts in resolving land conflicts. It is based on qualitative data gathered from 47 people, an extensive regulatory analysis of prevailing laws, and a literature review. The findings presented here will form the basis for research to develop an institutional approach that can effectively resolve land conflicts in Indonesia. 
In Indonesia, vexing questions and controversies over how land is governed have far-reaching consequences. The country's economic growth relies mainly on the cultivation and extraction of natural resources, with agriculture, forestry, and mining contributing approximately 25 percent of Indonesia's gross domestic product (GDP) and 30 percent of the government's budget revenues (World Bank 2014). Over one-third of the country is designated as an area of industrial concessions, which includes oil palm and mining (Abood et al. 2015). Unfortunately, according to Andrews-Speed et al. (2012), accelerating demands for natural resources, increasing market volatility, and resource scarcity will exacerbate the challenges and complexities of determining who uses land and natural resources. It is likely to heighten vulnerabilities, fuel grievances, and spark conflicts. Environmental degradation, population growth pressure, and rising consumption amplify these problems (Bernauer et al. 2012; Hartmann 2001; PRB 2001; Raleigh and Urdal 2007; Ray and Esteban 2017). Between 1960 and 2013, the total land under cultivation in Indonesia rose by about 2 percent annually, and urbanization has also created a stronger push for rapid land conversion (Srinivas et al. 2015).
Farmers, who make up a third of the labor force (BPS 2020b), already feel the squeeze where they control on average only 0.8 hectares (ha) of land, far below rates in neighboring Thailand (3.2 ha per farmer) and the Philippines (2 ha per farmer) (Zuhra 2017). With increasing demand and only a constant supply-and compounded by insecure tenure and an increasing demand for large-scale investment-smallholders will likely lose out. This situation means that land is a very contentious socioeconomic subject in Indonesia.

For decades, Indonesians have struggled to resolve a fundamental question: who owns, accesses, and controls land? This unresolved question has been with the nation since its inception in 1945 and continues to the present. Along with it comes a steady, unrelenting number of conflicts that no actor in Indonesia seems able to escape. The Consortium for Agrarian Reform (Konsorsium Pembaruan Agraria; KPA), a leading Indonesian civil society organization (CSO) focusing on agrarian reform, reports a steady increase in land conflicts from 2009 to 2017 (Figure 1). Although reported land conflicts have fallen, the number remains high. The Jakarta Post (2019) reports that in 2018, land

Figure 1 | The Number of Land Conflicts between 2009 and 2020

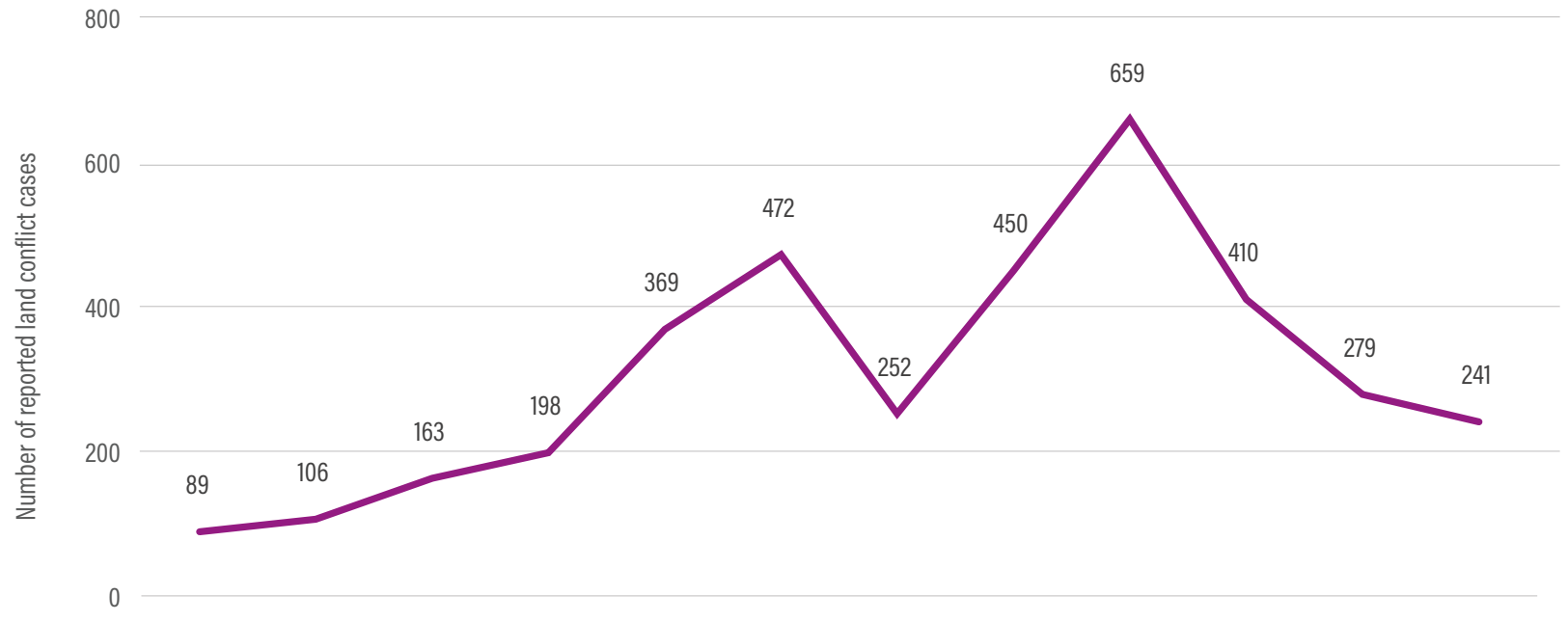


conflicts involved approximately 807,000 ha of land and affected more than 87,658 households. The National Commission on Human Rights (Komisi Nasional Hak Asasi Manusia; Komnas HAM) records that the total area of land subject to conflicts is approximately 2.7 million ha, an area 35 times the size of New York City (Nugraha 2019). In 2008, Sawit Watch monitored 513 cases of conflict between communities and companies (FoE et al. 2008). Furthermore, the severity of the problem is highlighted because many of the reported land conflicts involved human rights violations (GoI 2019a). Moreover, these figures almost certainly understate the magnitude or seriousness of land conflicts in the country. As reported by the Voice of America (2018), many land conflict incidences in Indonesia go unreported, and the available data is scattered. Beyond any doubt, clashes over land are persistent and widespread.

\section{Research Objectives}

Unless dealt with, land conflicts will continue to hamper Indonesia's ability to manage land and resources sustainably and equitably. Mitigating, dealing with, and resolving land conflicts is a daunting problem that needs a concerted government effort. Thus, this report focuses on the Indonesian government's institutional structure and capacity to address land conflicts. It covers land governance, policies, administration, and institutions at the national level. The role of the subnational government, the courts, and in-court dispute settlement mechanisms are not addressed. Our research assesses and highlights

- the state of land conflict resolution in Indonesia;

- the distribution of authority among multiple institutions and how this affects the resolution of land conflicts; and

- other factors hamper the national government's efforts to resolve land conflicts effectively.

This report, assessing existing institutional problems, will be the first in a series of research. A following paper will explore ways to build institutions capable of effectively resolving land conflicts in Indonesia by investigating the key elements of an effective institutional arrangement for land conflict resolution and proposing a model that will meet the needs and overcome the obstacles identified in this study. This work will also point to fruitful areas for further research.

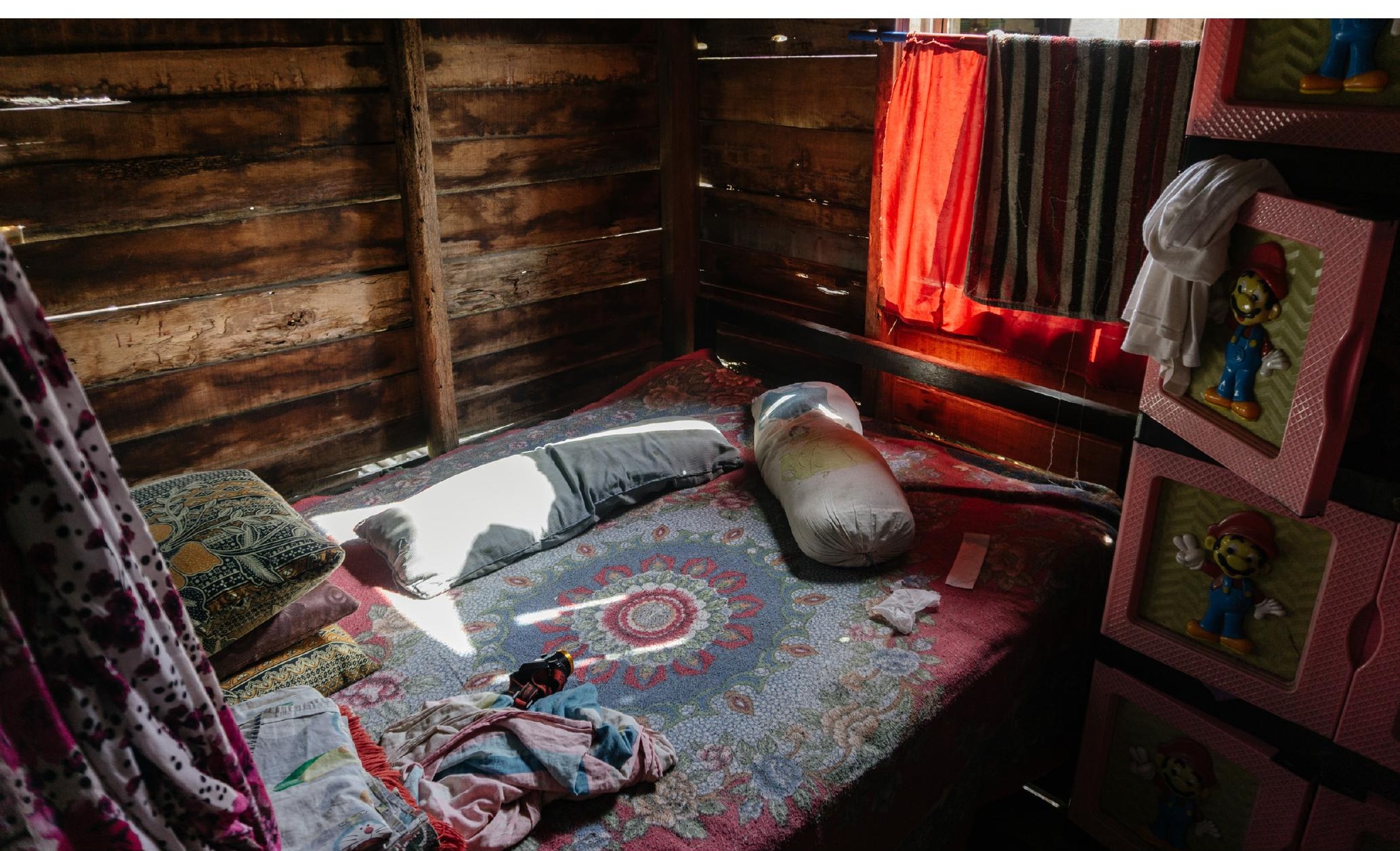


(1)

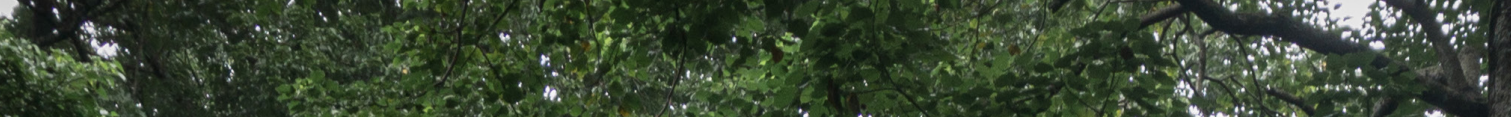

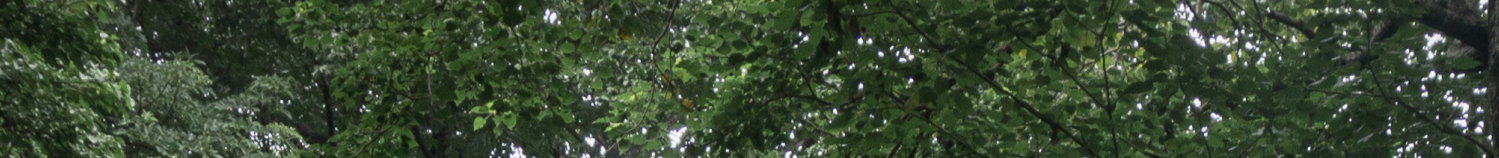

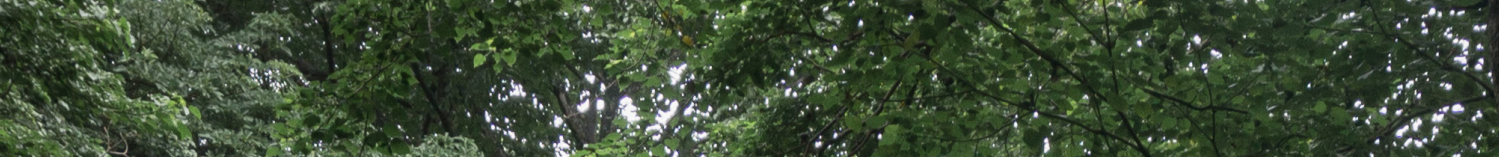

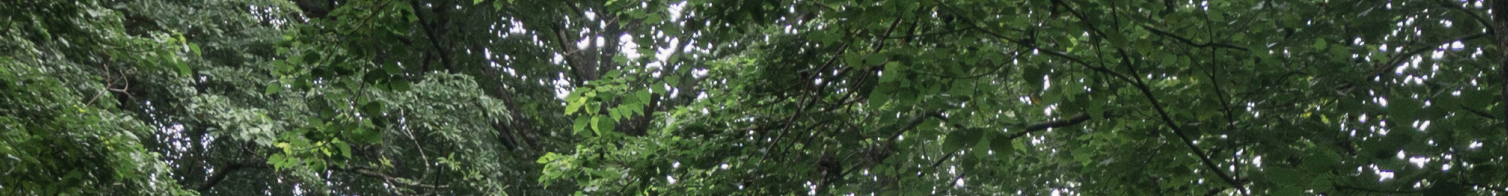

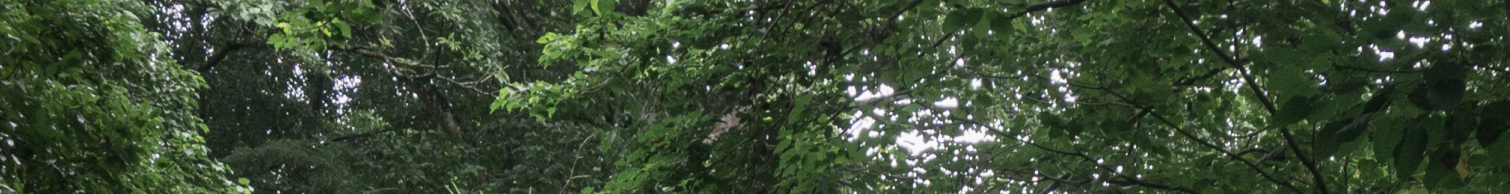

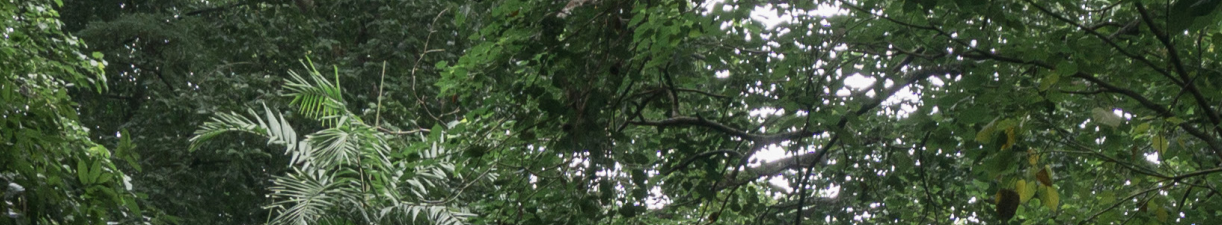

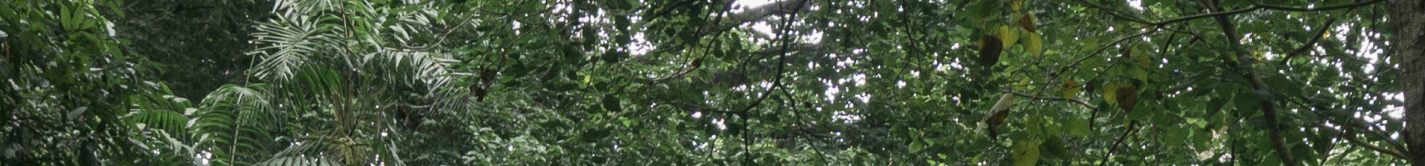

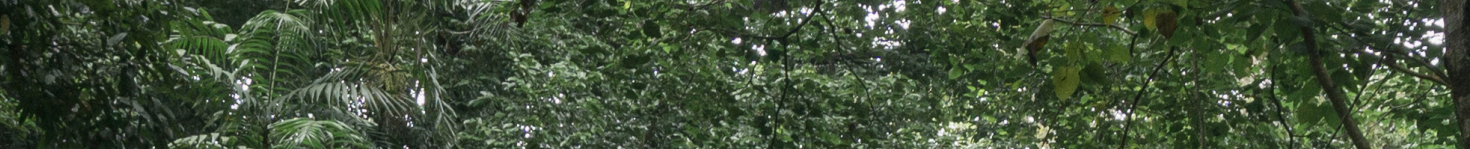

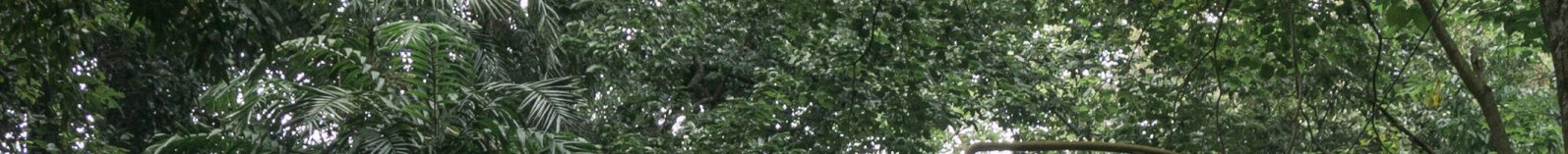

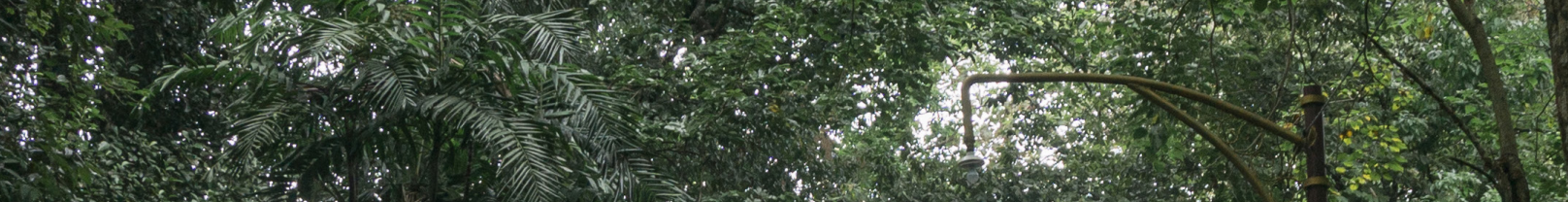

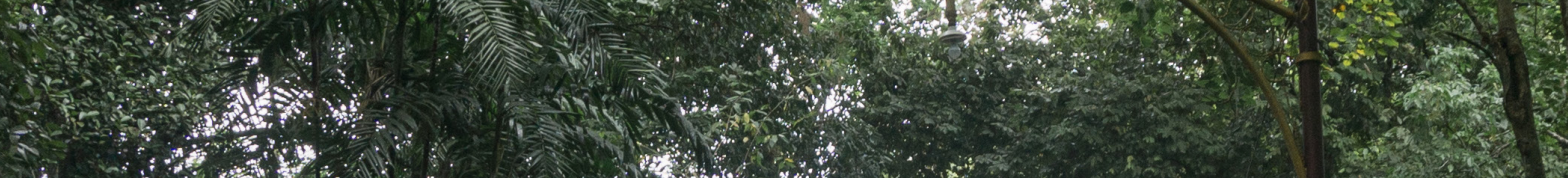

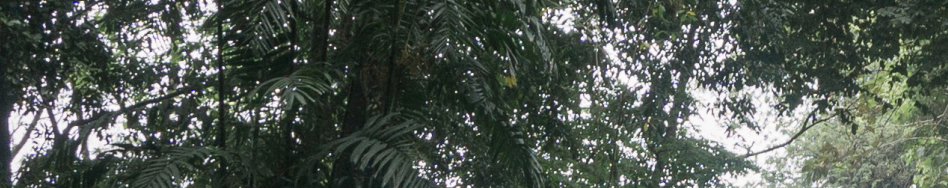
28:

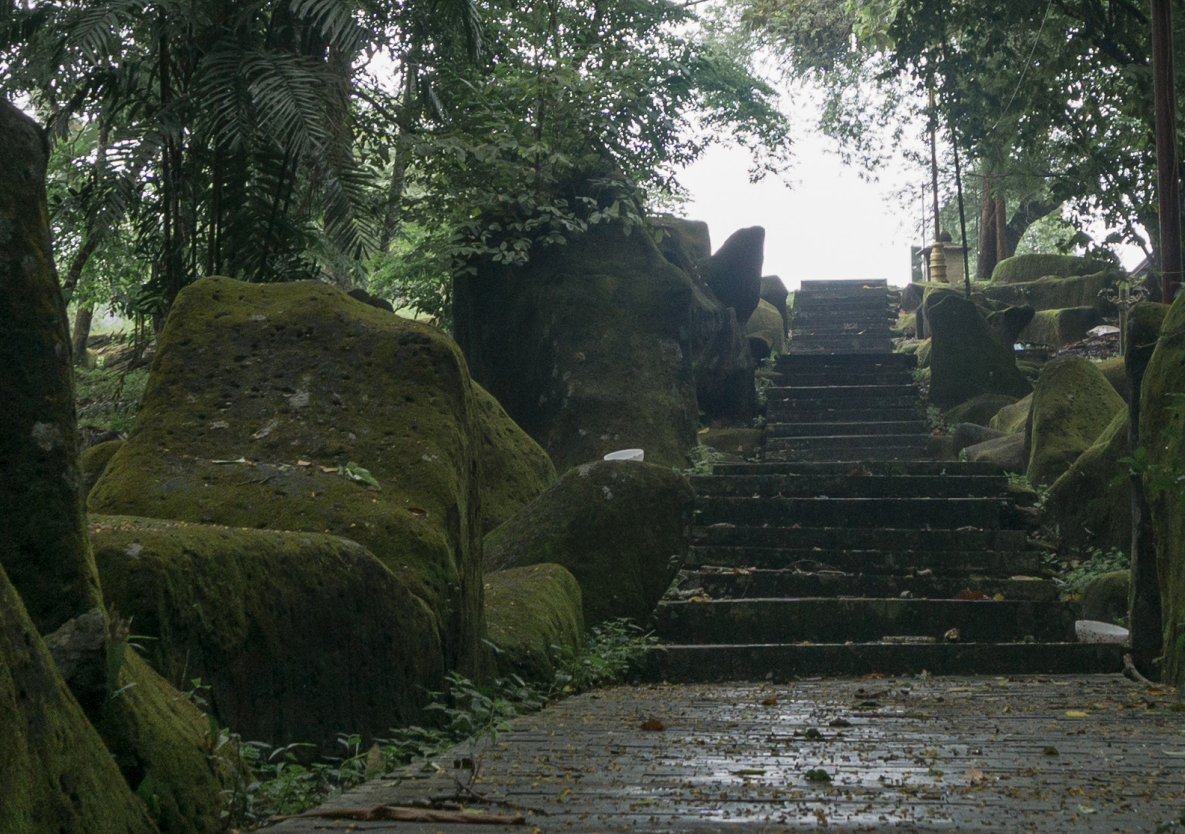

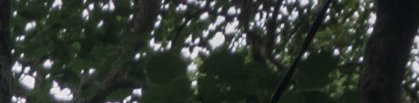
$x^{2}$

4

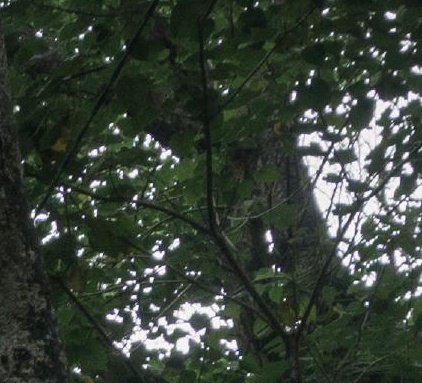

2.:-

$10 \sin 20$

$E=x_{2}=2$

(3)

a) +2 ?

(1) 1.2

ty

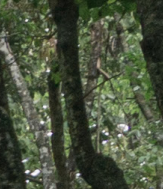

(3) 


\section{UNDERSTANDING LAND CONFLICTS IN INDONESIA}

This section strings together the land governance issues at the root of land conflicts in Indonesia starting from the colonial era to the present day. It demonstrates the iniquitousness of land conflicts as they touch every stakeholder, sector, and region in Indonesia. It describes the current state of land conflicts and highlights the astronomical damages land conflicts have inflict on society's economic and social well-being. 


\section{Land Governance and Institutions in Indonesia}

Like Enemark (2009), we define land governance as the totality of the policies, processes, and institutions by which land, property, and natural resources are managed. Land governance includes decisions on access to land, land rights, land use, and land development. Following this definition, land governance concerns both processes and outcomes and deals with how those decisions are made and how conflicts of interest might be resolved. Within such governance, institutions are the tools or enablers for implementing the policies and processes to achieve designated outcomes, including shared norms and values, laws, and regulations (Dasandi et al. 2015; UN DESA 2016). Institutions define how power is exercised, how decisions are made, and how these decisions are enforced, monitored, and evaluated (Forst 2014).

\section{Postindependence Attempts to Overcome the Colonial Dual System of Land Tenure}

In Indonesia, land governance is shaped by sociopolitical and economic structures, cemented through policies and institutions, that can be traced back to the Dutch colonial system. During the Dutch colonial period (the 1600s-1940s), a dual system of land tenure in Indonesia applied both Western tenurial arrangements (introduced by the Dutch) and older, customary (adat) tenurial arrangements concurrently. Adat arrangements developed under a community's long-term practices reflect cultural or religious beliefs and values and usually embrace collective ownership.

Postindependence, the 1945 Constitution stated that natural resources, including land, are ruled, managed, and controlled by the Government of Indonesia, meaning for its people's welfare. This principle was then followed by the Basic Agrarian Law (Law No. 5 of 1960; BAL), which aimed to resolve the problems created by this dualism. BAL was intended to be an overarching law governing all agrarian matters in Indonesia. Under BAL, all Western land titles would be converted into a new national system. The adat rights would be recognized as long as they did not conflict with the national interest. At least during its inception, this law recognized the social function of land and natural resources, including the importance of equity. The

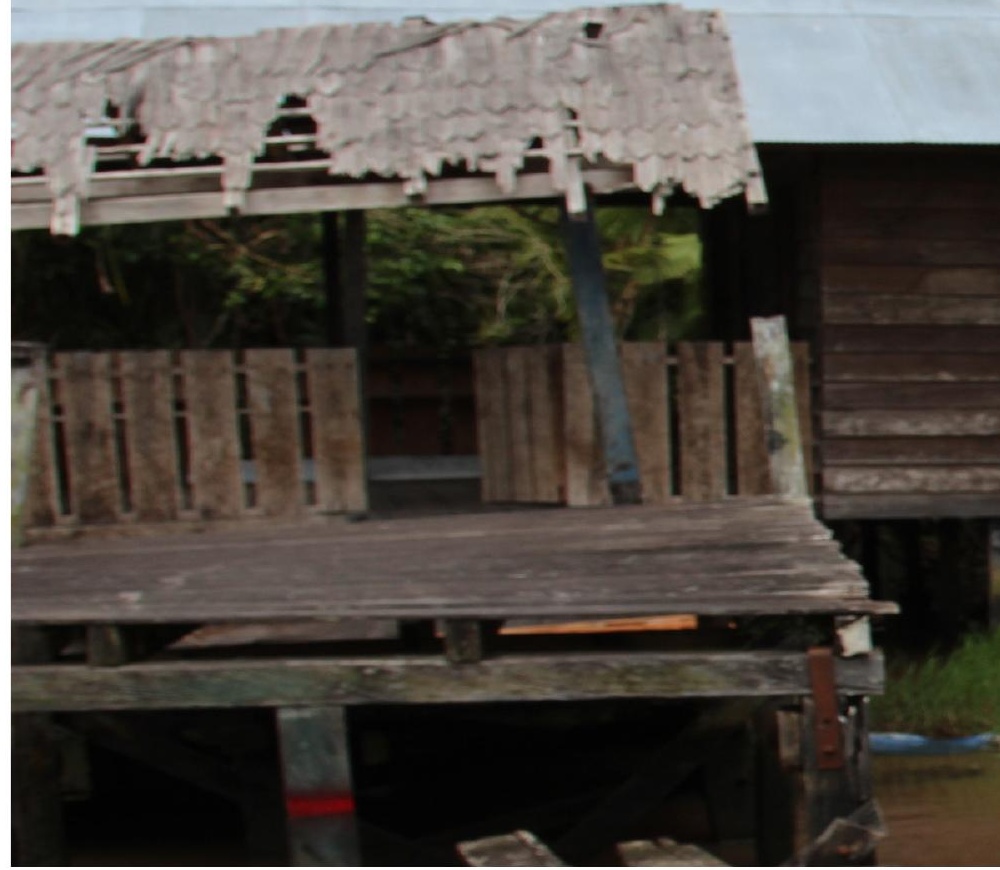

government at that time, under President

Sukarno, promoted a narrative based around equality that put the people first (Sopian 2014). To showcase this commitment, the government even established a land reform court in 1964 to adjudicate civil, private, and administrative cases related to implementing this land reform.

\section{President Suharto Reverses Land Reform Progress}

In 1966, the New Order regime of President Suharto began and was not too kind to land reformers. Studies show that Suharto suppressed his political opponents, many of whom were advocates of land reform, hunted them down, and killed large numbers to solidify the regime's rise to power (Adam 2015; McGregor 2009; Pelzer 1982). Maxton-Lee (2020) reports that the New Order regime used land to cement a patronage system revolving around Suharto, creating incentives for economic and political elites to remain loyal and maintain the status quo. Whereas the powerful had access to Suharto's patronage, peasants and farmers found their hold on land slipping away. As Sopian (2014) has explained, this patronage system gave the regime the upper hand when it felt the need to exercise or showcase its power and appropriate and parcel out land.

Despite seeking to fundamentally contradict BAL's equity and integration principles, the New Order regime decided to keep BAL. The weakly defined state land and national interest concepts in BAL were stretched and repurposed to legitimize state policies, such as land appropriation. Research shows that in the 




absence of limitations on land redistribution and ownership, the regime used BAL to accelerate and cement inequality in landownership (Colmey and Liebhold 1999; Pausacker 2018; Schreiber and Schneider 2017; Shenon 1998). This insecure land tenure situation made peasants and farmers increasingly vulnerable to exploitation and eviction. According to Sirait et al. (1999), as mentioned in Wrangham (2002), the New Order regime frequently sought to remove local people from state land, often using violence.

The New Order regime then created new laws and bureaucratic structures that undermined the idea of having an integrated agrarian law. In 1967, the New Order regime established the Basic Forestry Law (Law No. 5 of 1967) and the Basic Mining Law (Law No. 11 of 1967). The Basic Forestry Law demarcated a new area of land governance: the forest area. As a result, Indonesia's land titling system has mainly been divided into forest and nonforest areas, with each being administered by a different authority. Forest areas are designated as permanent forests, whereas nonforest areas are designated for nonforestry development. Meanwhile, in parallel to this, the Basic Mining Law created a land management system for mining. Land governance thus became more complex. The sectoral regulations then proceeded to further violate BAL's original aim of a more integrated approach to land management (Lucas and Warren 2013, 8-9). Lastly, in 1970, the regime abolished the land reform court, declaring that its nationalist, religious, and communist approaches were not compatible with the New Order regime's policy direction. ${ }^{3}$

\section{Suharto Repurposes Land for Economic Development}

The regime's approach to tenure depended on whatever served its interests. During the 1970s, when the focus shifted from consolidating power to economic development, secure tenure was deemed necessary to spur business and investment (Srinivas et al. 2014). Rapid economic development and self-sufficiency were the regime's main narratives (Lucas and Warren 2013, 5). In 1988, the government established the National Land Agency (Badan Pertanahan Nasional; BPN) as a centralized land administration body. According to Rachman (2012) and Schreiber and Schneider (2017), the BPN was created to solve problems related to land in ways that would foster economic development. Rachman (2011) reports that from 1969 to $1982,1.5$ million ha were released for development projects and further accelerated in 1993-98, with 9.6 million ha of land being released to land developers for the purposes of industrial parks, housing, agriculture, and others.

Further, the government promoted a transmigration program that effectively led poor people to leave their ancestral lands. It was ostensibly aimed at reducing the population density in Java and boosting agricultural productivity. Instead, it created more problems, such as conflicts between migrants and local communities, who competed for land and resources, and between migrants and the landrelated authorities, who often failed to provide the migrants with sufficient land for cultivation (Bachriadi and Wiradi 2014). The ramifications of this migration are still evident today. 


\section{An Unprepared Transition to Decentralization Fractures Authorities}

The fall of the New Order regime in 1998 unleashed a surge of agrarian protests and the resurgence of adat communities (Sopian 2015). The national government enacted a decentralization process in 1999 to respond to the demand to bring government "closer" to the people, increase cohesion, and bolster citizen participation (Kuncoro 2002). This period has often been characterized as the "big bang" of decentralization. Authorities and functions were abruptly transferred from the national level to the local level. This devolution and concentration of power at the local level required proper transition mechanisms and sufficient systemic institutional capacity, including robust coordination mechanisms among local institutions and the national government. However, given the "big bang" nature of this decentralization, these systems and capacities were not put in place. This process was marked by power struggles between the various government tiers, including those with authority over land management.

Some powers related to land governance, such as spatial planning and the licensing of businesses (including mining and plantations), were delegated to local governments. However, although local governments can now legally issue many types of licenses, primary authority over land titling (ownership) is still vested in the national government. It holds this power in both forest and nonforest areas. The KLHK has full authority over forest areas, including the power to design, delineate, issue licenses, and enforce the law. The BPN has the authority to administer land rights over nonforest areas. This authority includes certifying land rights and control over nonforest areas. Mining zones and the national spatial plan also fall under the authority of the ministry. These zones and plans serve as the legal reference point for provincial and district governments in designating spatial plans and mining zones. These designated spatial plans and mining zones serve as the legal reference to certify land titles and issue licenses.
Furthermore, control over policymaking is further divided between national and local authorities. Local governments exercising their authority must follow land management policies that align with national policies. In contrast, local governments can only provide input to be considered in policymaking and implementation. The national government also has the authority to supervise and monitor how local governments manage land. Therefore, despite decentralization, the national government still holds significant power over land governance (see Table 2).

What may seem like a workable system on paper is challenging to implement in practice. It is not clear how each local and national institution is supposed to execute its authority jointly with others or use the regulations it enforces to address deep, systemic, and unresolved socioeconomic problems. This arrangement leads to disjointed and corrupt land governance that is neither transparent nor fair.

\section{Local Governments Spur a Scramble for Land}

Compounding their troubles, local governments attempting to manage land have been starved for cash. Decentralization devolved responsibilities but not the capacity to generate revenue.

Research by Nasution (2016) found that although local governments have been given more resources to exercise their increased authority, their freedom to collect money, including through taxes, remains limited, as does their power to borrow. According to Arnold (2008), this scant revenue-generating power has induced many local governments to issue plantation permits, mainly for oil palm, because it is the best or only way to collect money. The promise of this additional income from oil palm plantations has encouraged newly empowered mayors to exercise their power to issue licenses. Giving out licenses to mine, cut timber, and cultivate oil palms became a quick way for a local government to cash in on its new power. With very little oversight, a mayor could issue licenses for 1,000 ha at a time to anyone. Research finds that they often do this, ignoring the communities' rights and demands. This situation has produced a patchwork of overlapping permits and land rights, especially between local communities, which often lack administrative land titles, and newcomers who have paid for licenses (Earth Innovation Institute 2015; Gaveau et al. 2016). 
Table 2 | The Distribution of Power between the National and Local Government in Land Management

\begin{tabular}{|c|c|c|c|}
\hline Authority & National Level & Provincial Level & Regency/City Level \\
\hline $\begin{array}{l}\text { Forest } \\
\text { management }\end{array}$ & Stipulates and manages forest areas & $\mathrm{n} / \mathrm{a}$ & $\mathrm{n} / \mathrm{a}$ \\
\hline Land titling & $\begin{array}{l}\text { Grants and controls land titles and } \\
\text { land registration }\end{array}$ & $\mathrm{n} / \mathrm{a}$ & $\mathrm{n} / \mathrm{a}$ \\
\hline $\begin{array}{l}\text { Oil and gas } \\
\text { licensing, } \\
\text { geothermal } \\
\text { licensing, and } \\
\text { small island } \\
\text { and coastal } \\
\text { area utilization } \\
\text { licensing }\end{array}$ & $\begin{array}{l}\text { Grants and controls oil and gas } \\
\text { licenses, geothermal licenses, } \\
\text { and small island and coastal area } \\
\text { utilization licenses }\end{array}$ & $\mathrm{n} / \mathrm{a}$ & $\mathrm{n} / \mathrm{a}$ \\
\hline $\begin{array}{l}\text { Land projects } \\
\text { for the public } \\
\text { interest }\end{array}$ & $\begin{array}{l}\text { Procures land for the public interest at } \\
\text { the national scale }\end{array}$ & $\begin{array}{l}\text { Stipulates location for land-related } \\
\text { projects for the public interest }\end{array}$ & $\mathrm{n} / \mathrm{a}$ \\
\hline $\begin{array}{l}\text { Mining business } \\
\text { licensing }\end{array}$ & Grants mining business licenses & $\begin{array}{l}\text { Grants mining licenses to } \\
\text { communities if delegated by the } \\
\text { national government }\end{array}$ & $\mathrm{n} / \mathrm{a}$ \\
\hline $\begin{array}{l}\text { Spatial plans and } \\
\text { other areas }\end{array}$ & $\begin{array}{l}\text { Stipulates the national spatial plan, } \\
\text { mining areas, commercial mining } \\
\text { areas, state reserve areas, and } \\
\text { geothermal working areas }\end{array}$ & $\begin{array}{l}\text { Stipulates the provincial spatial plan } \\
\text { and community mining areas }\end{array}$ & $\begin{array}{l}\text { Stipulates the regency/city } \\
\text { spatial plan }\end{array}$ \\
\hline $\begin{array}{l}\text { Location permits, } \\
\text { plantation } \\
\text { licensing, } \\
\text { agricultural } \\
\text { licensing, and } \\
\text { direct geothermal } \\
\text { utilization } \\
\text { licensing }\end{array}$ & $\begin{array}{l}\text { Grants and controls location permits, } \\
\text { agricultural licenses, and direct } \\
\text { geothermal utilization licenses across } \\
\text { provinces }\end{array}$ & $\begin{array}{l}\text { Grants and controls location } \\
\text { permits, agricultural licenses, direct } \\
\text { geothermal utilization licenses } \\
\text { located across regencies/cities } \\
\text { within a single province }\end{array}$ & $\begin{array}{l}\text { Grants and controls plantation } \\
\text { licenses, location permits, } \\
\text { direct geothermal utilization } \\
\text { licenses located within a } \\
\text { single regency/city }\end{array}$ \\
\hline $\begin{array}{l}\text { Land conflict } \\
\text { resolution }\end{array}$ & $\begin{array}{l}\text { Resolves conflicts in arable/cultivated } \\
\text { lands that are located across } \\
\text { provinces }\end{array}$ & $\begin{array}{l}\text { Resolves conflicts in arable/ } \\
\text { cultivated lands and untapped lands } \\
\text { located across regencies/cities } \\
\text { within a single province }\end{array}$ & $\begin{array}{l}\text { Resolves land conflicts } \\
\text { in arable/cultivated and } \\
\text { untapped lands located within } \\
\text { a single regency/city }\end{array}$ \\
\hline Customary lands & $\mathrm{n} / \mathrm{a}$ & $\begin{array}{l}\text { Stipulates customary lands (tanah } \\
\text { ulayat) that are located across } \\
\text { regencies/cities within a single } \\
\text { province }\end{array}$ & $\begin{array}{l}\text { Stipulates customary lands } \\
\text { (tanah ulayat) that are located } \\
\text { within a single regency/city }\end{array}$ \\
\hline $\begin{array}{l}\text { Land-clearing } \\
\text { licensing }\end{array}$ & $\mathrm{n} / \mathrm{a}$ & $\mathrm{n} / \mathrm{a}$ & $\begin{array}{l}\text { Grants land-clearing licenses } \\
\text { to individuals/legal entities to } \\
\text { utilize small-scale state land }\end{array}$ \\
\hline
\end{tabular}

Source: WRI authors.

Furthermore, the Indonesia for Sale investigative series by the Gecko Project and Mongabay (2017a, 2017b, 2018a, 2018b, 2018c, 2018d, 2018e, 2019a, 2019b) found that a complex system of political dealings and corruption has resulted in community land being transferred to corporations, often without fair compensation and with police and military forces suppressing resistance. As Kiswanto (2017) has suggested, another unintended consequence of Indonesia's decentralization has been the rise in corruption. Permit issuance has been influenced by vote buying and bribery. Under decentralization, local leaders, including governors and mayors, are elected through the direct local election. The cost of standing in an election in Indonesia has become astronomical, and only those with the wealthiest backers can hope to prevail (Akhir 2015; Gecko Project and Mongabay 2018a, 2018c). One way to finance a campaign is to 
promise policy favors, including licenses, to backers. Many local officeholders stand accused of widespread corruption in doling out licenses (Kurniawan 2016; Gecko Project and Mongabay 2019b) that, in many cases, led to environmental damage and conflicts (Gecko Project and Mongabay, 2018c).

This unstable and poorly built decentralization was no match for the oil palm boom that followed (Naylor et al. 2019) and the land conflicts it unleashed (KPA 2019). This situation allowed oil palm plantations to engulf an additional 1.3 million ha of land between 2006 and 2008 (FoE et al. 2008). By 2019, these plantations had swallowed up 14.6 million ha-an area larger than the entire state of New York (BPS 2020a; Figure 2). Komnas HAM (GoI 2017a) further reports this sharp and steady increase in the land area being licensed to oil palm plantations are inciting conflicts across the country.

\section{Modest Steps Are Under Way, but Much More Work Remains}

Since his election in 2014, President Joko Widodo has sought to promote land equity and better land governance by prioritizing land reform (Kurniawan 2014). This mission began by implementing the Agrarian Reform and Social Forestry Programs in the National Mid-Term Development Plan 2015-2019 (GoI 2014), and it continues to this day. As part of this plan, the Agrarian Reform Program aims to distribute 9 million ha of land to peasants. In comparison, the Social Forestry Program aims to provide 12.7 million ha of land for community-based forest management. The Agrarian Reform program provides guidelines and rules for restructuring landownership and land use in nonforest areas. It aims to promote equal land distribution for all people, primarily focusing on vulnerable populations. To support this, Presidential Instruction No. 2 of 2018 provides direction for the Complete Systematic Registration of Land (Pendaftaran Tanah Sistematis Lengkap; PTSL) initiative across Indonesia. Starting in 2018, the initiative began accelerating land registration in nonforest areas. The Social Forestry Program is intended to offer an opportunity for conflict resolution in forest areas. It allows communitybased forest management in forest areas under a licensing system that recognizes customary rights. The president also issued Presidential Regulation No. 88 of 2017 on the Land Tenure Settlement in the Forest Areas. This law covers options for conflict resolution settlements in forest areas, including those under the Social Forestry Program. Together, these two schemes are designed to oversee land reform, both in the forest and nonforest areas. The president's One Map Policy targets another critical challenge: the lack of coherent, accurate maps (Regulation No. 9 of 2016). The One Map Policy aims to deliver one integrated and standardized geospatial database that should settle most land-use map overlaps. These new policies and regulations are indeed

Figure 2 | The Total Oil Palm Plantation Area from 2015 to 2019

20

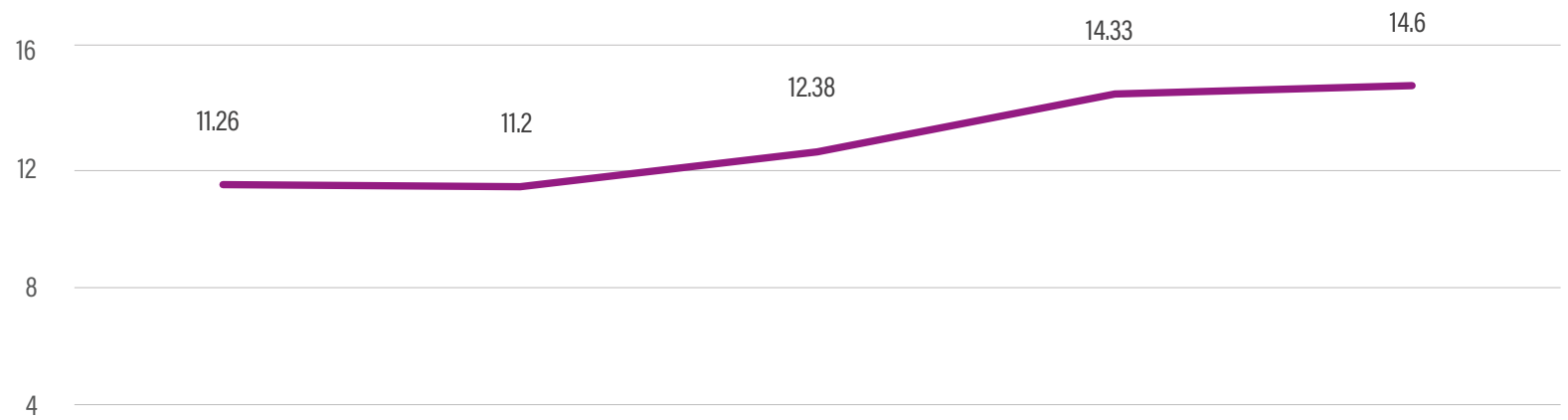

0

$\begin{array}{llll}2015 & 2016 & 2017 & 2018\end{array}$




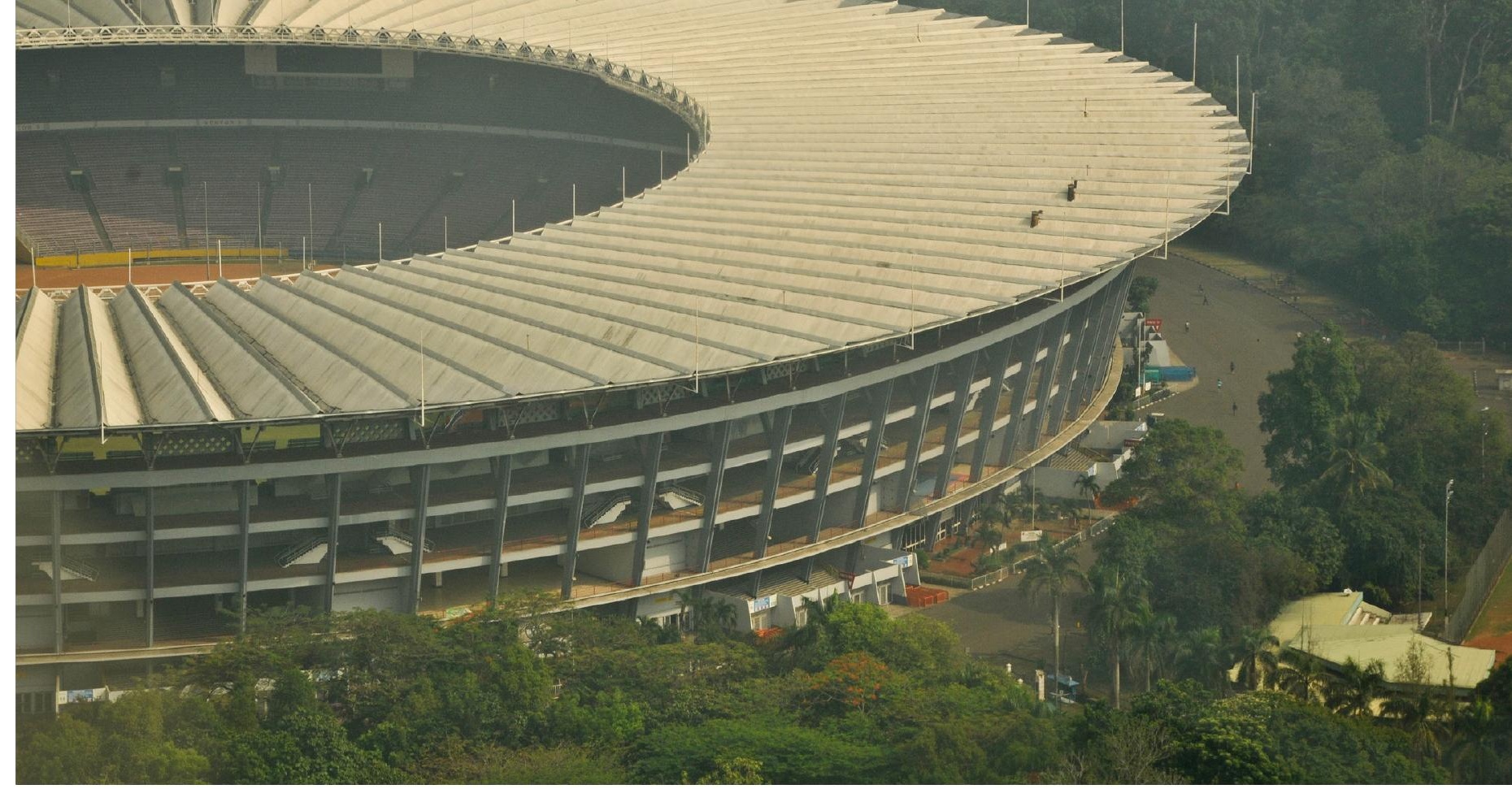

a promising tool for resolving land conflicts in Indonesia. They seek to confront the inequality in land distribution that has been the root cause of conflict.

However, neither the Agrarian Reform nor the Social Forestry Program has come close to meeting the government's targets. Pattiro (2019) reports that the Social Forestry Program has distributed social forestry licenses and confirmed customary forest rights for only around 2 million ha out of the 12.7 million ha it targeted - in other words, only 20 percent of what it set out to achieve by the midterm period in April 2019. Similarly, the Agrarian Reform Program accomplished less than half (45 percent) of what it planned to, addressing land distribution in only around 4 million ha out of 9 million ha targeted, based on the BPN's own 2019 figures (GoI 2020a). And even then, activists note that the majority of the distributed land is not in conflict areas and is only on paper, having not yet been directly distributed to communities on the ground (Thea 2020).

\section{The State of Land Conflict in Indonesia}

\section{Exclusionary Delineation of Areas Is a Structural Problem for Land Conflicts}

Contrary to popular belief, conflict can spur needed social change and development (Coser 1957, 198; Ray and Esteban 2017). However, it becomes problematic when institutions and mechanisms break down, and under such a scenario, conflict often turns violent. In land conflicts, violence is often linked to political exclusion, social discrimination, and/ or economic marginalization. It erupts when peaceful action is no longer considered a viable means of achieving change (UN Framework Team 2012). In other words, conflict is more likely to manifest as violence when individuals or groups lose trust in the ability of government structures and institutions to manage clashing interests and goals.

Unfortunately, land governance in Indonesia is mired in just such a state of affairs. Land conflicts emerge from land governance problems deeply rooted in Indonesia's history, mainly with episodes of local communities and smallholders being excluded (IPAC 2013; Lucas and Warren 2013, 11). Land can contribute to triggering, escalating, and sustaining conflict (UN Framework Team 2012), but it is rarely the sole cause (Matthew et al. 2009). Sopian (2014) argues that land conflicts are linked to structural problems, economic inequality, political marginalization, and competition over cultural values.

In particular, conflicting claims and conflicts often stem from unclear, overlapping maps and boundaries. Poor delineation of forest areas, compounded by a lack of spatial planning, has resulted in the conflicting spatial maps used by different agencies (GoI 2017b). One map may indicate that a parcel of land is set aside for one use, but a different map may designate that same land for a different use. Thus, differing maps may recognize various claims or licenses over a single area. 


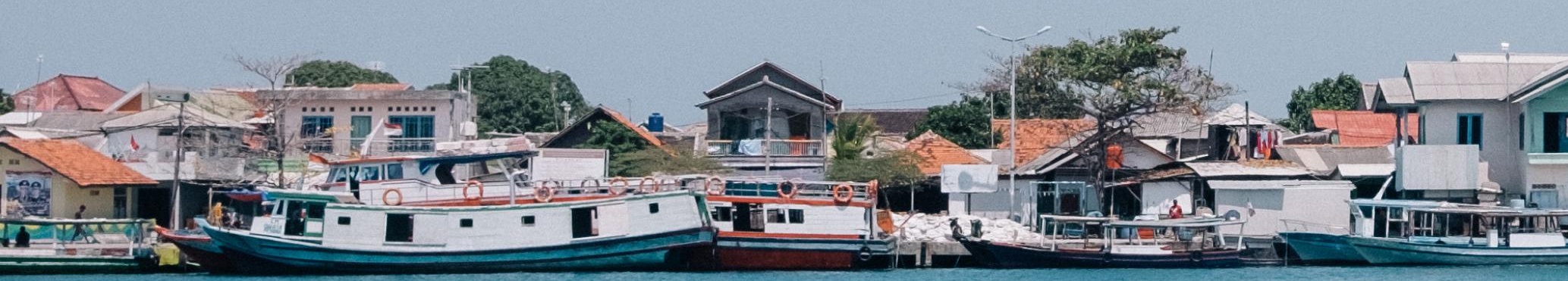

In the forest sector, the 1967 Basic Forestry Law gave the Department of Forestry (currently the KLHK) authority over 140 million ha of forest, covering around 70 percent of Indonesia's land (Campbell 2002; Contreras-Hermosilla and Fay 2005; Fay and Sirait 2002; Michon 2005; Safitri et al. 2015). However, these forest areas were only designated on paper. Many studies found that the government declared large swaths of land to be state forest areas; however, it did not adequately demarcate the boundaries, and people were already living in these areas under customary arrangements (Affandi 2017; Afiff and Lowe 2007; Rachman 2011; Srinivas et al. 2014). Fay and Sirait (2002) explain that no proper delineation process was conducted, and existing land claims were not settled. This situation left forest areas conflicted by overlapping claims, differing designations, claims of customary rights, and both forest and nonforest uses. According to Tjondronegoro (2006), poorly delineated adat land and forest areas have exacerbated exclusion and the risk of conflict. Fay and Sirait (2002) further argue that though the 1999 Forestry Law was an improvement from the 1967 law, people living in the forest areas still opposed some of the designated areas. Designated forest areas are strictly used for forestry activities, and these activities required licenses.
Similarly, in the plantation sector, IRIN News (2010) reports that the oil palm boom has unleashed a torrent of overlapping claims - with oil palm permits encroaching on communities' land rights. Without a proper resolution, these overlaps can develop into conflicts. The legacy of the government's long-term transmigration program has also sparked conflicts between indigenous people and migrants (IPAC 2013). Transmigration sites claimed as state land by the government were already occupied and claimed by indigenous people (Bachriadi and Wiradi 2014).

According to Moeliono (2011), this situation is especially problematic because the local government has the power over local spatial planning and seeks land for development but has little power in the forest area. A local government may designate a parcel of land for a different use than what is set aside by the national ministry. The discrepancies between maps and designations of forest and nonforest areas can lead to local governments issuing mining and plantation licenses in forest areas that are considered to be off-limits by the national government. Thus, these conflicting claims and policies on paper among government agencies can lead to land conflicts on the ground. 


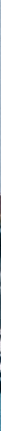

\section{A Problem Almost No Stakeholder, Sector, or Region Can Escape}

Understanding the nature of the parties involved could help clarify and address the regulations, asymmetries of power, and tendencies towards violence.

\section{Stakeholders}

The KLHK catalogs many types of land conflicts: between society and government, between communities and corporations, between communities and permit holders, and between government branches (GoI 2015). The KPA lists conflicts between citizens and private corporations (constituting 60 percent of all reported cases), between citizens and stateowned enterprises, between citizens and law enforcers, between citizens and the government and other groups, and among citizens (KPA 2019).

\section{Sectors}

Figure 3 lists the economic sectors affected by land conflicts. The KPA reports that these conflicts occur in forests, on plantations, along coastal or maritime areas, in mining areas, around infrastructure sites, on property, around military facilities, and on farmland (KPA 2020). However, forests and plantations are where the overwhelming majority take place. Figure 3 shows the relative portion of each sector measured in the number of cases and the land area under conflict. The forest and plantation sectors account for approximately 30 percent and 26 percent, respectively, of Indonesia's total land under conflict.

Similar figures are also found in the Komnas HAM (GoI 2017a) annual report. It states that plantations, forestry, mining, and infrastructure are the main sectors contributing to land 


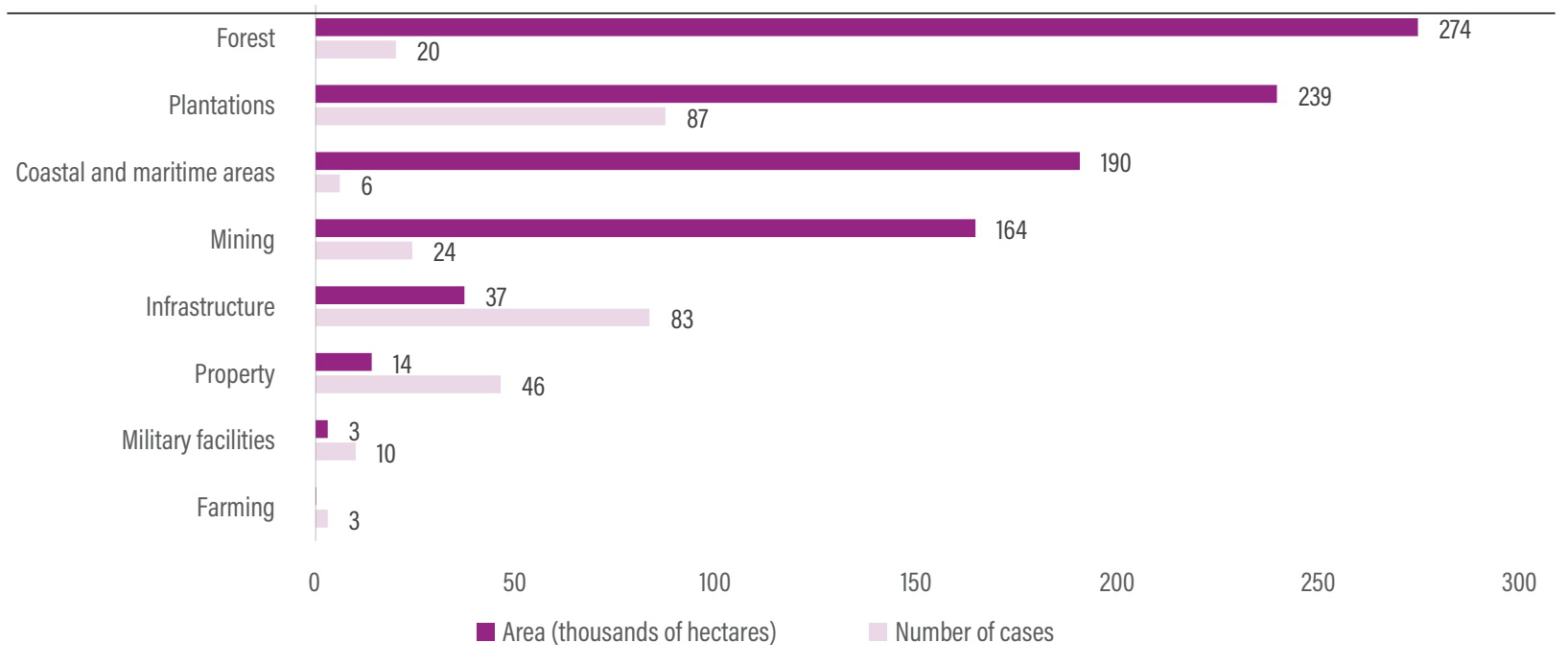

Source: KPA 2020.

conflicts. The second-largest contributor is the forestry sector, where, according to the same report, conflicts arise from the KLHK unilaterally claiming areas to be forest or conservation areas. However, the sector that accounts for the most conflicts by far is palm oil production. This fast-growing industry makes up a rising share of Indonesia's GDP and exports. Plantations have spread and multiplied, especially across Sumatra, Kalimantan, and Sulawesi.

Region

The Indonesian provinces experiencing the most land conflicts are Sumatra, Java, and Kalimantan. The KPA (2019) reports that, in 2018, 43.5 percent of cases were in Sumatra, 34 percent in Java, and 12 percent in Kalimantan. The KLHK (GoI 2015) also ranked Sumatra first and reported a significant number of land conflicts between communities and corporations and corporations and the government. It found that Kalimantan had the second-highest number of cases, and a significant share occurred between corporations and the government. According to Wulan et al. (2004), the number of land conflict cases related to the forestry industry spiked during decentralization in Indonesia and was concentrated in Kalimantan, Sumatra, and Java.

\section{The Financial and Human Costs of Land Conflicts}

The financial cost of these conflicts is astronomical. Currently, land conflicts cause a 29-fold increase in the operational costs of land-based projects (Munden Project 2012). In Indonesia, land conflicts can raise the annual operational and investment cost per hectare by 88 percent and 177 percent, respectively, resulting in indirect costs of US\$9 million (Barreiro et al. 2016). For large-scale mining corporations, tenurial issues can cost $\$ 20$ million per week because of delayed production (Davis and Franks 2014). Seventy-three percent of delayed oil projects are caused by risks associated with resistance from stakeholders and local communities (Hackenbruch and Pluess 2011). However, these costs do not just burden corporations. Following land conflicts, 35 percent of the commodities that were previously free to local communities must now be purchased (Zakaria et al. 2019). Land conflicts can restrict the water supply, forcing households to pay Rp 1.3 million per family per month (Zakaria et al. 2019). They also can force households to work an additional 35 hours per month to make up for lost income (Zakaria et al. 2019). Taking the steps needed to address the root causes of conflicts over land would save money and lives and lift the heavy burden that recurring tensions and clashes over land impose on Indonesians and their government. 


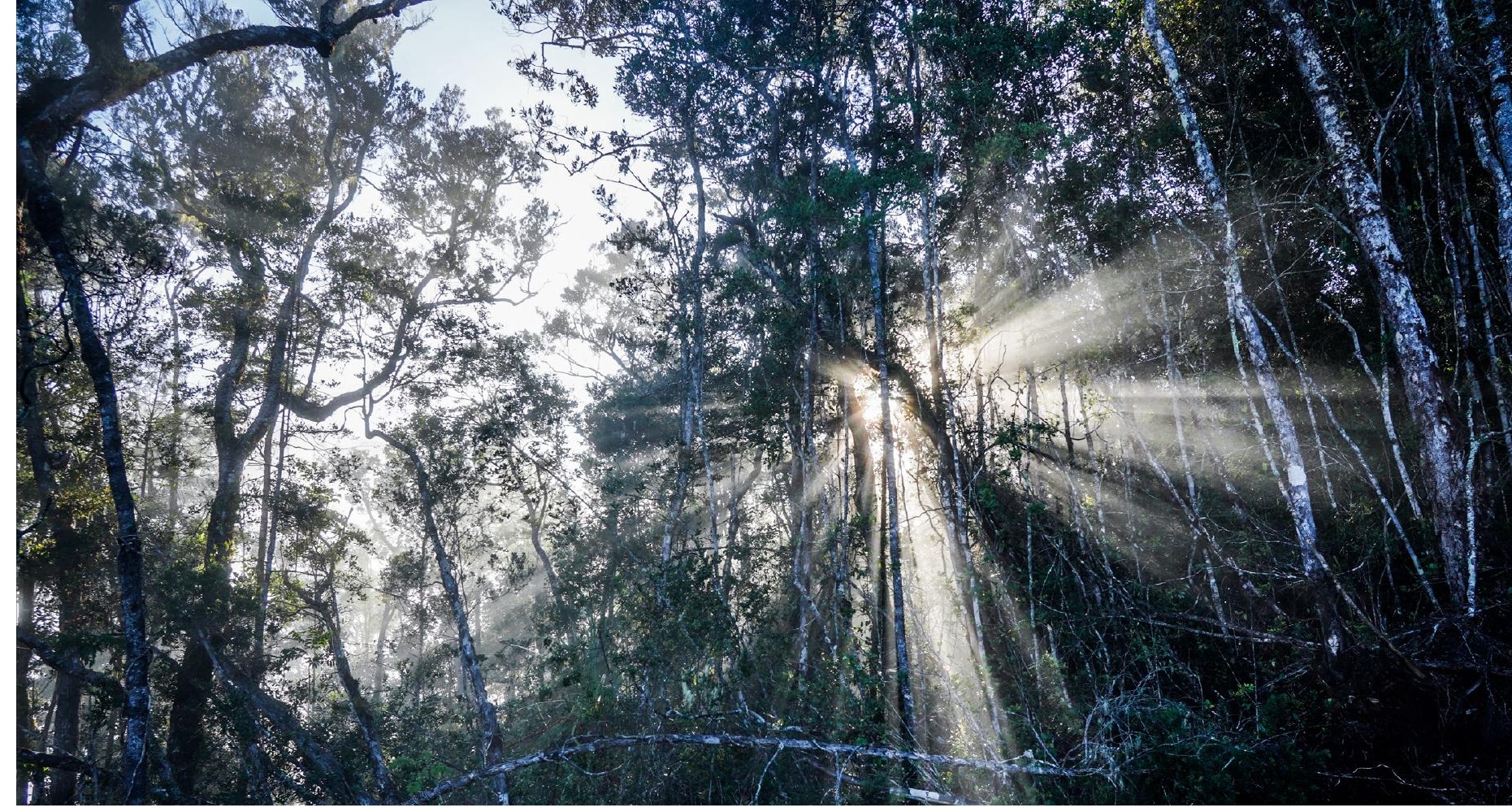

The human costs of land conflicts are also significant. The KPA (2015, 2016, 2017, 2018, 2019, 2020, 2021) further reports that, between 2014 and 2020, 1,693 people were arrested without due process (criminalization), 1,275 were victims of harassment, 92 were shot, and 85 were killed (Figure 4). The KPA blames most of this violence on the police, who were behind 21 of these cases. Seventeen cases were perpetrated by people listed as thugs, followed by 11 cases by the army, and 7 by the municipal police. The KPA observes that civilians often view police officers as causing consternation and fear, and they believe they serve as a powerful tool for corporations and the government rather than as neutral mediators of the law. Furthermore, according to Siscawati (2017), conflicts over natural resources often involve gender-based violence, where women and girls are often victims. Poverty caused by agrarian conflicts results in low educational attainment for girls, maintains underage marriage traditions, and increases human trafficking of women and girls.

Figure 4 | The Total Number of Victims of Criminalization, Harassment, Shootings, and Killings due to Land Conflicts, 2014-2020
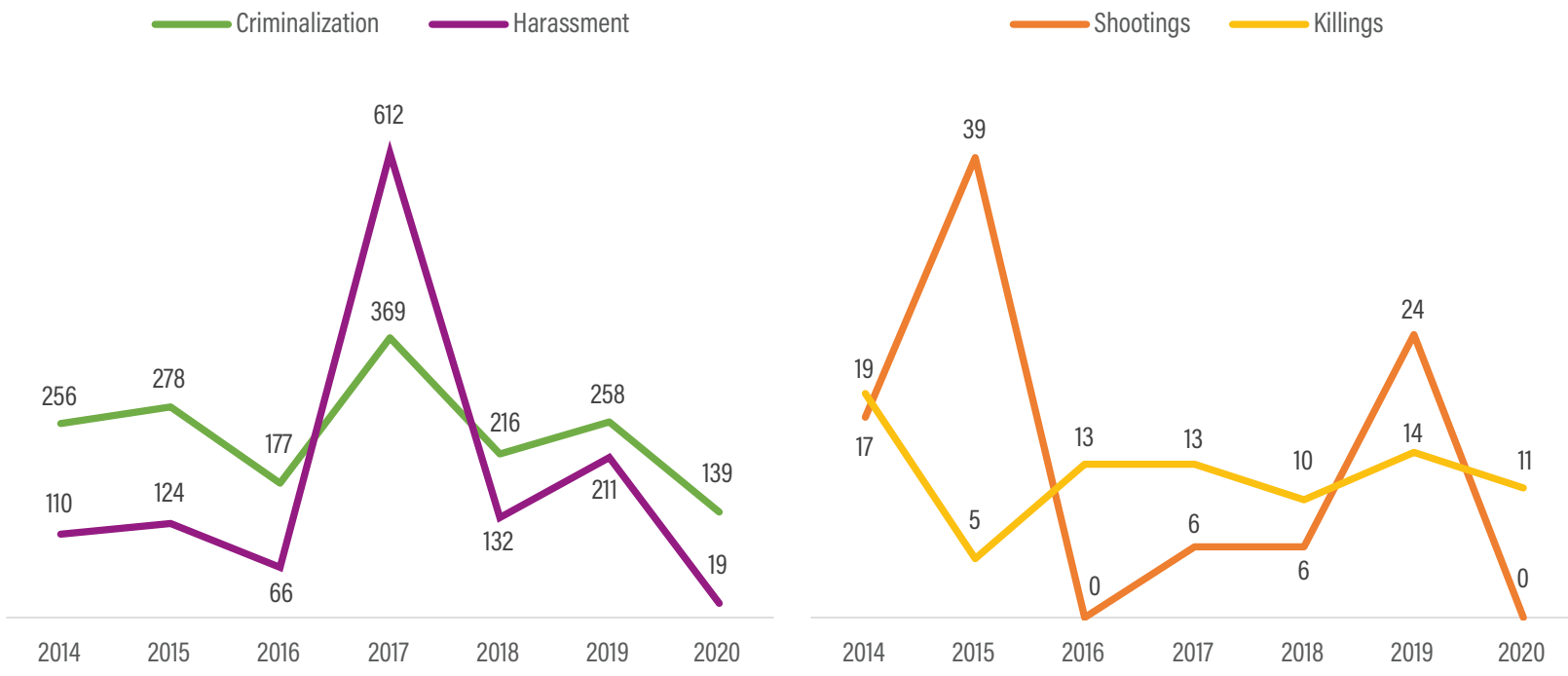

Source: KPA 2015, 2016, 2017, 2018, 2019, 2020, 2021. 
r. 9 ,

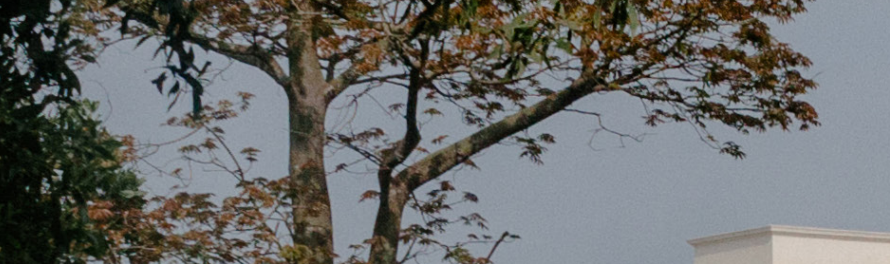

2xd.

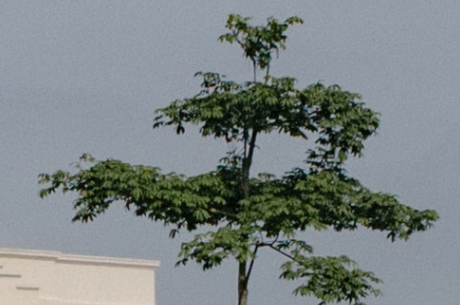

(1)

3.

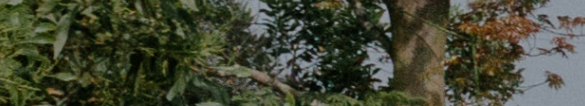

1.

4

)

stith

1.5.

( 3 is

(2) $12 \times$

3)

(n)

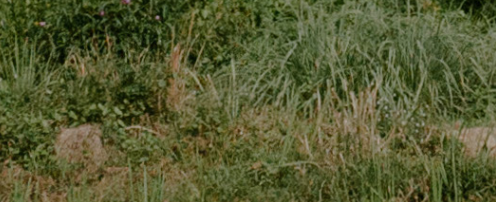

1.

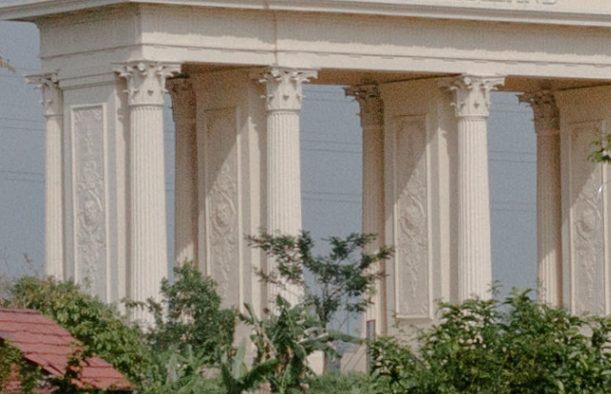

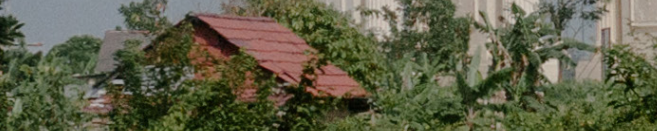

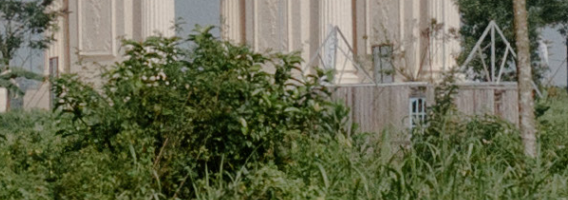

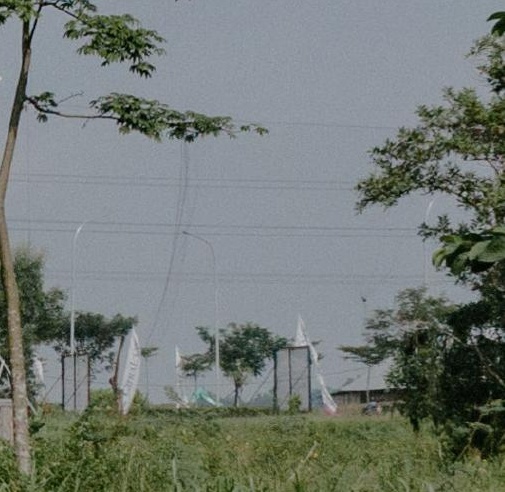

)

3.1. 28

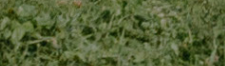

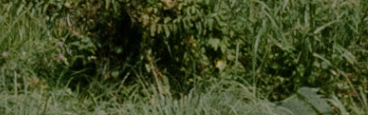

1.

Nisting

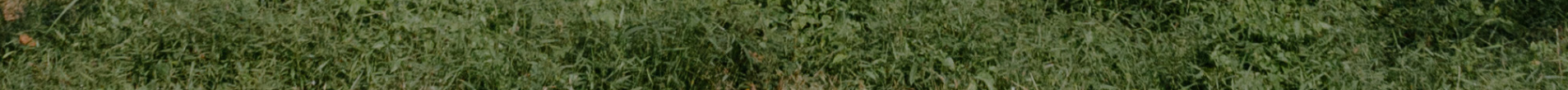

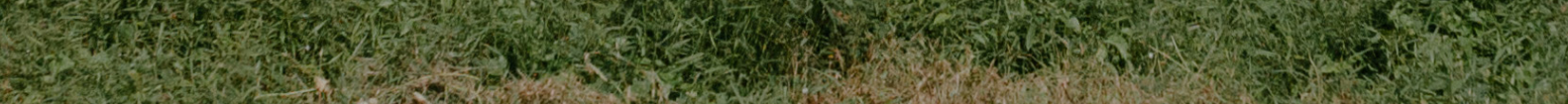

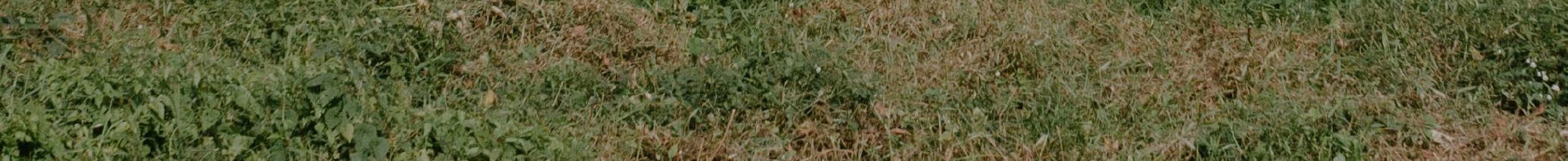

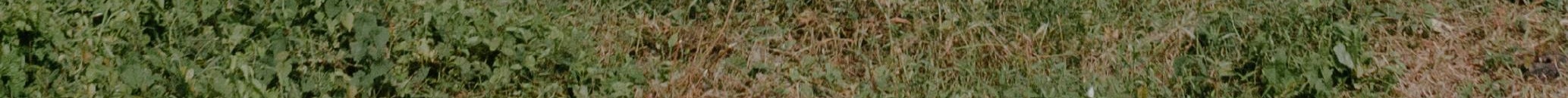

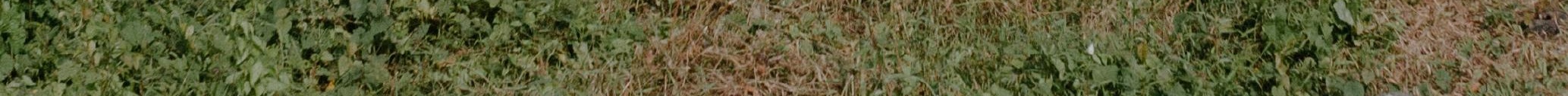

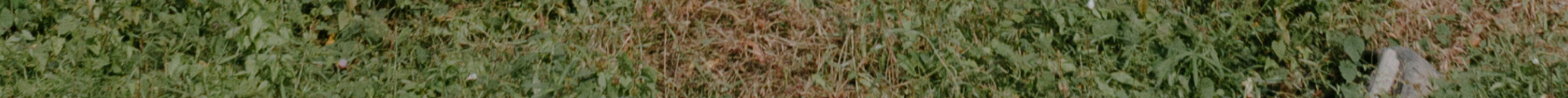

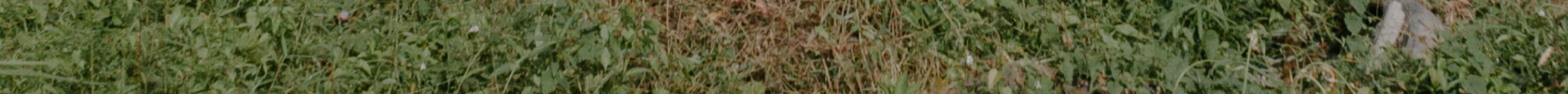

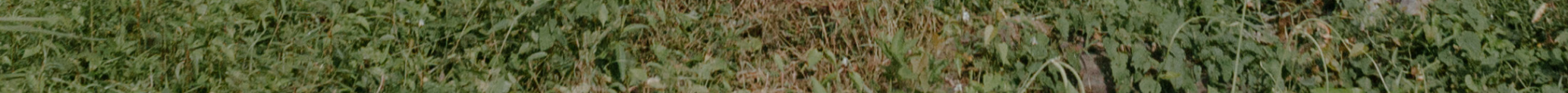

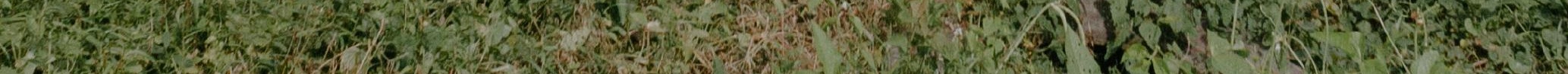
1.5.

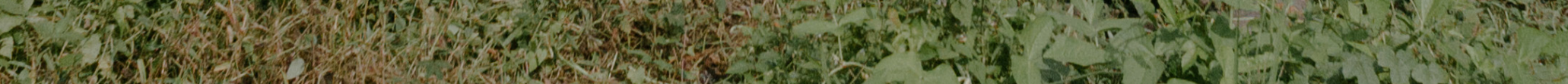

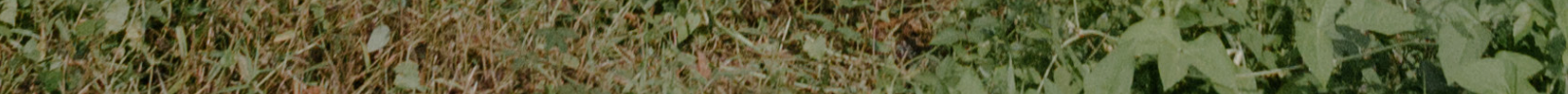

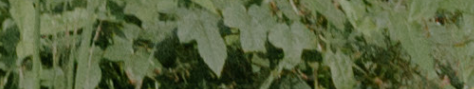




\section{INSTITUTIONAL BARRIERS HAMPERING LAND CONFLICT RESOLUTION}

This section discusses our findings, which comprise three levels of institutional barriers: the strategies and institutional framework, the operational framework, and land governance and political will. These barriers significantly impact the operational effectiveness of national government institutions and their attempts to resolve land conflicts. 
This section discusses our findings, which comprise three levels of institutional barriers that significantly impact the operational effectiveness of national government institutions and their attempts to resolve land conflicts (Table 3).

\section{Strategies and Institutional Framework}

\section{The Lack of Strategic Coherence at the Implementation Level}

\section{Administrative approaches to land conflict resolution}

There is a fundamental issue on the approach under the current formal institution. Whereas President Joko Widodo's programs aim to take on structural problems that tilt the playing field in favor of the wealthy and well connected, the institutions tasked with land conflict resolution still heavily rely on the administrative approach. The BPN, the lead referee in land conflicts, as reflected in its minister's Regulation No. 11 of 2016 on Land Related Cases Resolution, perceives land conflict primarily as an administrative problem requiring an administrative fix only, such as revoking or revising land titles. This narrow view of the problem deflects attention from a host of factors and forces that drive conflict and need to be addressed.
As Li (2007) notes, administrative solutions gloss over structural problems, such as entrenched inequality and asymmetries in power and influence. In the administrative approach, a license holder may have the right to cultivate the land against community claims. Further, the license holder may have a letter signed by community representatives releasing community rights. Although the license may seem administratively right and legitimate, it may maintain structural conflicts where the community experienced the injustice of not having enough power to reject the license. The Alliance of Indigenous Peoples of the Archipelago (Aliansi Masyarakat Adat Nusantara) says the administrative approach often fails to recognize or defend the adat land rights (Nugraha 2019). Land conflict involves a complex matrix of crosscutting issues. Multiple factors and actors aiming for expedited superficial solutions could potentially lead to the reemergence of conflict rather than its resolution.

\section{Too little, too late}

Besides this lack of explicit coherence, the administrative approach also tends to be reactive and ad hoc instead of preventive, mitigating, and systemic. Instead of stopping conflicts or preventing them from escalating, Reinjani (2018) finds that these interventions occur when

\section{Table 3 | Summary of Institutional Barriers Hampering Land Conflict Resolution in Indonesia}

\begin{tabular}{l|l}
\hline LEVEL & INSTITUTIONAL BARRIER \\
\hline $\begin{array}{l}\text { Strategies and } \\
\text { institutional } \\
\text { framework }\end{array}$ & - Utilization of administrative, reactive, and ad hoc approaches to land conflict resolution \\
\hline $\begin{array}{l}\text { Operational } \\
\text { framework }\end{array}$ & - A complex and scattered set of institutions are unable to coordinate to resolve conflicts effectively \\
& $\begin{array}{l}\text { supports cross-institutional coordination } \\
\text { - Land and land conflict data and information systems that are inaccurate, not unified, and unofficial } \\
\text { - Lack of skilled and trained workers to comprehensively resolve land conflicts and lack of funding }\end{array}$ \\
\hline $\begin{array}{l}\text { Land governance and } \\
\text { political will }\end{array}$ & $\begin{array}{l}\text { - Rampant corruption, conflict of interest, and weak law enforcement can trigger and worsen land } \\
\text { conflicts and hamper their resolution. } \\
\text { - Lack of strong political will and support from the nation's top leaders to push for institutional reform }\end{array}$
\end{tabular}

Source: WRI authors. 
conflict erupts into violence that creates real and substantial damage. For the most part, anticipating or managing conflict is seldom a concern when licenses are granted. Government records and documents illustrate how heading off conflict has not been a priority. In 2015, under the nuanced social forestry agenda, the KLHK established a new Directorate General of Social Forestry and Environment Partnership (Direktorat Jenderal Perhutanan Sosial dan Kemitraan Lingkungan; Ditjen PSKL), which focuses on work in the Social Forestry Program. Under Ditjen PSKL, a directorate is specifically tasked with handling tenurial conflict in forest areas and customary forests (Direktorat Pengaduan Konflik, Tenurial dan Hutan Adat; PKTHA), but progress has not been satisfactory. Discussions with multiple resource persons indicate that exercising this function has not been a priority for the KLHK.

Government agencies mandated to deal with land conflicts mainly record conflicts reported by the disputants. As part of the One Map Initiative, it is only recently that the government has begun trying to detect overlapping land claims that could lead to open conflict. However, this more proactive approach has not yet included all land rights or licenses; for example, it excludes plantation (including oil palm) licenses and potential claims by communities often off the official maps. Mitigating the costs of overlapping land permits, mostly born by local communities (Johnson 2015), would require a change in longentrenched habits and perspectives. However, in the long run, a reactive approach is less costeffective than a preventive approach (Brown and Keating 2015).

\section{Too permissive}

The overall reactive, administrative, and case-bycase approach creates opportunities for private companies to grab land, setting off conflicts with communities that were there first. This situation can be seen in the conflicts involving the oil palm business. As demand for the oil accelerated, land grabbing in Indonesia's plantation industry caused more conflicts, such as when 632 communities clashed with oil palm operators in 2016 because the communities had not been consulted before the industry's expansion (IRIN News 2010). Even in a context where the private sector is willing to change its practices, Johnson (2015) observes that the government appears neither enthusiastic about nor committed to






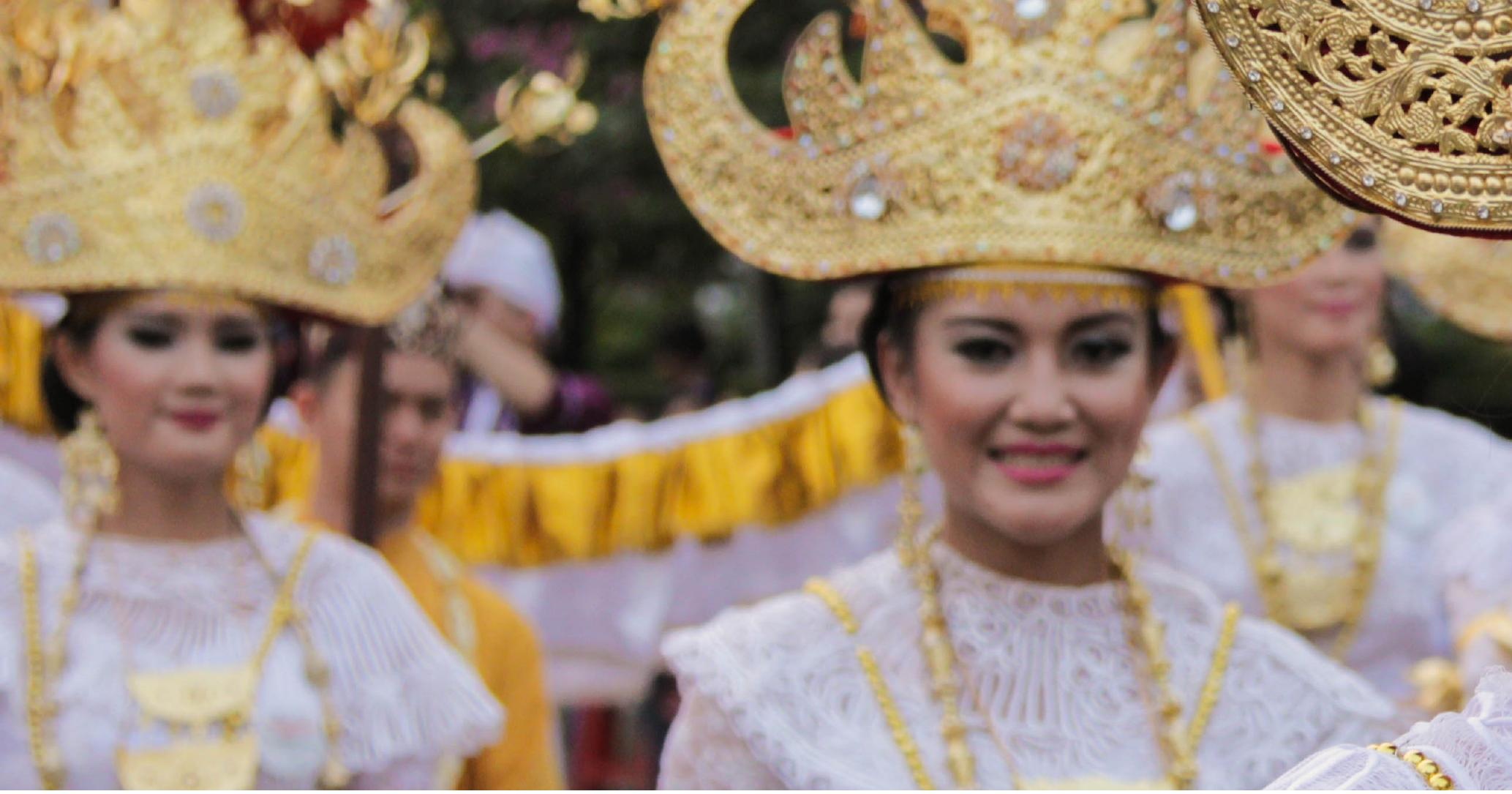

cracking down on the roots of land conflicts. This attitude has created space for other risks to grow, including the involvement of more opaque firms that have less incentive to follow necessary regulations or adhere to standards. $\mathrm{Li}(2007,267)$ argues that initiatives to prevent and mitigate conflict that only focus on dealing with local communities and warring parties on the ground will be futile unless they also address the underlying factors that enable overlapping permits and land grabbing.

\section{Complex and Scattered Institutional Arrangements}

For the president's initiative and various institutions to work effectively, they need to overcome barriers to coordination between disparate government policies and institutions. Synchronizing land-use maps would have represented a significant step towards seriously addressing land conflict. However, it has yet to work well because it is not well integrated with other president-led policies, including the Social Forestry and Agrarian Reform Programs. The BPN, which is charged with resolving land conflicts, has not aligned its policies and practices with the principles enshrined in the Agrarian Reform and Social Forestry Programs. Indeed, it often appears to work at crosspurposes with them.

\section{The breakdown}

This situation is caused by a complex and scattered institutional arrangement. Land conflicts are divided by sectors. The KLHK and the BPN handle complaints and claims regarding land rights or uses in forest areas and nonforest areas, respectively. The KLHK is also in charge of conflicts related to environmental services such as access to clean water and air. In plantation areas, the Ministry of Agriculture (Kementerian Pertanian; Kementan) has the authority to facilitate conflict resolution.

Further, conflicts are delineated based on severity. The Coordinating Ministry for Political, Legal, and Security Affairs (Kementerian Koordinator Bidang Politik, Hukum, dan Keamanan; Kemenko Polhukam) and the Ministry of Home Affairs (Kementerian Dalam Negeri; Kemendagri) can manage land conflict once the conflict evolves into a social conflict where physical clashes between groups of people during certain periods affect national instability and disintegration. In cases of open conflict involving violence and security risks, the National Armed Forces (Tentara Nasional Indonesia) and the National Police (Kepolisian Negara Republik Indonesia) have the authority to secure the situation. When conflicts could lead to social disintegration that might affect national stability and hamper development, Kemendagri and the Ministry of Defense (Kementerian Pertahanan; Kemenhan) can become involved. 
The lack of clarity inherent in this complex institutional constellation causes confusion among disputants. They may not know which authority is competent and responsible for resolving a conflict or where any incident should be reported. This situation can exacerbate tensions and further reduce trust towards the system (Gumilang 2016). Having a transparent and credible channel for conflict resolution could minimize grievances and the risk of conflicts (Gumilang 2016).

\section{Efforts to encourage institutions to work together}

The Indonesian government has tried to address this. The Management of Social Conflict Act No. 7 of 2012 attempts to bridge the divides between government bodies. Its ostensible aim is to foster more integrated conflict resolution by developing cross-sectoral institutions for social conflict resolution. Although this law is not specifically about land conflicts, it recognizes natural resources as one of the sources of social conflicts. However, it can only be applied very narrowly. It is restricted specifically to cases of ongoing and violent social conflict defined as a feud or physical clash between two or more groups with widespread impacts that may result in reduced security and lead to social disintegration on a scale that could threaten national stability and hamper development. These exacting criteria mean that its regulations exclude all conflicts that do not meet these thresholds, and so this legislation offers only relatively limited benefits for resolving land conflict.

Government bodies created more recently to implement land reforms and address conflict seek to harmonize efforts as well. The One Map Policy tasked the Coordinating Ministry for Economic Affairs (Kementerian Koordinator Bidang Perekonomian; Kemenko Perekonomian) with aligning the work of relevant ministries and government agencies. Presidential Regulation No. 88 of 2017 on the Land Tenure Settlement in the Forest Areas established an ad hoc institution chaired by Kemenko Perekonomian to coordinate work across sectors. Presidential Regulation No. 86 of 2018 on Agrarian Reform established another ad hoc institution authorizing Kemenko Perekonomian to coordinate relevant institutions at the national and local level. Additionally, Presidential Instruction No. 2 of 2018 regarding the PTSL initiative also involved numerous related ministries and government agencies at the national and local government levels. Furthermore, the President's Executive Office (Kantor Staf Presiden; KSP) established the Team for Accelerating Agrarian Conflict Resolution in 2017.

Although they seek to bolster coordination, these ad hoc institutions established by the presidential regulations and policies face an uphill battle. This is true of the One Map Policy, the Land Tenure Settlement in the Forest Areas Program (Penyelesaian Penguasaan Tanah dalam Kawasan Hutan; PPTKH), the PTSL initiative, and the Team for Accelerating Agrarian Conflict Resolution. Our research found that the implementation of these laws and regulations still tends to take place in silos and lacks effective coordination. For example, by the end of 2019, the One Map Policy was still far from delivering one synchronized map. This is probably due to the persistent deadlocks in Indonesia's forestry policy cycle, which are caused by officials making empty or severely limited decisions (Sahide et al. 2018). The KSP appears to be the most powerful coordinator among the various institutions. However, a vast number of priorities within the president's agenda compete for the office's resources, including land conflict resolution. Although well-intentioned, the establishment of these ad hoc institutions adds more bodies to the already complex and crowded institutional patchwork of Indonesian land governance (Table 4). President Joko Widodo's initiatives aimed to integrate strategies at all levels to promote collaboration, not in shaping policy but in implementing it on the ground. But coordination has proved elusive, partly because new ad hoc institutions run up against institutions wedded to the status quo, accustomed to working in silos and seeing problems through their own tunnel vision (Table 4). 


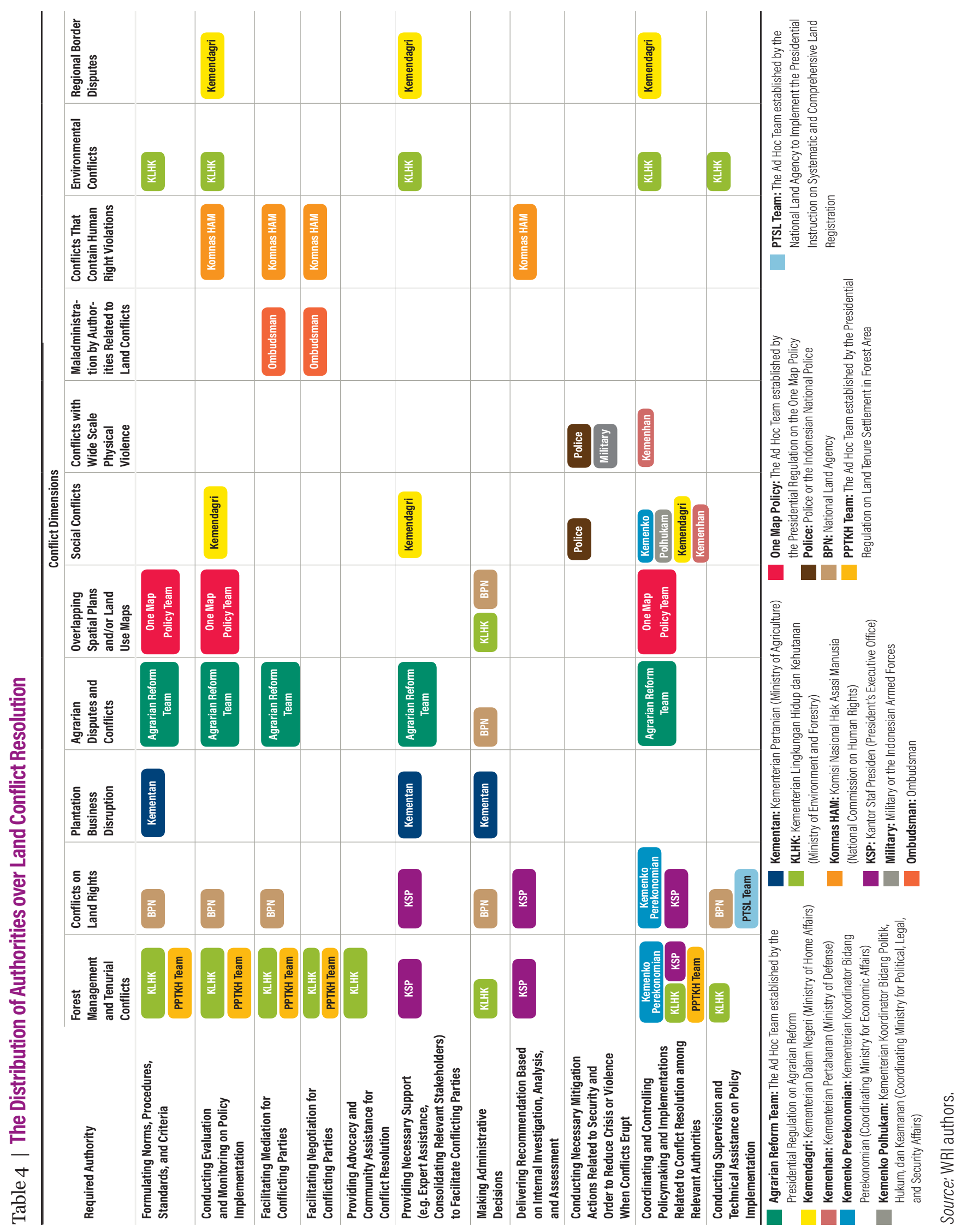




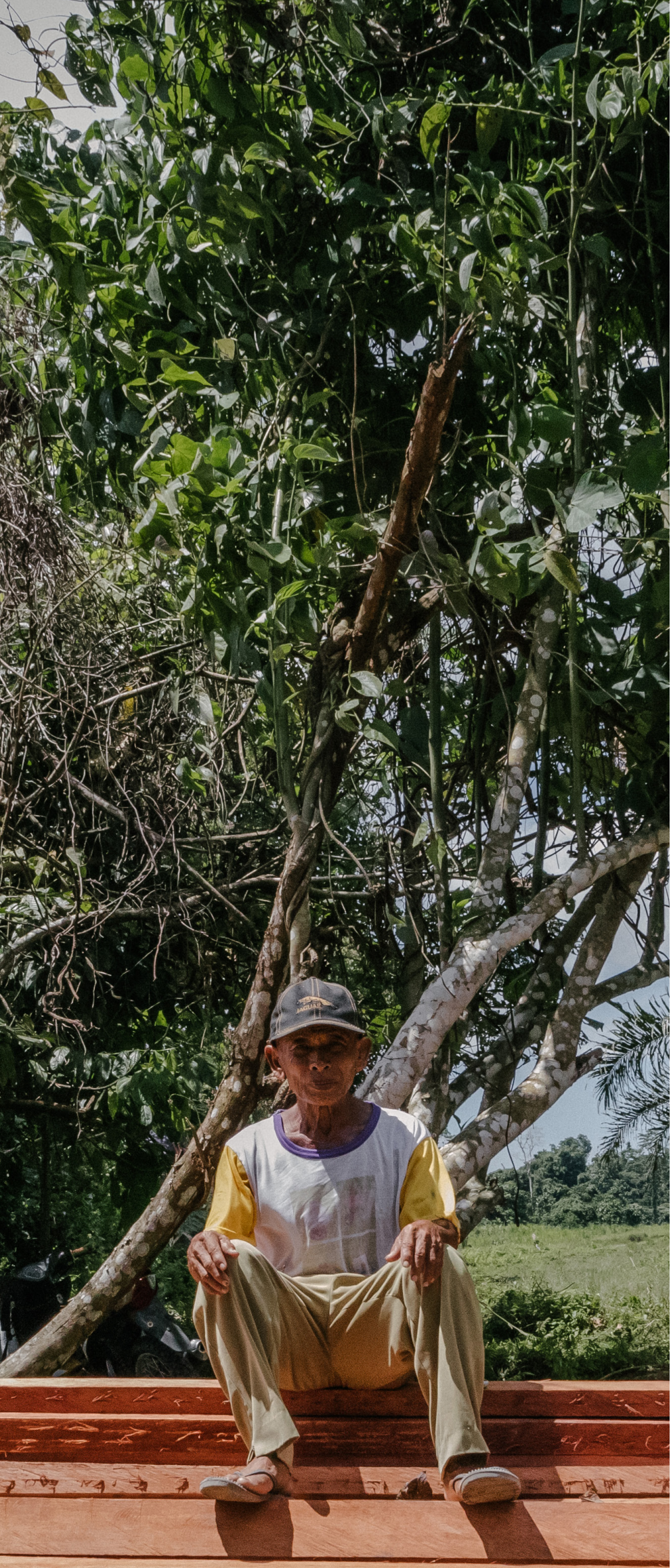

\section{Operational Framework}

A lack of operational guidelines

An absence of operational guidelines for comprehensive resolution

Existing guidance is largely restricted to administrative considerations. It provides little or no guidance on resolving disputes in ways that prioritize fairness, respond to demands for social justice, or confront underlying structural problems such as inequality. The necessary guidelines are absent in regulations, job duties, and just day-to-day procedures. We find that the lack of guidelines makes it difficult for frontline government workers to resolve conflicts because it is unclear which steps or decisions would be considered "correct" to bring about fair resolutions that address social justice and structural problems.

Interviews point specifically to a lack of guidelines to operationalize values of social justice within the conflict resolution process. This includes guidance on how to address disagreements over indigenous rights. Many resource persons say weak and vulnerable stakeholders find it difficult or impossible to access national-level government institutions that often hold the keys to resolving conflicts. Some say that asymmetrical power between various stakeholders leaves local communities at a severe disadvantage. In disputes over land, they often face the steepest hurdles in collecting the necessary documentation to claim their land rights.

An absence of operational guidelines for crossinstitutional coordination.

No procedures have been laid out to direct agencies on how to coordinate with one another. The ad hoc institutions that are supposed to foster coordination, such as the One Map Policy, the PPTKH, and the Agrarian Reform Program, were not equipped with an operational mechanism demarcating how each ministry or agency ought to exercise its authority or collaborate to resolve conflicts. The Social Conflict Law No. 7 of 2012, which attempted to foster cross-sectoral collaboration to resolve conflicts (after the cessation of violence), similarly remains bereft of operational 
guidelines. Resource persons consulted for this study frequently cited the need for more holistic operational guidelines that could cover issues from the site level to the national decisionmaking level.

Even one of the most promising efforts to build a more coherent and collaborative mechanism for conflict resolution in the forest areas is not yet operational. This is a joint regulation issued in 2014 by the Ministry of Forestry (currently the KLHK), Kementan, the Ministry of Public Works, and the BPN (the functions of the latter two are currently discharged by the Ministry of Agrarian and Spatial Planning). This regulation provides a unified business procedure for the four ministries to use, but it still lacks any technical guidelines for its operation. Muhajir (2015) reports that the BPN unilaterally issued its own technical guidelines, but the KLHK dismissed them and demanded a set of joint technical guidelines that have not been developed. The joint regulation is currently in limbo; it has been neither revoked nor implemented (Box 1).

\section{BOX 1 | OPERATIONAL PROBLEMS WITH THE 2014 JOINT REGULATION}

The 2014 joint regulation stipulates that the business process relies heavily on decisions made by ad hoc teams assigned to inventory tenure, ownership, and utilization of forest land. The formation of such teams also relies on the willingness of the local government to cooperate and the ability of relevant communities to forward a claim. There are no operational mechanisms that address either a local government's lack of political will to seek resolution or a local community's lack of capacity to forward a sufficient claim. Further, guidance on how ad hoc teams should analyze and form their recommendations is scant. The teams are instructed only to analyze juridical and physical data in spatial and textual forms and to use these to draw one of these three possible recommendations: to enforce and recognize rights over the land, to proceed under the Agrarian Reform Program, or to delineate the land as a community forest. The lack of guidelines outlining how these recommendations should be considered, as well as the limited number of possible recommendations, reveals an inflexible approach towards conflict resolution, which may well not apply to the particularities of conflicts.

Source: Muhajir 2015.
This absence of clear and coherent operational guidelines can leave officials and institutions overwhelmed when a conflict breaks out, and even less likely to be able to resolve it.

\section{Poor land information and conflict data systems}

The 2011 One Map Policy showed the government's seriousness about solving these problems. It marked Indonesia's first effort to consolidate national land usage maps using a common geo-referencing system (Srinivas et al. 2015). Until that point, Indonesia lacked a complete geo-referenced inventory of land parcels in either forest or nonforest areas. Several nongovernmental organizations, such as the KPA, have collected and regularly published data on land conflicts. Still, Indonesia remains without a unified, complete system for collecting data on land conflicts.

\section{Poor Land Information and Conflict Data Systems}

Although authorities do collect data on land conflicts, the data is not comprehensive, and the definition of land conflicts is not standardized. The BPN does not distinguish between small land disputes between two home plots and violent conflicts involving entire communities. Levels of detail and accuracy vary, and agencies do not proactively try to identify and locate where land conflicts exist or where there is a risk/ potential of land conflicts. Also, many reports are submitted to multiple authorities (such as the BPN, the KLHK, Komnas HAM, the KSP, etc.), and there is no synchronization between the agencies. As a result, reports are either double or triple counted, or they bounce back and forth between agencies, which deny they have jurisdiction, do not record them in databases, and tell claimants to report to the other agencies. Agencies often disregard nonadministrative data such as historical injustices or cultural violations; thus, the data is incomplete.

\section{Land data is not unified}

The difficulty of verifying and merging information presents an obstacle to creating a unified data set. Different agencies each hold various pieces of the puzzle that the government needs to put together to get a full picture of the land it oversees. But these agencies use different maps and refuse to acknowledge the maps of 
other agencies. As an example, the BPN and the KLHK still use different map resolutions (different levels of accuracy and granularity), which can obscure borders between forest and nonforest areas. The World Bank (2018a) finds that Indonesia's lack of an integrated land database complicates the management of land and natural resources by generating conflicting decisions. Indeed, the absence of publicly available unified data directly contributes to the emergence and escalation of land conflicts, especially those involving private companies and local communities (Yuliawati 2017). The absence of comprehensive, accurate data creates fundamental challenges to efficiently managing conflicts (GoI 2017b). This means that the very nature and pattern of Indonesia's land conflicts remain poorly understood, even by policymakers.

\section{Data is not transparent}

Lastly, the data is not accessible to the public. CSOs and experts are not demanding complete transparency, but they want some of the data to be open for the public to access, such as a summary of cases, where they are located, their types, and how they were adjudicated. The lack of transparent official data creates ambiguity, ignites conflicts, fuels distrust between the government and CSOs, and makes disagreements between various stakeholders difficult to resolve. For example, when the government and CSOs disagree over land conflict data, each has sought to refute the other's findings, and this has hampered effective collaboration. Figure 5 shows the sharp divergence between data on land conflicts from different government sources and the KPA.

\section{A Lack of Institutional Capacity to Deal with Land Conflicts \\ Lack of necessary tools}

Limited institutional capacity is recognized as a ubiquitous problem. Many agencies that oversee land conflicts lack the necessary tools to conduct proper conflict assessments or aid in conflict resolution. Based on conversations with our resource persons, we found that one government office receives more than 5,00o complaints per year, which far exceeds the capabilities of its personnel and funding. These officials are required to follow their institution's technical guidelines, which are, once again, limited in their scope and oriented towards fulfilling administrative duties or reacting to problems on the ground.

\section{A lack of skilled workers}

The government lacks full-time qualified mediators, relying instead on outsourcing this role to experts on a case-by-case basis. The PKTHA's Independent Team of Tenurial Conflict-Handling in Forest Areas, for example, consists of an academician, a certified mediator,

Figure 5 | The Number of Cases of Land Conflicts or Disputes by the BPN, Komnas HAM, the KLHK, and the KPA, 2009-2019

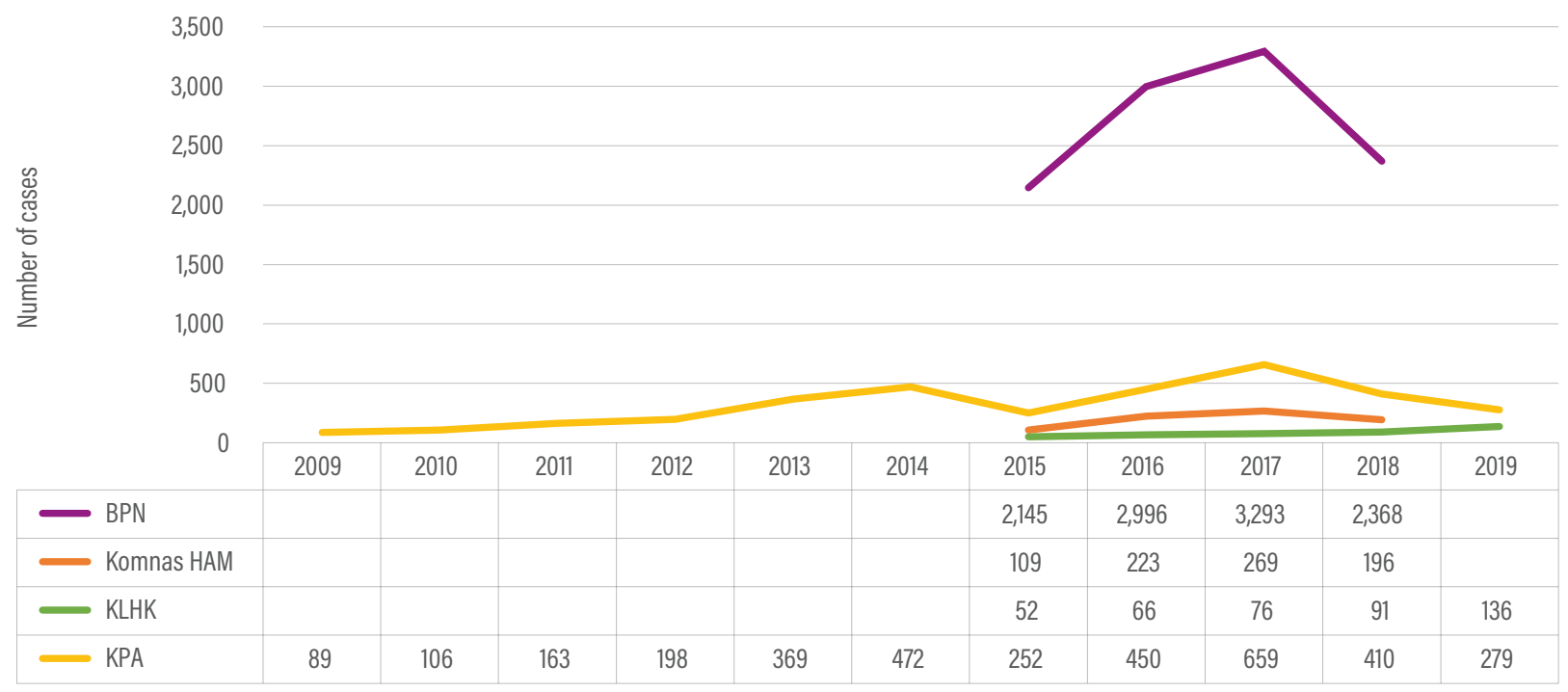

Notes: BPN = Badan Pertanahan Nasional (National Land Agency); KLHK = Kementerian Lingkungan Hidup dan Kehutanan (Ministry of Environment and Forestry); Komnas HAM = Komisi Nasional Hak Asasi Manusia (National Commission on Human Rights); KPA = Konsorsium Pembaruan Agraria. Sources: Gol 2019a, 2019b, 2020b; KPA 2010, 2011, 2012, 2013, 2014, 2015, 2016, 2017, 2018, 2019, 2020; Nugraha 2019. 
and a government worker who are called upon only when the need arises. The outer regions of Indonesia struggle even more in creating these teams and are often forced to rely on data from the Geospatial Information Agency rather than visiting sites and gathering information themselves. All of this is made worse by the system of rotating civil servants between government offices that thins the ranks of dedicated staff rich in hands-on experience.

\section{A culture of pessimism is prevalent}

Furthermore, government officials suggest that there is little or no incentive to innovate. The current performance review system and reporting mechanisms provide no incentive for officials to resolve conflicts, even within their institutional jurisdiction, especially if this would mean stretching the boundaries of their individual administrative responsibilities. In addition, officials responsible for addressing land conflicts often express pessimism at the prospect of doing this successfully. Although the sheer magnitude and complexity of these disputes can indeed be overwhelming, it is clear that the inadequate tools and resources they are given contribute to this sense of futility.

\section{A lack of funding}

The budget for conflict resolution is relatively small and is spread among institutions that have little or no incentive to pool resources. The state budgeting cycle is another hurdle. Our resource persons shared that resolving conflicts can take many years, whereas money is currently only budgeted on an annual basis, making it hard to plan and budget in advance for ongoing work. Existing resources, whether from the state budget or external sources, could be consolidated and stretched. But this rarely happens, and it appears that even a $\$ 200$ million loan from the World Bank (2018b) to accelerate agrarian reform has not yet delivered useful resources for conflict resolution. Although increasing budgets would assist conflict resolution, operational inefficiency wastes precious resources. For example, ad hoc teams are costly to form and lack proper resources and a coherent strategy to holistically handle conflicts. This prevents members from passing on knowledge or tackling thorny problems.

\section{Land Governance and Political Will}

\section{The Plague of Corruption \\ Corruption and land conflicts}

In Indonesia and elsewhere, corruption is often crippling efforts to govern land fairly and efficiently. Globally, 1 out of every 10 people reported paying bribes when dealing with common land issues (Riaño et al. 2009). Riaño et al. (2009) reveal that countries where land corruption is a major challenge have weaker economies, lower levels of development, and poorer crop yields. Pyman et al. (2014) also suggest that corruption hobbles governance and fuels conflicts, including conflicts over natural resources and land. It does this by weakening the tenure system, subverting sound land management, and undermining protections for community rights and access to land. Moreover, corruption often results in ineffective and unequal development, which further increases grievances and leads to more conflicts.

When land governance becomes mired in corruption, it can spawn conflicts on the ground (KPA 2015, 8). It can strip officials of the power to determine lawfully and justly who gets permits and how conflicts get resolved. Affected communities, realizing they have limited space and say in the system, can react violently. The government, in turn, often resorts to state violence to try to deal with land conflicts, which further marginalizes local communities and exacerbates grievances (Susan 2015). Thus, it is imperative to address corruption before it cripples effective conflict resolution and corrodes trust in the system.

\section{Corrupt land-use and management practices}

Findings by Moeliono (2011) show that many decisions regarding land use and management in Indonesia happen behind closed doors. Vote buying and money politics remain widespread (Gecko Project and Mongabay 2017a, 2018b, 2019b). Indonesia ranks 89 th out of 180 in the 2018 Corruption Index and receives a low score of 38 out of 100 (Transparency International 2019). Indonesia's relatively narrow legal definition of corruption creates gray areas and loopholes that can be exploited. For example, it is not technically illegal for government officials to issue permits to their family members through shell companies. Practices such as these mean that land governance in Indonesia is riven with 
cronyism and corrupt practices (Keefer 2002). The government is often swayed by economic and political elites, aided and abetted by scant accountability and endemic corruption, who benefit from the current system. Thus, in the last decade, a number of local government officials, including at least four governors, four mayors, and two heads of local agencies, have been convicted of corruption related to landuse licenses. Overlapping and unclear land planning and regulations open up loopholes or cracks that incentivize corrupt practices. Risalah (2020) reported that the Corruption Eradication Commission (Komisi Pemberantasan Korupsi; KPK) stated that unclear spatial plans lay out the red carpet for corruption, especially corruption in permit granting.

\section{Regulatory capture sidelines the public interest}

Regulatory capture is also a problem. This is the case when regulatory authorities issue regulations for the benefit of certain people instead of for the public interest (Greenpeace et al. 2019). Some actors wield money and connections to influence the way laws and regulations are drafted and implemented. They apply pressure through bribery, insider trading, and political influence. As a result, the regulatory process will tend to cater exclusively to certain groups that share similar interests. They draw public officials into a kind of tunnel vision where only their own interests and perspectives within the sector are visible or important. This can result in overlapping, excessive, and unjust regulations that enrich them at the expense of vulnerable groups (Muhajir et al. 2020; Box 2).

\section{Conflicts of Interest within Government Agencies}

Under current institutional arrangements, the very same authorities tasked with resolving land conflicts are the ones that may have helped cause them in the first place. They may have done this by shaping policies, denying or recognizing rights, allocating licenses, or even by removing communities from state-owned land. During an FGD, numerous participants wondered whether institutions that issue land rights or licenses should adjudicate disputes over them. They recounted how the BPN and the KLHK may dismiss challenges against their own decisions or designations. This means that when adat communities complain that their lands have been improperly incorporated into state forests,

\section{BOX 2 | OVERLAPPING AND UNCLEAR REGULATIONS ON ADAT COMMUNITIES' LAND RIGHTS}

Indonesia's 1945 Constitution recognizes the rights of adat communities, including land rights, but enforcing this requires regulations. Under the existing legal framework, there are separate procedures for recognizing adat communities and defending adat land rights. The recognition of adat communities is handled by local governments. However, national regulations have divided this authority. Ministry of Home Affairs Regulation No. 52 of 2014 requires a decree from a regent or mayor to recognize the adat communities in forest and nonforest areas, and Ministry of Environment and Forestry (Kementerian Lingkungan Hidup dan Kehutanan; KLHK) Regulation No. P.17 of 2020 requires a regional regulation for recognizing adat communities in forest areas, with either a regional regulation or decree from a governor, regent, or mayor for recognition in nonforest areas. Meanwhile, recognition of adat land rights hinges on what land management authorities decide. Registration of adat land in forest areas is administered by the National Land Agency, under the Ministry of Agrarian and Spatial Planning Regulation No. 18 of 2019, and the recognition of adat land tenure in forest areas is administered by the KLHK under Regulation No. P17 of 2020 they have to appeal to the very agency that had made those decisions in the first place. Fear of retribution can create another type of conflict of interest. Government officials voiced the concern that they could face retaliation or even criminal charges if they do exercise their authority to resolve land conflicts fairly. If they interfere with the interests of powerful people, they said, they could be accused of maladministration. Thus, under these arrangements, there is a significant risk of a severe conflict of interest for the authorities ostensibly responsible for resolving land conflicts.

\section{Weak Law Enforcement}

Another persistent problem is the failure to enforce the rules or deal with noncompliant licenses. Corruption leads to noncompliant licenses on the ground. For example, according to Nugraha and Jong (2019), the Audit Board of Indonesia has found that oil palm companies that operate without required land rights or outside the permit areas encroach on protected or conservation zones and fail to comply with the licensees' obligations to develop communitybased plantations. Similarly, in the mining sector, 


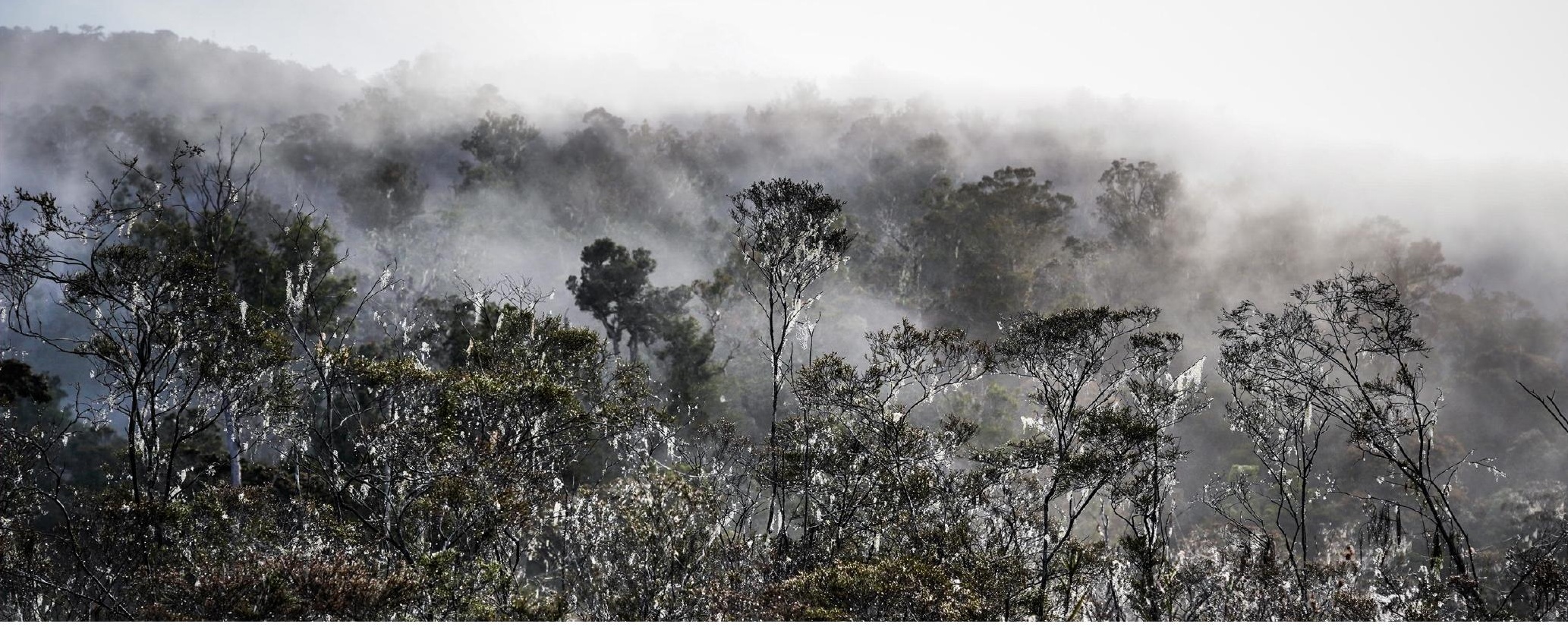

an evaluation led by the Ministry of Energy and Mineral Resources found 4,276 mining licenses that were not clean and clear (out of 10,432), posing legal problems (Tresya et al. 2019). This phenomenon has resulted in demands for greater enforcement of noncompliant licenses to promote justice and equity, especially for those whose land conflicted with the noncompliant licenses.

\section{Land Reform and Conflict Resolution Require Political Will}

Key institutional challenges to resolving land conflicts stem from a bureaucratic culture that is often counterproductive, fractious, and ill-equipped to address intractable structural problems. Bureaucracies may have manpower and expertise, but they cannot be relied on to reform themselves. Bureaucracies perform best when institutions that are accountable through elections provide them with the impetus, specific goals, adequate resources, and sufficient autonomy to solve problems (Meier 1997). Bureaucratic shortcomings often result from deficiencies in one of these factors. Thus, they are not solely symptomatic of administrative failures but are instead the consequences of political decisions. Also, bureaucrats have neither the capacity nor the incentive to make decisions that are inherently fraught and political. Political legitimacy and administrative capacity are both required, and a lack of one or the other can give rise to contradictory objectives, ineffectiveness, and abuses of power.
In Indonesia, the chief shortcomings of land administration systems stem from divided authority and conflicting priorities. Harmonizing and aligning institutions and approaches will require strong political will carried by strong leadership (Burns 2007). This leadership and political will also needs to reach those who interpret and enforce laws and regulations. The government officials whom we interviewed say they need guidance and support from the ministers in charge, especially to resolve conflicts linked to structural problems such as those between communities and state-owned corporations. Resolving land conflicts requires legitimate leadership to mobilize institutions at both the national and local level to collaborate effectively under a coherent strategy. Leadership is vital to build political support for investing in the institutional capacity to resolve conflicts. This includes providing adequate budgeting and necessary incentives to change bureaucratic culture. Legitimate, robust leadership is essential to galvanize efforts to tackle the root causes of land conflicts, including ensuring that requisite and coherent legislation and processes are in place (Srinivas et al. 2015). 


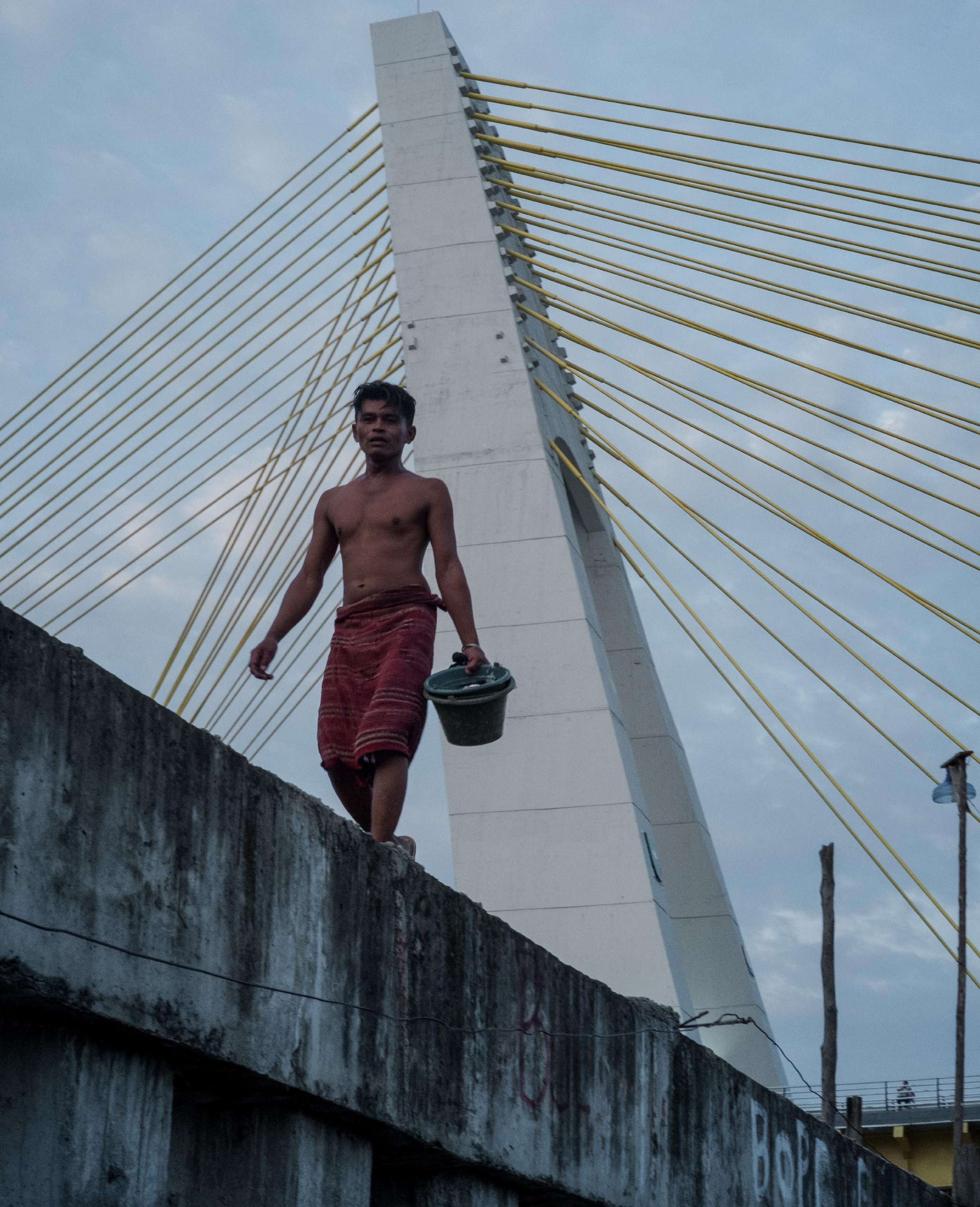




\section{CONCLUSION}

Findings discussed in this report indicate that though the government's initiatives are greatly appreciated, more efforts are needed to overcome institutional barriers. The institutional barriers are likely to block any meaningful progress in resolving land conflicts in Indonesia if left unaddressed. This section presents a few areas of further research and development based on the findings. 
We applaud the Indonesian government's recognition of the depth and breadth of the problem of land conflicts. Its various initiatives, including the One Map Policy, the PPTKH, and the Agrarian Reform Program, are necessary steps forward. However, this report has shown the need for further action to tackle institutional cracks that have provided fertile ground for land conflicts and have stymied efforts to resolve them.

This report finds that despite all the initiatives and programs devised at the national level to resolve land conflicts, the overall response remains reactive, uncoordinated, and not well equipped to deal with their root causes. Scattered authority and complex institutions have left the government without a coherent strategy to address the socioeconomic vulnerabilities that fuel conflicts. Poor, ill-defined operational mechanisms; unskilled workers; inadequate data; insufficient budgets; corruption; and conflicts of interest exacerbate these problems. Political will from top leaders is needed to break down institutional barriers, habits, and biases.

\section{Areas for Further Research and Development}

This report focuses specifically on key institutional barriers to resolving conflicts and identifies several important and relevant areas that require further research and development.

\section{Building political will and support for governance reform}

Implementing the sweeping reforms needed to resolve land conflicts will take political will and legitimacy. Our research reveals that the institutional barriers to resolving land conflicts are quite structural, entrenched, and interwoven. Small fixes will not be adequate. Tackling the source of these conflicts will be difficult because it will mean redirecting national and subnational institutions in the face of resistance and opposition. That requires effective leadership from the president. Further research is required to answer the following questions: What forms must this political will and support take? Where will it come from? Where might it be building, and how can it be harnessed to effectively address the challenges of unclear strategy, poor coordination, and inadequate capacity?

Development of a coherent conflict resolution strategy with built-in coordination mechanisms

Reforms to improve land conflict resolution must begin with a coherent long- and medium-term national plan-a strategy that mitigates conflict and addresses its root causes. It must shift from reactive to systematic approaches. Further research is required to identify the high-priority issues and values that must shape this strategy and enable it to garner collaboration and buy-in from relevant institutions and stakeholders. They must jointly develop performance targets, provide sufficient incentives, and develop more flexible budget and resource-planning schedules. Ultimately, further research is needed to develop strategies and mechanisms for monitoring and evaluation. This plan needs to have teeth to take on the momentous challenges and structural problems that have persisted over many decades and have fueled countless land conflicts.

\section{Land conflict resolution at the subnational level}

Due to decentralization, subnational government bodies play an integral role in land management and governance. As such, they are essential to conflict resolution. However, this report has yet to explore the current conditions faced by these subnational government bodies and how they intersect with the national ones. It is important to examine how the issues highlighted in this report impact the subnational government bodies. Their unique problems may require special attention. Most importantly, for effective land reform, especially in land conflict resolution, strategies must include coordination and capacity building for subnational government bodies. How these strategies can be formulated requires further exploration. 
Development of an integrated land conflict data management system

An integrated land conflict data management system is vital. Without it, Indonesia will struggle to resolve land conflicts and gain a clearer understanding of the structural problems underlying these conflicts. An integrated land administration data set is also necessary for effective conflict resolution and mitigation at the national level. This should include geospatial information on the allocation, rights, and uses of land. The Indonesian government will need to determine how it can integrate geospatial data, collected under the One Map Policy, with nongeospatial land databases that are currently spread among relevant institutions. A more important question is how to encourage more data-driven decision-making processes and transparency, allowing the public to understand the basis of government decisions and plans. We must also investigate how data and technology can nurture necessary innovations for conflict resolution.

\section{Leveraging and consolidating resources}

Further research is required to help the government strategically consolidate its resources and address the lack of resources faced by many institutions. This study could begin by examining which processes could be streamlined and synergized with other activities and which are redundant and inefficient. Innovative financing strategies such as the Village Fund should be examined to address current financial limitations, as should opportunities to utilize existing resources and provide data related to land conflicts, including the National Socioeconomic Survey and the Village Potential Inventory. Further research can help build the capacity and train the workforce needed to resolve conflicts by mapping the necessary skills and expertise required and developing strategies to teach them. Ultimately, greater access to resources must be paired with mechanisms that improve the effectiveness of conflict resolution (CRU 2019). Important subjects to investigate include what forms of models, practices, and standards can be scaled.

\section{Creating robust safeguards to mitigate conflicts of interest and corruption}

Combating corruption is a vital prerequisite for effectively resolving conflicts, but how can a system be developed to provide sufficient accountability throughout the process? Safeguards such as a whistleblower system and complaint-handling mechanism need to be explored. An interesting idea is to invite the KPK to play a greater role in the land conflict resolution process. Other issues of good governance, such as transparency and public participation, will also need to be considered when developing these safeguards.

Ideally, systematically addressing land conflicts would entail reforming land governance. However, we understand that this will be a massive undertaking that will most likely happen incrementally. Thus, we hope the government and land reformers will use this report as a path forward. 


\section{APPENDIX A. DISTRIBUTION MAPPING OF LAND-RELATED RESOLUTION AUTHORITIES}

This section summarizes the regulations that provide authorities for the listed institutions (see also Appendix B).

\section{The KLHK}

Scope of conflict

\section{Membership in ad} hoc teams

\section{Units}

Directorate General of Social Forestry and Environment Partnerships

Directorate General of Forestry Planning and Environmental Management

Directorate General of Law Enforcement

\section{The BPN}

Scope of conflict
Membership in ad
hoc teams
Units

Directorate General of Agrarian Dispute Resolution, Utilization, Space, and Land

Regional Land Agency
- $\quad$ Forest management and tenurial conflicts

- Overlapping spatial plans and/or land-use maps

- One Map Policy Acceleration Team

- PPTKH Acceleration and Implementation Team

- National Agrarian Reform Team

\section{Scope of authorities related to land conflict resolution}

- $\quad$ Setting norms, standards, procedures, and criteria (NSPC); monitoring; evaluating; coordinating; delivering technical support; and supervising social forestry, tenure, adat forests (Hutan adat), and environmental partnership

- Facilitating conflict resolution of forestry, tenure, and adat forest management and environmental partnerships through negotiation, mediation, advocacy, and community assistance

Setting NSPC, monitoring, evaluating, coordinating, delivering technical support, and supervising dispute settlements related to forest area borders and forest area exchanges (changing forest areas to nonforest areas, or vice versa).

- $\quad$ Setting NSPC, monitoring, evaluating, coordinating, delivering technical support, and supervising environmental-related conflict resolution

- Facilitating environmental-related conflict resolution in various natural resources sectors through out-of-court settlement

- Land rights conflicts

- Agrarian disputes and conflicts

- Overlapping spatial plans and/or land-use maps

- One Map Policy Acceleration Team

- PPTKH Acceleration and Implementation Team

- National Agrarian Reform Team and the head of the National Agrarian Reform Task Force; the Regional Land Agency is the operational chief of the Provincial Agrarian Reform Task Force; the district/citylevel Land Agency is the operational chief of the district/city Agrarian Reform Task Force

- Lead authority of the PTSL initiative

\section{Scope of authorities related to land conflict resolution}

- $\quad$ Setting NSPC, monitoring, evaluating, coordinating, delivering technical support, and supervising agrarian/land rights/land use in nonforest area conflicts

- Facilitating resolution of land-related conflicts through mediation and making administrative decisions, which include the following:

- Granting or canceling land rights and/or certificates that are issued by the Regional Land Agency or minister and/or in certain types of disputes or conflicts

- Revoking land rights

- Granting or canceling unused/abandoned lands

- Data amendment on certificates, measuring letters, land books, and/or other general lists

- Notification that there are no administrative errors

Facilitating the settlement of agrarian disputes and land-related conflicts through mediation and making administrative decisions, which include the following:

- Granting or canceling land rights issued by the Land Agency or the Regional Land Agency regarding implementation of court orders

- Data amendment on certificates, measuring letters, land books, and/or other general lists 
Land Agency (at Facilitating the settlement of agrarian disputes and land-related conflicts through mediation and making district/city level) administrative decisions of granting or canceling land rights issued by the Land Agency regarding implementation of court orders

\section{Kemendagri}

\begin{tabular}{|c|c|}
\hline Scope of conflict & $\begin{array}{ll}\text { - } & \text { Social conflicts } \\
\text { - } & \text { Regional border disputes }\end{array}$ \\
\hline $\begin{array}{l}\text { Membership in ad } \\
\text { hoc teams }\end{array}$ & $\begin{array}{l}\text { - } \quad \text { One Map Policy Acceleration Team and the vice head of the Implementation Team } \\
\text { - } \\
\text { - }\end{array}$ \\
\hline Units & Scope of authorities related to land conflict resolution \\
\hline $\begin{array}{l}\text { Directorate General } \\
\text { of Politics and Public } \\
\text { Administration }\end{array}$ & 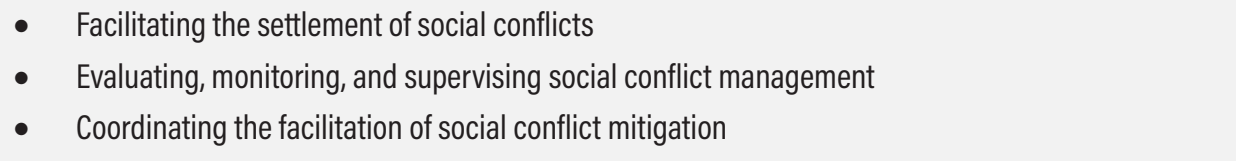 \\
\hline $\begin{array}{l}\text { Directorate General } \\
\text { of Regional } \\
\text { Administration } \\
\text { Development }\end{array}$ & $\begin{array}{l}\text { - Monitoring, evaluating, coordinating, delivering technical support, and supervising regional border } \\
\text { disputes } \\
\text { - } \quad \text { Facilitating the settlement of regional border disputes }\end{array}$ \\
\hline
\end{tabular}

\section{Kementan}

\section{Scope of conflict}

Membership in ad hoc teams

Units

Directorate General of Plantations
- Conflicts that disrupt plantation businesses

- National Agrarian Reform Team and the National Agrarian Reform Task Force

\section{Scope of Authorities related to Land Conflict Resolution}

Developing a conflict resolution framework in plantation areas and facilitating conflict resolution concerning the protection of plantation business

Kemenko Perekonomian

Scope of conflict
Membership in ad
hoc teams
Units
Coordinator Deputy
of Energy, Natural
Resources, and
Environmental
Management

Coordinator Deputy of Infrastructure, Acceleration, and Territorial Development
Indirect

- Head of the One Map Policy Acceleration Team and the secretary of the Implementation Team

- Head of the PPTKH Acceleration Team and the head and the secretary of the Implementation Team

- Head of the National Agrarian Reform Team and the vice head of the National Agrarian Reform Task Force

\section{Scope of authorities related to land conflict resolution}

- Coordinating and synchronizing policymaking and its implementation under several land-related authorities concerning energy, natural resources, and environmental management, including the KLHK, the BPN, and Kementan

- Controlling policy implementation under these authorities

- Under Presidential Regulation No. 88 of 2017 on the Land Tenure Settlement in the Forest Areas, this deputy is mandated to be the head of the Implementation Team of the Acceleration Team of the PPTKH; however, Presidential Regulation No. 37 of 2020 on the Coordinating Ministry for Economic Affairs eliminates this deputy

- Coordinating and synchronizing policymaking and its implementation under several land-related authorities concerning infrastructure and territorial development, including the KLHK, the BPN, and Kementan

- Controlling the policy implementation under these land authorities

- Under Presidential Regulation No. 88 of 2017 on the Land Tenure Settlement in the Forest Areas, this deputy is mandated to be the head of the Implementation Team of the Acceleration Team of the PPTKH. However, Presidential Regulation No. 37 of 2020 on the Coordinating Ministry of Economic Affairs eliminates this deputy 
Coordinator Deputy of Regional Development and Spatial Planning
- Coordinating and synchronizing policymaking and its implementation under several land-related authorities concerning regional development and spatial planning, including the Ministry of Agrarian and Spatial Planning/BPN and Kementan

- Controlling the policy implementation under these land authorities

- This deputy is not mentioned in Presidential Regulation No. 88 of 2017 on the Land Tenure Settlement in the Forest Areas as the Implementation Team; however, it is the most relevant deputy that relates to land-related conflict resolution, according to Presidential Regulation No. 37 of 2020 on the Coordinating Ministry for Economic Affairs

Kemenhan

Scope of conflict

- Social conflicts

\section{Scope of authorities related to land conflict resolution}

- Delivering administrative support and making recommendations to the president relating to the deployment of the national military to mitigate a national-scale conflict

- Monitoring and evaluating the implementation of social conflict mitigation

Kemenko Polhukam

Scope of conflict Social conflicts

\section{Scope of authorities related to land conflict resolution}

Coordinating and synchronizing the formulation and implementation of policy on social conflict resolution

The KSP

$\begin{array}{ll}\text { Scope of conflict } & \text { Forest management and tenurial conflicts; rights conflicts } \\ \text { Membership in ad } & \text { - Vice secretary of the One Map Policy Acceleration Team } \\ \text { hoc teams } & \text { - } \quad \text { PPTKH Implementation Team } \\ & \text { - National Agrarian Reform Task Force }\end{array}$

\section{Scope of authorities related to land conflict resolution}

- Controlling national priority programs to ensure its conformity with the president's visions and missions

- Delivering assistance to accelerate the implementation of national priority programs and strategic issues

- Settling problems in national priority programs if it has encountered obstacles within its implementation

- Monitoring and evaluating the implementation of national priority programs and strategic issues

- Providing data analysis and strategic information in decision-making

- $\quad$ Other tasks, as instructed by the president

- For certain cases, it can establish special teams or task forces across relevant ministries and/or institutions

- Basically, the power of the KSP depends on whether conflict resolution is set as a national priority program and/or direct instruction from the president

- In these cases, the KSP established the Team for Accelerating the Agrarian Conflict Resolution in 2017 that is mandated to
○ receive complaints;
○ analyze cases; and
○ organize coordination meetings and provide recommendations for resolving agrarian conflicts

Ombudsman

$\begin{array}{ll}\text { Scope of conflict } & \text { Indirect } \\ \text { Units } & \text { Scope of authorities related to land conflict resolution }\end{array}$

Overseeing the implementation of public services by authorities, including those that are related to conflict resolution; it has the power to conduct investigations into issues of maladministration-either on its own initiative or in response to reports submitted by the public; in these latter cases, the Ombudsman has the power to facilitate mediation and conciliation between parties; as a result, the 0mbudsman may issue a report containing its findings and make recommendations to the president, the House of Representatives, and related institutional leaders 
Komnas HAM

Scope of conflict

Conflicts that contain human rights violations

\section{Scope of authorities related to land conflict resolution}

Conducting research, capacity building, monitoring, and facilitating mediation for enforcing human rights in Indonesia; Komnas HAM also has the power to investigate any case involving serious human rights violations; in such cases, Komnas HAM may form an ad hoc team that includes CSO representatives to focus on investigating the case; as a result, Komnas HAM may issue a report that includes findings and recommendations for government ministries and the House of Representatives; in the context of land-related conflict resolution, Komnas HAM may exercise its power to address human rights violations in conflict

Indonesian National Police

$\begin{array}{lll}\text { Scope of conflict } & \text { - Social conflicts } \\ & \text { - } & \text { Conflicts with wide-scale physical violence }\end{array}$

Membership in ad National Agrarian Reform Team

hoc teams

Scope of authorities related to land conflict resolution

Quelling rioting/physical violence in a conflict situation and coordinating with the Indonesian National Armed Forces for military assistance when necessary

Indonesian National Armed Forces

$\begin{array}{ll}\text { Scope of conflict } & \bullet \quad \text { Social conflicts } \\ \begin{array}{l}\text { Membership in ad } \\ \text { hoc teams }\end{array} & \text { National Agrarian Reform Team }\end{array}$

\section{Scope of authorities related to land conflict resolution}

Deploying military assistance to quell widespread violence in a conflict situation

Ad hoc teams established by the Presidential Regulation on the One Map Policy

Scope of conflict

Teams

Acceleration Team of the One Map Policy

Implementation Team of the One Map Policy

Secretariat of the Acceleration Team
Overlapping maps of spatial plans and/or land use

\section{Scope of authorities related to land conflict resolution}

- Monitoring, evaluating, and implementing the acceleration of the One Map Policy, including synchronizing overlapping maps

- Conducting the strategic coordination needed to accelerate the implementation of the One Map Policy

- Establishing policies to resolve any obstacles to the One Map Policy

- Setting the framework for the Implementation Team following the objectives of the acceleration of the One Map Policy

- $\quad$ Reporting to the president

- Assisting the Acceleration Team in conducting technical coordination, monitoring, and evaluation of the implementation of the action plan for accelerating the One Map Policy

- Assisting the Acceleration Team in establishing measures and policies to resolve problems and technical obstacles to accelerate the One Map Policy

- $\quad$ Assisting the Acceleration Team in establishing priority measures and actions as well as data-sharing mechanisms within map-holding institutions

Providing support, technical-operational services, and administrative services for the Acceleration Team and the Implementation Team, including the following:

- Inventorying and compiling map databases under related institutions

- Integrating the maps under one standard

- $\quad$ Synchronizing overlapping maps

- Providing recommendations on resolving problems related to synchronization

- Developing resolution systems for overlapping maps

- $\quad$ Supporting technical coordination between related institutions 
Ad hoc teams established by the BPN to implement the Presidential Instruction on PTSL

\begin{tabular}{|c|c|}
\hline Scope of conflict & Overlapping landownership or claims \\
\hline Units & Scope of authorities related to land conflict resolution \\
\hline $\begin{array}{l}\text { Adjudication } \\
\text { Committee }\end{array}$ & $\begin{array}{l}\text { - } \text { Developing a scheme of work for the execution of PTSL } \\
\text { - } \quad \text { Collecting and verifying data and evidence for landownership or claims } \\
\text { - } \quad \text { Facilitating dispute resolution between conflicting parties over land } \\
\text { - } \quad \text { Sulidating data and evidence as to the basis for granting rights and rights registration } \\
\text { - }\end{array}$ \\
\hline $\begin{array}{l}\text { Task Force for Physical } \\
\text { Data }\end{array}$ & $\begin{array}{l}\text { Assisting the Adjudication Committee in collecting and verifying physical data, including mapping land } \\
\text { plots }\end{array}$ \\
\hline $\begin{array}{l}\text { Task Force for Juridical } \\
\text { Data }\end{array}$ & $\begin{array}{l}\text { Assisting the Adjudication Committee in collecting and verifying juridical data, including following up on } \\
\text { objections from third parties }\end{array}$ \\
\hline $\begin{array}{l}\text { Task Force for } \\
\text { Administration }\end{array}$ & Assisting the secretary of the Adjudication Committee with administrative tasks \\
\hline \multicolumn{2}{|c|}{ Ad hoc teams established by the Presidential Regulation on the Land Tenure Settlement in the Forest Areas } \\
\hline Scope of conflict & Land tenure disputes in forest areas \\
\hline Teams & Scope of authorities related to land conflict resolution \\
\hline $\begin{array}{l}\text { PPTKH Acceleration } \\
\text { Team }\end{array}$ & $\begin{array}{l}\text { - } \text { Coordinating, synchronizing, monitoring, and controlling the implementation of land tenure } \\
\text { - } \quad \text { Esttlements in forest areas } \\
\text { tenure settlements in forest areas } \\
\text { - } \quad \text { Determining the maximum land area that is permissible for a settlement in forest areas } \\
\text { - } \quad \text { Establishing resettlement mechanisms } \\
\text { - } \quad \text { Budgeting facilitation } \\
\text { - } \quad \text { Reporting to the president }\end{array}$ \\
\hline $\begin{array}{l}\text { PPTKH Implementation } \\
\text { Team }\end{array}$ & $\begin{array}{l}\text { - Technical coordination for the implementation of land tenure settlements in forest areas } \\
\text { - Developing measures required to implement tenure settlements in forest areas } \\
\text { - Assisting the Acceleration Team in the implementation of supervision and control over the land tenure } \\
\text { settlements in forest areas } \\
\text { - Developing problem-solving recommendations for the implementation of land tenure settlements in } \\
\text { forest areas and delivering these recommendations to the Acceleration Team }\end{array}$ \\
\hline $\begin{array}{l}\text { PPTKH Inventory and } \\
\text { Verification Team (at } \\
\text { the provincial level) }\end{array}$ & $\begin{array}{l}\text { - } \quad \text { Collecting requested inventories and verification submitted collectively through mayors } \\
\text { - } \quad \text { Collecting on-the-ground data } \\
\text { - } \quad \text { Analyzing physical and juridical data in forest areas as well as analyzing environmental issues } \\
\text { - } \quad \text { Developing and delivering recommendations to governors }\end{array}$ \\
\hline
\end{tabular}


Ad hoc teams established by the Presidential Regulation on Agrarian Reform

\begin{tabular}{|c|c|}
\hline Scope of conflict & Agrarian disputes and conflicts \\
\hline Units & Scope of authorities related to land conflict resolution \\
\hline $\begin{array}{l}\text { National Agrarian } \\
\text { Reform Team }\end{array}$ & $\begin{array}{l}\text { - } \quad \text { Establishing policies and plans for agrarian reform } \\
\text { - } \quad \text { Coordinating and resolving obstacles in the implementation of agrarian reform } \\
\text { - } \quad \text { Supervising the implementation of agrarian reform and reporting to the president }\end{array}$ \\
\hline $\begin{array}{l}\text { National Agrarian } \\
\text { Reform Task Force }\end{array}$ & $\begin{array}{l}\text { - Coordinating, facilitating, and integrating the implementation of agrarian reform at the national level } \\
\text { - } \quad \text { Coordinating and facilitating the settlement of agrarian disputes and conflicts } \\
\text { - Monitoring task implementation by provincial task forces and district/city task forces } \\
\text { - } \quad \text { Reporting the results of agrarian reform to the National Agrarian Reform Team }\end{array}$ \\
\hline $\begin{array}{l}\text { Provincial Agrarian } \\
\text { Reform Task Force }\end{array}$ & $\begin{array}{l}\text { - Coordinating, facilitating, and integrating the implementation of agrarian reform at the provincial level } \\
\text { - } \quad \text { Coordinating and facilitating the settlement of agrarian disputes and conflicts at the provincial level } \\
\text { - } \quad \text { Strengthening the capacity of agrarian reform at the provincial level } \\
\text { - } \quad \text { Reporting the results of agrarian reform to the National Agrarian Reform Task Force }\end{array}$ \\
\hline $\begin{array}{l}\text { Regency/City Agrarian } \\
\text { Reform Task Force }\end{array}$ & $\begin{array}{l}\text { - Implementing agrarian reform } \\
\text { - Strengthening the capacity of agrarian reform at the district/city level } \\
\text { - } \quad \text { Coordinating and facilitating the settlement of agrarian disputes and conflicts at the district/city level } \\
\text { - } \quad \text { Menitoring task implementation of land redistribution and legalization }\end{array}$ \\
\hline
\end{tabular}




\section{APPENDIX B. LIST OF LAWS AND REGULATIONS}

\section{The Constitution and Laws}

1. 1945 Constitution of Indonesia

2. Basic Agrarian Law No. 5 of 1960

3. Basic Forestry Law No. 5 of 1967

4. Basic Mining Law No. 11 of 1967

5. Abolishment of Land Reform Court Law No. 7 of 1970

6. Human Rights Law No. 39 of 1999

7. Forestry Law No. 41 of 1999

8. Oil and Gas Law No. 22 of 2001

9. National Police Law No. 2 of 2002

10. Regional Administration Law No. 32 of 2004

11. National Armed Forces of Indonesia Law No. 34 of 2004

12. Spatial Planning Law No. 26 of 2007

13. Coastal Area and Small Islands Law No. 27 of 2007

14. Ombudsman Law No. 37 of 2008

15. Mineral and Coal Mining Law No. 4 of 2009

16. Horticulture Law No. 13 of 2010

17. Land Procurement for Public Interest Construction Law No. 2 of 2012

18. Social Conflict Law No. 7 of 2012

19. Law No. 1 of 2014 on the Amendment of Law No. 27 of 2007 on Coastal Area and Small Islands

20. Geothermal Energy Law No. 21 of 2014

21. Regional Administration Law No. 23 of 2014

22. Plantation Law No. 39 of 2014

\section{Government and Presidential Regulations}

1. Government Regulation No. 24 of 1997 on Land Registration

2. Government Regulation No. 22 of 2010 on Mining Areas

3. Presidential Regulation No. 11 of 2015 on Ministry of Home Affairs

4. Presidential Regulation No. 16 of 2015 on Ministry of Environment and Forestry

5. Presidential Regulation No. 45 of 2015 on Ministry of Agriculture

6. Presidential Regulation No, 43 of 2015 on Coordinating Ministry for Political, Legal, and Security of Indonesia

7. Presidential Regulation No. 8 of 2015 on Coordinating Ministry for Economic Affairs

8. Presidential Regulation No. 17 of 2015 on Ministry of Agrarian and Spatial Planning/National Land Agency

9. Presidential Regulation No. 9 of 2016 on the Acceleration of the One Map Policy

10. Presidential Regulation No. 88 of 2017 on the Land Tenure Settlement in the Forest Areas

11. Presidential Regulation No. 86 of 2018 on Agrarian Reform

\section{Ministerial Regulations}

1. Ministry of Home Affairs Regulation No. 18 of 2015 on Organization and Working Procedures (as Amended for the Last Time by Ministry of Home Affairs Regulation No. 8 of 2018)

2. Ministry of Agrarian and Spatial Planning/National Land Agency Regulation No. 8 of 2015 on Organization and Working Procedures (as Amended by Ministry of Agrarian and Spatial Planning /National Land Agency No. 1 of 2019)

3. Ministry of Environment and Forestry Regulation No. 18 of 2015 on Organization and Working Procedures (as Amended by Ministry of Environment and Forestry Regulation No. 1 of 2019)

4. Ministry of Agriculture Regulation No. 43 of 2015 on Organization and Working Procedures

5. Ministry of Defense Regulation No. 13 of 2016 on Deployment and Utilization Assistance of the Indonesian National Armed Forces in Social Conflicts

6. Ministry of Environment and Forestry Regulation No. P.83 of 2016 on Social Forestry.

7. Ministry of Agrarian and Spatial Planning /National Land Agency Regulation No. 17 of 2019 on Location Permit

8. Ministry of Energy and Mineral Resources Regulation No. 7 of 2020 on Procedures for Issuing Areas, Licenses, and Reports on Mineral and Coal Mining Business Activity

\section{Other Regulations}

1. Head of President's Executive Office Decree No. 9 of 2017 on the Establishment of the Agrarian Conflict Resolution Acceleration Team 


\section{ABBREVIATIONS}

BAL

BPN

CSO

Ditjen PSKL

FGD

Kemendagri Kementerian Dalam Negeri (Ministry of Home Affairs)

Kemenhan Kementerian Pertahanan (Ministry of Defense)

Kemenko Kementerian Koordinator Bidang Perekonomian

Perekonomian (Coordinating Ministry for Economic Affairs)

Kemenko Kementerian Koordinator Bidang Politik, Hukum,

Polhukam dan Keamanan (Coordinating Ministry for Political, Legal, and Security Affairs)

Kementan Kementerian Pertanian (Ministry of Agriculture)

KLHK Kementerian Lingkungan Hidup dan Kehutanan (Ministry of Environment and Forestry)

Komnas HAM Komisi Nasional Hak Asasi Manusia (National Commission on Human Rights)

KPA

KPK Komisi Pemberantasan Korupsi (Corruption Eradication Commission)

KSP Kantor Staf Presiden (President's Executive Office)

NSPC

PKTHA Direktorat Pengaduan Konflik, Tenurial dan Hutan Adat (Directorate of Tenurial and Adat Forest Conflict Complaints)

PTSL Pendaftaran Tanah Sistematis Lengkap (Complete Systematic Registration of Land)

\section{ENDNOTES}

1. During this period, foreigners were subject to a civil code that was modeled on the Western tenurial system, and various adat, or customary laws, were applied to Indonesians. This continued even after independence, with the result that less than 5 percent of land was registered and titled, leaving the rest untitled but recognized under various semiformal tenurial arrangements. See MacAndrews $(1986,19-20)$ for further information.

2. Suharto and his allies benefited from weak tenure systems. The ownership was used for economic advancement and political survival, and there was growing pressure for more secure land titles.

3. For additional information, see the consideration section of Law No. 7 of 1970 on the Abolition of the Land Reform Court.

4. At the end of November 2020, the BPN replaced this regulation with the new minister's Regulation No. 21 of 2020. This regulation was not reviewed by this paper because it was issued after this paper had passed its peer review process.

5. Social conflict is legally defined as a feud or physical clash that involves violence between two or more groups of people or communities that lasts for a certain period and has a widespread impact that may result in diminishing security and lead to social disintegration that will, in turn, affect national stability and hamper development.

6. At the end of November 2020, the BPN replaced this regulation with the new minister's Regulation No. 21 of 2020. This regulation was not reviewed by this paper because it was issued after this paper had passed its peer review process.

7. See also UN DESA $(2005,40,106)$. 


\section{REFERENCES}

Abood, S.A., J.S.H. Lee, Z. Burivalova, J. Garcia-Ulloa, and L.P. Koh. 2015. "Relative Contributions of the Logging, Fiber, Oil Palm, and Mining Industries to Forest Loss in Indonesia." Conservation Letters 8 (1): 58-67. https://doi.org/10.1111/conl.12103.

Adam, A.W. 2015. "How Indonesia's 1965-1966 Anti-Communist Purge Remade a Nation and the World." The Conversation, September 30. http://theconversation.com/how-indonesias1965-1966-anti-communist-purge-remade-a-nation-and-theworld-48243.

Affandi, D.Y. 2017, "The Struggle over Adat Forest Rights in Upland Banten, Indonesia." PhD diss, Monash University. https://bridges, monash.edu/articles/thesis/The_Struggle_over_Adat_Forest_ Rights_in_Upland_Banten_Indonesia/4892138/2.

Afiff, S., and C. Lowe. 2007. "Claiming Indigenous Community: Political Discourse and Natural Resource Rights in Indonesia." Alternatives 32 (1): 73-97. https://doi. org/10.1177/030437540703200104.

Akhir, D.J. 2015. "Mendagri: Mau Jadi Bupati, Siapkan Rp75 Miliar." Okezone.com, October 22. https://nasional.okezone. com/read/2015/10/22/337/1236291/mendagri-mau-jadi-bupatisiapkan-rp75-miliar.

Andrews-Speed, P., R. Bleischwitz, T. Boersma, C. Johnson, G. Kemp, and S.D. VanDeveer. 2012. The Global Resource Nexus: The Struggles for Land, Energy, Food, Water, and Minerals. Washington, DC: Transatlantic Academy. https://www.gmfus.org/ publications/global-resource-nexus-struggles-land-energy-foodwater-and-minerals.

Arnold, L.L. 2008. "Deforestation in Decentralised Indonesia: What's Law Got to Do with It?" Law Environment and Development Journal 4 (2): 75-101. http://lead-journal.org/ content/08075.pdf.

Bachriadi, D., and G. Wiradi. 2014. "Land Concentration and Land Reform in Indonesia: Interpreting Agricultural Census Data, 1963-2003." In Land for the People: The State and Agrarian Conflict in Indonesia, edited by A. Lucas and C. Warren. Athens: Ohio University Press. https://www.jstor.org/stable/j.ctt46n3nz.

Barreiro, V., M. Iqbal, G. Limberg, A. Sileuw, and J. Schweithelm. 2016. "The Cost of Conflict in Oil Palm in Indonesia." Jakarta: Conflict Resolution Unit, Indonesia Business Council for Sustainable Development, https://daemeter.org/new/ uploads/20170121193336.The_Cost_of_Conflict_in_Oil_Palm_ Indonesia_.pdf.

Bernauer, T., T. Böhmelt, and V. Koubi. 2012. "Environmental Changes and Violent Conflict." Environmental Research Letters 7 (1): 015601. https://doi.org/10.1088/1748-9326/7/1/015601.

BPS (Badan Pusat Statistika). 2020a. "Indonesian 0il Palm Statistics 2019." Jakarta: BPS. https://www.bps.go.id/publication /2020/11/30/36cba77a73179202def4ba14/statistik-kelapa-sawitindonesia-2019.html.
BPS. 2020b. Labor Force Situation in Indonesia August 2020. Publication 04120.2005. Jakarta: BPS. https://www.bps.go.id/ publication/2020/11/30/307a288d678f91b9be362021/keadaanangkatan-kerja-di-indonesia-agustus-2020.html.

Brown, 0, and M. Keating. 2015. Addressing Natural Resource Conflicts: Working towards More Effective Resolution of National and Sub-national Resource Disputes. London: Chatham House: Royal Institute of International Affairs. https://www. chathamhouse.org/publication/addressing-natural-resource-con flicts/20150619AddressingConflictResourcesBrownKeating.pdf.

Burns, T. 2007. "Land Administration Reform: Indicators of Success and Future Challenges." Working Paper 41893. Washington, DC: World Bank. http://documents.worldbank.org/ curated/en/771101468160190062/Land-administration-reformindicators-of-success-and-future-challenges.

Campbell, J.Y. 2002. "Differing Perspectives on Community Forestry in Indonesia." In Which Way Forward? People, Forests, and Policymaking in Indonesia, edited by C.J. Pierce Colfer and I.A.P. Resosudarmo. Washington, DC: Resources for the Future.

Colmey, J., and D. Liebhold. 1999. "Suharto Inc.: All in the Family." Probe International (blog), May 24. https://journal. probeinternational.org/1999/05/24/suharto-inc-all-family/.

Contreras-Hermosilla, A., and C. Fay. 2005. Strengthening Forest Management in Indonesia through Land Tenure Reform: Issues and Framework for Action. Washington, DC: Forest Trends. https://www.forest-trends.org/wp-content/uploads/imported/ IndonesiaReport_final_11-4.pdf.

Coser, L.A. 1957. "Social Conflict and the Theory of Social Change." British Journal of Sociology 8 (3): 197-207. https://doi. org/10.2307/586859.

CRU (Conflict Resolution Unit). 2019. Panduan Praktis Penanganan Konflik Berbasis Lahan. Jakarta: CRU, Indonesia Business Council for Sustainable Development. https://www. conflictresolutionunit.id/wp-content/uploads/2019/03/CRU. Panduan-Penanganan-Konflik-Berbasis-Lahan.29Nov2018.pdf.

Dasandi, N., D. Hudson, and T. Pegram. 2015. "Governance and Institutions." In Thinking Beyond Sectors for Sustainable Development, edited by J. Waage and C. Yap, 63-76. London: Ubiquity. https://doi.org/10.5334/bao.h.

Davis, $R_{1}$, and D. Franks. 2014. Costs of Company-Community Conflict in the Extractive Sector. Cambridge, MA: Corporate Social Responsibility Initiative, Harvard Kennedy School. https://www. csrm.uq.edu.au/media/docs/603/Costs_of_Conflict_DavisFranks.pdf.

Earth Innovation Institute. 2015. Central Kalimantan Land Governance Assessment. Washington, DC: World Bank. https:// openknowledge.worldbank.org/handle/10986/28514.

Enemark, S. 2009. "Land Governance: Supporting the Global Agenda and Serving Society." Presented at the Olumide Memorial Lecture, Nigeria Institution of Surveyors, Abuja, Nigeria, October 29. http://w.fig.net/news/archive/news_2009/nigeria_ october_2009/Nigeria-paper-2009.pdf. 
Fay, C., and M. Sirait. 2002. "Reforming the Reformists in PostSoeharto Indonesia." In Which Way Forward: People, Forests, and Policymaking in Indonesia, edited by C.J. Pierce Colfer and I.A.P. Resosudarmo. Washington, DC: Resources for the Future.

FoE (Friends of the Earth), LifeMosaic, and Sawit Watch. 2008. Losing Ground: The Human Rights Impacts of Oil Palm Plantation Expansion in Indonesia. London: FoE, Edinburgh: LifeMosaic, and Bogor: Sawit Watch. https://www.foei.org/wp-content/ uploads/2014/08/losingground.pdf.

Forst, M. 2014، "Strengthening Inter-institutional Coordination: Perspectives from the OECD." Presented at the Second International Seminar of the Organization of American States, "Innovative Experiences in Effective Public Management," Panama City, March 14. https://www.oas.org/en/spa/depm/ seminarios/panama/default.asp.

Gaveau, D.L.A., D. Sheil, Husnayaen, M.A. Salim, S. Arjasakusuma, M. Ancrenaz, P. Pacheco, and E. Meijaard. 2016. "Rapid Conversions and Avoided Deforestation: Examining Four Decades of Industrial Plantation Expansion in Borneo." Scientific Reports 6 (September): 32017. https://doi.org/10.1038/srep32017.

Gecko Project and Mongabay. 2017a. "Introducing: Indonesia for Sale." October 10. https://thegeckoproject.org/introducingindonesia-for-sale-3acc3eaalb7d.

Gecko Project and Mongabay. 2017b. "The Making of a Palm Oil Fiefdom." October 11. https://thegeckoproject.org/the-making-ofa-palm-oil-fiefdom-7e1014e8c342.

Gecko Project and Mongabay. 2018a. "Analysis: Does Indonesia's Storied Anti-graft Agency Have a Blind Spot for Corrupt Land Deals?" August 21. https://thegeckoproject.org/analysis-doesindonesias-vaunted-anti-graft-agency-have-a-blind-spot-forcorrupt-land-deals-67e482b2f551.

Gecko Project and Mongabay. 2018b. "Ghosts in the Machine." April 18. https://thegeckoproject.org/ghosts-in-the-machine$4 a c b 5 c 5236 c c$.

Gecko Project and Mongabay. 2018c. "How Corrupt Elections Fuel the Sell-Off of Indonesia's Natural Resources." June 7. https:// thegeckoproject.org/how-corrupt-elections-fuel-the-sell-off-ofindonesias-natural-resources-c9ae7521d0ee.

Gecko Project and Mongabay. 2018d. "Comment: It's Time to Confront the Collusion between the Palm Oil Industry and Politicians That Is Driving Indonesia's Deforestation Crisis." April 18. https://thegeckoproject.org/comment-its-time-to-confrontthe-collusion-between-the-palm-oil-industry-and-politiciansthat-is-6149ae12636f.

Gecko Project and Mongabay. 2018e. "'North Sumatran Land Mafia Offered Me \$21m to Win Election-Then Hand Over Control of Government."' June 21. https://thegeckoproject.org/northsumatran-land-mafia-offered-me-21m-to-win-election-thenhand-over-control-of-government-4a4b40f5b7e5.

Gecko Project and Mongabay. 2019a. "How Land Grabbers Weaponise Indigenous Ritual against Papuans: An Interview with Anthropologist Sophie Chao." March 28. https://thegeckoproject. org/how-land-grabbers-weaponise-indigenous-ritual-againstpapuans-an-interview-with-anthropologist-7ebf8ee34385.
Gecko Project and Mongabay. 2019b. "What We Learned from Two Years of Investigating Corrupt Land Deals in Indonesia." May 8. https://thegeckoproject.org/what-we-learned-from-two-yearsof-investigating-corrupt-land-deals-in-indonesia-17988e27e981.

Gol (Government of Indonesia). 2014، Rencana Pembangunan Jangka Menengah Nasional (RPJMN) 2015-2019. Jakarta: Ministry of National Development Planning, Gol.

\section{Gol. 2015. Rencana Strategis Direktorat Jenderal Perhutanan Sosial dan Kemitraan Lingkungan 2015-2019. P.11/PSKL- SETDIT/2015. Jakarta: Ministry of the Environment and Forestry, Gol. https://www.menlhk.go.id/site/single_post/1591.}

Gol. 2017a. Laporan Tahunan Komnas HAM 2016: Pemenuhan Hak Kelompok Minoritas dan Rentan di Indonesia. Annual Report. Jakarta: Komisi Nasional Hak Asasi Manusia, Gol. https://www. komnasham.go.id/index.php/laporan/36/laporan-tahunankomnas-ham-tahun-2016.html.

Gol. 2017b. Rapat Koordinasi Nasional Percepatan Pelaksanaan Kebijakan Satu Peta, "Satu Peta Untuk Pembangunan Nasional," Kementerian Koordinator Bidang Perekonomian, Jakarta, October 26.

Gol. 2019a. "Komnas HAM Dorong Penyelesaian Konflik Agraria Ham." Komisi Nasional Hak Asasi Manusia, December 12. https:// www.komnasham.go.id/index.php/news/2019/12/12/1279/ komnas-ham-dorong-penyelesaian-konflik-agraria-ham.html.

Gol. 2019b. "Menteri ATR/Kepala BPN: Hanya Ada 8.959 Sengketa Kasus Tanah," Sekretariat Kabinet Republik Indonesia, May 3. https://setkab.go.id/menteri-atrkepala-bpn-hanya-ada-8-959sengketa-kasus-tanah/.

Gol. 2020. Laporan Kinerja. Jakarta: Kementerian Agraria dan Tata Ruang/Badan Pertanahan Nasional, Gol, https://www.atrbpn. go.id/unduh/laporanKinerja2019.pdf.

Gol. 2020b. "Statistik Ditjen PSKL." Jakarta: Kementerian Lingkungan Hidup dan Kehutanan, Gol.

Greenpeace, Jaringan Advokasi Tambang, Indonesia Corruption Watch, and Auriga. 2019. Coalruption: Elite Politik dalam Pusaran Bisnis Batu Bara. Jakarta: Greenpeace, Jaringan Advokasi Tambang, Indonesia Corruption Watch, and Auriga. https://storage.googleapis.com/planet4-indonesiastateless/2019/02/23752c04-23752c04-coalruption_indonesia_ web.pdf.

Gumilang, P. 2016. "'Perang' TNI AD dan Warga di Konflik Lahan Tanah Kusir." CNN Indonesia, September 6. www.cnnindonesia. com/nasional/20160906103553-20-156348/perang-tni-ad-danwarga-di-konflik-lahan-tanah-kusir.

Hackenbruch, M., and J.D. Pluess. 2011. Commercial Value from Sustainable Local Benefits in the Extractive Industries: Local Content. New York: Business for Social Responsibility. http:// www.bsr.org/reports/BSR_LocalContent_March2011.pdf.

Hartmann, B. 2001. "Will the Circle Be Unbroken? A Critique of the Project on Environment, Population, and Security." In Violent Environments, by N.L. Peluso and M. Watts, 464. Ithaca, NY: Cornell University Press. 
IPAC (Institute for Policy Analysis of Conflict). 2013. "Land and Resource Disputes." http://www.understandingconflict.org/en/ conflict/index/3/Land-and-Resource-Disputes.

IRIN News. 2010. "Demand for Palm Oil Fuels Land-Grabbing." New Humanitarian, July 6. https://www.thenewhumanitarian.org/ news/2010/07/06/demand-palm-oil-fuels-land-grabbing.

Jakarta Post. 2019. "Jokowi Saves Forests, but Fails to Resolve Land, Mining Conflicts." February 17. https://www.thejakartapost. com/news/2019/02/13/jokowi-saves-forests-but-fails-to-resolveland-mining-conflicts.html.

Johnson, T. 2015. "Palm Oil Companies Exploit Indonesia's People and Its Corrupt Politics." The Guardian, June 11. https://www. theguardian.com/sustainable-business/2015/jun/11/palm-oilindustry-indonesia-corruption-communities-forests.

Keefer, P. 2002. "The Political Economy of Corruption in Indonesia." Washington, DC: World Bank. http://www1. worldbank.org/publicsector/anticorrupt/FlagshipCourse2003/ KeeferIndonesia.pdf.

Kiswanto, D. 2017. "What Local Official Arrests Tell Us about Indonesian Political System." Jakarta Post, October 12. https:// www.thejakartapost.com/academia/2017/10/12/what-localofficial-arrests-tell-us-about-indonesian-political-system.html.

KPA (Konsorsium Pembaruan Agraria). 2010. Laporan Akhir Tahun Konsorsium Pembaruan Agraria 2009. Jakarta: KPA. http:// kpa.or.id/publikasi/baca/laporan/64/Laporan_Akhir_Tahun_ Konsorsium_Pembaruan_Agraria_2009/.

KPA. 2011. Laporan Akhir Tahun 2010 Konsorsium Pembaruan Agraria: Tahun Agraria Nasional, Tahun Duka Petani. Jakarta: KPA. http://kpa.or.id/publikasi/baca/laporan/65/Laporan_Akhir_ Tahun_2010_KPA:_Tahun_Agraria_Nasional__Tahun_Duka_ Petani/.

KPA. 2012. Laporan Akhir Tahun 2011 Konsorsium Pembaruan Agraria: Tahun Perampasan Tanah dan Kekerasan Terhadap Petani. Jakarta: KPA. http://kpa.or.id/publikasi/baca/laporan/66/ Laporan_Akhir_Tahun_2011_KPA:_Tahun_Perampasan_ Tanah_dan_Kekerasan_Terhadap_Petani/.

KPA. 2013. Laporan Akhir Tahun 2012: Terkuburnya Keadilan Bagi Rakyat Melalui Reforma Agraria. Jakarta: KPA. http://kpa. or.id/publikasi/baca/laporan/67/Laporan_Akhir_Tahun_2012:_ Terkuburnya_Keadilan_Bagi_Rakyat_Melalui_Reforma_ Agraria/.

KPA. 2014. Laporan Akhir Tahun 2013 Konsorsium Pembaruan Agrara: Warisan Buruk Masalah Agraria di Bawah Kekuasaan SBY, Jakarta: KPA. http://kpa.or.id/publikasi/baca/laporan/68/ Laporan_Akhir_Tahun_2013_KPA:_Warisan_Buruk_Masalah_ Agraria_di_Bawah_Ke-kuasaan_SBYY/.

KPA. 2015. "Korupsi Agraria Memiskinkan Rakyat." Special issue, Suara Pembaruan Agraria XVI (September-December). http:// kpa.or.id/assets/uploads/files/publikasi/c6235-spa_16_septdes_2015.pdf.
KPA. 2016. Catatan Akhir Tahun 2015: Reforma Agraria dan Penyelesaian Konflik Agraria Disandera Birokrasi, Jakarta: KPA. http://kpa.or.id/publikasi/baca/laporan/31/Catahu_2015:_ Reforma_Agraria_dan_Penyelesaian_Konflik_Agraria_ Disandera_Birokrasi/.

\section{KPA. 2017. Catatan Akhir Tahun 2016: Liberalisasi Agraria} Diperhebat, Reforma Agraria Dibelokkan. Jakarta: KPA. http://kpa. or.id/publikasi/baca/laporan/15/Catahu_2016:__Liberalisasi_ Agraria_Diperhebat__Reforma_Agraria_Dibelokkan/.

KPA. 2018. Catatan Akhir Tahun 2017: Reforma Agraria di Bawah Bayang Investasi, Gaung Besar di Pinggiran Jalan. Jakarta: KPA. http://kpa.or.id/publikasi/baca/laporan/25/Catahu_2017: Reforma_Agraria_di_Bawah_Bayang_Investasi__Gaung_ Besar_di_Pinggiran_Jalan/.

KPA. 2019. Catatan Akhir Tahun 2018: Masa Depan Reforma Agraria Melampaui Tahun Politik، Jakarta: KPA. http://kpa.or.id/ publikasi/baca/laporan/30/Catahu_2018:_Masa_Depan_ Reforma_Agraria_Melampaui_Tahun_Politik/.

\section{KPA. 2020. Catatan Akhir Tahun 2019 Konsorsium Pembaruan} Agraria: Dari Aceh Sampai Papua: Urgensi Penyelesaian Konflik Struktural dan Jalan Pembaruan Agraria ke Depan. Jakarta: KPA. http://kpa.or.id/publikasi/baca/laporan/82/Catahu_2019:_Dari_ Aceh_Sampai_Papua_-_Urgensi_Penyelesaian_Konflik_ Agraria_Struktural_dan_Jalan_Pembaruan_Agraria_ke_ Depan/.

KPA. 2021. Catatan Akhir Tahun 2020 Konsorsium Pembaruan Agraria: Edisi Peluncuran I _ Laporan Konflik Agraria di Masa Pandemi dan Krisis Ekonomi. Jakarta: KPA. http://kpa.orid/ assets/uploads/files/publikasi/4db26-catatan-akhir-tahunkpa_peluncuran-1_laporan-konflik-agraria-2020.pdf.

Kuncoro, A. 2002. "The New Laws of Decentralization and Corruption in Indonesia: Examination of Provincial and District Data." Conference Paper ersa02p053. Louvain-la-Neuve, Belgium: European Regional Science Association. https://ideas.repec. org/p/wiw/wiwrsa/ersa02p053.html.

Kurniawan, N.I. 2014. "An Agrarian Reform Agenda for Jokowi." Inside Indonesia, December 9. https://www.insideindonesia.org/ an-agrarian-reform-agenda-for-jokowi.

Kurniawan, N.I. 2016. "Getting the One Map Policy Right." Indonesia at Melbourne. May 12. https://indonesiaatmelbourne. unimelb.edu.au/getting-one-map-policy-right/.

Li, T.M. 2007. The Will to Improve: Governmentality, Development, and the Practice of Politics. Durham, NC: Duke University Press.

Lucas, $A_{1}$, and C. Warren, eds. 2013. Land for the People: The State and Agrarian Conflict in Indonesia. Athens: Ohio University Press. https://www.jstor.org/stable/j.ctt46n3nz.

MacAndrews, C. 1986. Land Policy in Modern Indonesia: A Study of Land Issues in the New Order Period. Boston: Umi Research.

Matthew, R, 0. Brown, and D. Jensen. 2009. From Conflict to Peacebuilding: The Role of Natural Resources and the Environment. Nairobi: United Nations Environment Programme. https://www.ilisd.org/library/conflict-peacebuilding-role-naturalresources-and-environment. 
Maxton-Lee, B. 2020. Forest Conservation and Sustainability in Indonesia: A Political Economy Study of International Governance Failure. Abingdon, UK: Routledge.

McGregor, K. 2009. "The Indonesian Killings of 1965-1966." Mass Violence \& Resistance, August 4. https://www.sciencespo. $\mathrm{fr} /$ mass-violence-war-massacre-resistance/en/document/ indonesian-killings-1965-1966

Meier, K.J. 1997. "Bureaucracy and Democracy: The Case for More Bureaucracy and Less Democracy." Public Administration Review 57 (3): 193-99. https://doi.org/10.2307/976648.

Michon, G. 2005. Domesticating Forests: How Farmers Manage Forest Resources. Paris: Institut de Recherche pour le Développement, Jakarta: Center for International Forestry Research, and Bogor: ICRAF, https://www.cifor.org/publications/ pdf_files/Books/BMichon0501E1.pdf.

Moeliono, T.P. 2011. "Spatial Management in Indonesia: From Planning to Implementation-Cases from West Java and Bandung. A Socio-Legal Study." PhD diss, Van Vollenhoven Institute, Faculty of Law, Leiden University. http://hdl.handle. net/1887/18242.

Muhajir, M. 2015. "Satu Tahun Perber 4 Menteri Tentang Penyelesaian Penguasaan Tanah di Dalam Kawasan Hutan: Kendala, Capaian dan Arah ke Depan." Policy Brief 2. Jakarta: Epistema Institute. http://www.epistema.or.id/download/Policy_ Brief_Epistema_Institute_vol_2-2015.pdf.

Muhajir, M., M.S.W. Sumardjono, T. Manurung, and J. Ferdinand. 2020. "Harmonisasi Regulasi dan Perbaikan Tata Kelola Sumber Daya Alam di Indonesia." Jurnal Antikorupsi Integritas 5 (2-2): 1-13. https://doi.org/10.32697/integritas.v5i2-2.

Munden Project. 2012. The Financial Risks of Insecure Land Tenure: An Investment View. Washington, DC: Rights and Resources Initiative. https://rightsandresources.org/wp-content/ exported-pdf/rritenureriskreportfinaldec2012.pdf.

Nasution, A. 2016، "Government Decentralization Program in Indonesia." Working Paper 601. Tokyo: Asian Development Bank. https://www.adb.org/publications/government-decentralizationprogram-indonesia.

Naylor, R.L., M.M. Higgins, R.B. Edwards, and W.P. Falcon. 2019. "Decentralization and the Environment: Assessing Smallholder Oil Palm Development in Indonesia." Ambio 48 (10): 1195-1208, https://doi.org/10.1007/s13280-018-1135-7.

Nugraha, I. 2018. "Sektor Agraria dan Tata Ruang Pada Empat Tahun Jokowi, Seperti Apa?" Mongabay, October 31. https://www. mongabay.co.id/2018/10/31/sektor-agraria-dan-tata-ruang-padaempat-tahun-jokowi-seperti-apa/.

Nugraha, I. 2019. "Komnas HAM Minta DPR Tunda Pengesahan RUU Pertanahan." Mongabay, September 9. https://www. mongabay.co.id/2019/09/09/komnas-ham-minta-dpr-tundapengesahan-ruu-pertanahan/.
Nugraha, I., and H.N. Jong. 2019. "Audit BPK Temukan Banyak Perkebunan Sawit Besar Bermasalah." Mongabay, August 27. https://www.mongabay.co.id/2019/08/27/audit-bpk-temukanbanyak-perkebunan-sawit-besar-bermasalah/.

Oxford Business Group. 2015. "Indonesia Introduces One Map Policy as a Solution to Overlapping Land Claims." https:// oxfordbusinessgroup.com/overview/indonesia-introduces-onemap-policy-solution-overlapping-land-claims.

Pattiro (Pusat Telaah dan Informasi Regional). 2019. Akselerasi Perhutanan Sosial dan Rehabilitasi Hutan dan Lahan Dalam Perencanaan Pembangunan Kehutanan: Masukan Untuk Draf RPJMN 2020-2024. Policy Brief. South Jakarta: Pattiro. http:// pattiro.org/en/2019/06/policy-brief-akselerasi-perhutanansosial-rehabilitasi-hutan-lahan-dalam-perencanaanpembangunan-kehutanan/.

Pausacker, H. 2018. "The Soeharto Family: Where Are They Now?" Indonesia at Melbourne, May 23. https://indonesiaatmelbourne. unimelb.edu.au/the-soeharto-family-where-are-they-now/.

Pelzer, K. 1982. "The Indonesian Communist Party and the Agrarian Issue." In Planters against Peasants: The Agrarian Struggle in East Sumatra 1947-1958, 30-46. Leiden, Netherlands: Brill, https://www.jstor.org/stable/10.1163/j.ctt1w8h18s.9.

PRB (Population Reference Bureau). 2001. "Environmental Scarcity and the Outbreak of Conflict." January 1. https://www. prb.org/environmentalscarcityandtheoutbreakofconflict/.

Pyman, M., T. Bock, E. Vidal de la Blache, S. Mustafa, and D. Zaum. 2014. Corruption as a Threat to Stability and Peace. Berlin: Transparency International. https://ti-defence.org/wp-content/ uploads/2016/03/2014-01_CorruptionThreatStabilityPeace.pdf.

Rachman, N.F. 2011. "The Resurgence of Land Reform Policy and Agrarian Movements in Indonesia." PhD diss., University of California, Berkeley. https://digitalassets.lib.berkeley.edu/etd/ ucb/text/Rachman_berkeley_0028E_11750.pdf.

Rachman, N.F. 2012. Land Reform Dari Masa Ke Masa: Perjalanan Panjang Menjajaki Gunung Kebenaran. Yogyakarta, Indonesia: Tanah Air Beta and Konsorsium Pembaruan Agraria.

Raleigh, C., and H. Urdal. 2007. Climate Change, Environmental Degradation and Armed Conflict. In "Climate Change and Conflict," edited by R. Nordås and N.P. Gleditsch, special issue, Political Geography 26 (6): 674-94. https://doi.org/10.1016/j. polge0.2007.06.005

Ray, D., and J. Esteban. 2017. "Conflict and Development." Annual Review of Economics 9 (August): 263-93, https://doi.org/10.1146/ annurev-economics-061109-080205.

Reinjani, D. 2018. "KPA: Belasan Orang Tewas dan Ratusan Orang Dikriminalisasi Akibat Sengketa Lahan." KBR, May 2. https:// $\mathrm{kbr.id} / \mathrm{nasional} / 05-2018 / \mathrm{kpa}$ _belasan_orang_tewas_dan_ ratusan_orang_dikriminalisasi_akibat_sengketa_lahan/95950, html.

Renner, M. 2002. Anatomy of Resource Wars: October 2002. Edited by Thomas Prugh. Washington, DC: Worldwatch Institute. 
Riaño, J., R. Hodess, and A. Evans. 2009. Global Corruption Barometer Report 2009. Berlin: Transparency International. https://images.transparencycdn.org/images/2009_GCB_EN.pdf.

Risalah, D.F. 2020. "KPK: Titik Rawan Korupsi, Tata Ruang Jadi Tata Uang." Republika Online, February 27. https://republika.co.id/ share/q6cpzn430.

Safitri, M.A., N. Ramdhaniaty, Y. Arizona, G.A. Abimanyu, M. Muhajir, and I. Arsyad. 2015. "Legality and Justice in the Establishment of Forest Zones in Indonesia." Policy Paper 4. Jakarta: Epistema Institute.

Sahide, M.A.K., M.R. Fisher, A. Maryudi, A. Dhiaulhaq, C. Wulandari, Y.-S. Kim, and L. Giessen. 2018. "Deadlock Opportunism in Contesting Conservation Areas in Indonesia." Land Use Policy 77 (September): 412-24. https://doi.org/10.1016/j. landusepol.2018.05.020.

Schreiber, L., and J. Schneider. 2017. A Work in Progress: Upgrading Indonesia's National Land Agency, 2004-2014. Princeton, NJ: Innovations for Successful Societies, Princeton University. https://successfulsocieties.princeton.edu/ sites/successfulsocieties/files/LS_Land_Indonesia_ Formatted_12.12.17_1.pdf.

Shenon, P. 1998. "The Suharto Billions-a Special Report: For Asian Nation's First Family, Financial Empire Is in Peril." New York Times, January 16. https://www.nytimes.com/1998/01/16/ business/suharto-billions-special-report-for-asian-nation-s-firstfamily-financial-empire.html.

Siscawati, M. 2017. Laporan Final Pembelajaran Dari Mediasi Konflik Sumber Daya Alam di Indonesia dan Negara Lain. Jakarta: Conflict Resolution Unit, Indonesia Business Council for Sustainable Development, https://www.conflictresolutionunit.id/ wp-content/uploads/2019/03/FA-ID-22112017.pdf.

Sopian, N.L. 2014. "Power Struggle over Land: Decentralization, Land Tenure Security, and the Rule of Law in Indonesia." Equality Development and Globalization Studies (EDGS) Working Paper 19 Evanston, IL: EDGS, Northwestern University. https://www.edgs. northwestern.edu/documents/working-papers/power-struggleover-land.pdf.

Sopian, N.L. 2015. "Informal Dispute Resolution Based on Adat Law: A Case Study of Land Dispute in Flores, East Nusa Tenggara, Indonesia." Indonesia Law Review 5 (2): 106-22. https://doi. org/10.15742/ilrev.v5n2.157.

Srinivas, S., K.C. Bell, B. Collier, J. Wallace, and L. Hidayt. 2014. Towards Indonesian Land Reforms: Challenges and Opportunities: A Review of the Land Sector (Forest and Nonforest) in Indonesia. Washington, DC: World Bank.

Srinivas, S., K.C. Bell, K. Toha, A. Zaenal, and W. Collier. 2015. "A Review of Indonesian Land-Based Sectors with Particular Reference to Land Governance and Political Economy." Presented at the Annual World Bank Conference on Land and Poverty, Washington, DC, March 23-27.

Susan, N. 2015. "Democracy, Land Conflict and Governance in Indonesia: A Case Study of Land Conflict in Lampung Province (2010-2012)." PhD diss., Graduate School of Global Studies, Doshisha University.
Thea, A. 2020. "Capaian Minim, Koalisi Minta Presiden Jokowi Pimpin Reforma Agraria." Hukumonline.com, January 7. https:// www.hukumonline.com/berita/baca/lt5e133904ec096/capaianminim--koalisi-minta-presiden-jokowi-pimpin-reforma-agraria.

Tjondronegoro, S.M.P. 2006. "Land Policies in Indonesia." Working Paper 37435. Washington, DC: World Bank. http://documents. worldbank.org/curated/en/777651468260378738/Land-policiesin-Indonesia.

Transparency International. 2019. Corruption Perceptions Index 2018. Berlin: Transparency International. https://www. transparency.org/files/content/pages/CPI_2018_Executive_ Summary_EN.pdf.

Tresya, D., I. Mayasari, and A.A. Suhendra. 2019. "Penataan Perizinan dalam Gerakan Nasional Penyelamatan Sumber Daya Alam di Indonesia." Integritas: Jurnal Antikorupsi 5 (2-2): 15-31. https://doi.org/10.32697/integritas.v5i2-2.480.

UN DESA (United Nations Department of Economic and Social Affairs). 2005. Unlocking the Human Potential for Public Sector Performance: World Public Sector Report 2005. New York: United Nations.

\section{UN DESA. 2016. World Economic and Social Survey} 2014/2015: Learning from National Policies Supporting MDG Implementation. New York: UN DESA. https://www.un.org/ development/desa/dpad/wp-content/uploads/sites/45/ publication/2015wess_es_en.pdf.

UN Framework Team (United Nations Interagency Framework Team for Preventive Action). 2012. Toolkit and Guidance for Preventing and Managing Land and Natural Resources Conflict: Extractive Industries and Conflict. New York: United Nations Development Programme. https://www.un.org/en/land-naturalresources-conflict/pdfs/GN_ExeS_Extractive\%20Industries\%20 and\%20Conflict.pdf.

VOA (Voice of America). 2018. "Indonesia Reforms Seek to Solve Decades of Land Conflict." December 11. https://www.voanews. com/east-asia-pacific/indonesia-reforms-seek-solve-decadesland-conflict.

World Bank. 2014. "World Bank and Environment in Indonesia." August 1. https://www.worldbank.org/en/country/indonesia/ brief/world-bank-and-environment-in-indonesia.

World Bank. 2018a. "Nearly 4.3 Million to Benefit from Indonesia's Sustainable Land Management." July 20. https://www.worldbank. org/en/news/press-release/2018/07/20/indonesia-sustainableland-management.

World Bank. 2018b. Project Appraisal Document on a Proposed Loan in the Amount of US\$200 Million to the Republic of Indonesia for a Program to Accelerate Agrarian Reform (One Map Project). Report PAD2748. Washington, DC: World Bank. http:// documents.worldbank.org/curated/en/393931532143851037/pdf/ Indonesia-One-Map-PAD-06262018.pdf.

Wrangham, R. 2002. "Changing Policy Discourses and Traditional Communities, 1960-1999." In Which Way Forward? People, Forests, and Policymaking, edited by C.J. Pierce Colfer and I.A.P. Resosudarmo. Washington, DC: Resources for the Future. 
Wulan, Y.C., Y. Yasmi, C. Purba, and E. Wollenberg. 2004. Analisa Konflik Sektor Kehutanan di Indonesia 1997-2003. Bogor: Center for International Forestry Research. https://doi.org/10.17528/ cifor/001614.

Yuliawati. 2017. "Industri Kelapa Sawit Khawatir Dampak Dibukanya Data HGU untuk Publik." Katadata.co.id, June 29. https://katadata.co.id/berita/2017/06/29/industri-kelapa-sawitkhawatir-dampak-dibukanya-data-hgu-untuk-publik.

Zakaria, R.Y., R. Pradiptyo, P. Iswari, and P.S. Wibisana. 2019. The Cost of Land and Natural Resources Conflict: A Community Perspective, translated by L.A. Fisher. Jakarta: Conflict Resolution Unit, Indonesia Business Council for Sustainable Development. https://www.conflictresolutionunit.id/wp-content/ uploads/2019/03/Summary-Biaya-Konflik-20180428.pdf.

Zuhra, W.U.N. 2017. "Target Kedaulatan Pangan Jokowi yang Gagal Dicapai." Tirto.id, July 12. https://tirto.id/target-kedaulatanpangan-jokowi-yang-gagal-dicapai-csuG. 


\section{ABOUT WRI}

World Resources Institute is a global research organization that turns big ideas into action at the nexus of environment, economic opportunity, and human well-being.

\section{Our Challenge}

Natural resources are at the foundation of economic opportunity and human well-being. But today, we are depleting Earth's resources at rates that are not sustainable, endangering economies and people's lives. People depend on clean water, fertile land, healthy forests, and a stable climate. Livable cities and clean energy are essential for a sustainable planet. We must address these urgent, global challenges this decade.

\section{Our Vision}

We envision an equitable and prosperous planet driven by the wise management of natural resources. We aspire to create a world where the actions of government, business, and communities combine to eliminate poverty and sustain the natural environment for all people.

\section{Our Approach}

COUNT IT

We start with data. We conduct independent research and draw on the latest technology to develop new insights and recommendations. Our rigorous analysis identifies risks, unveils opportunities, and informs smart strategies. We focus our e orts on influential and emerging economies where the future of sustainability will be determined.

\section{CHANGE IT}

We use our research to influence government policies, business strategies, and civil society action. We test projects with communities, companies, and government agencies to build a strong evidence base. Then, we work with partners to deliver change on the ground that alleviates poverty and strengthens society. We hold ourselves accountable to ensure our outcomes will be bold and enduring.

\section{SCALE IT}

We don't think small. Once tested, we work with partners to adopt and expand our e orts regionally and globally. We engage with decision-makers to carry out our ideas and elevate our impact. We measure success through government and business actions that improve people's lives and sustain a healthy environment.

\section{PHOTO CREDITS}

Cover photo, pg. 27, 41 Ahmad; pg. iv, 36 Munthe; pg. vi Safwan; pg. 8-9, 14, 15, 18, 19, 32-33 Anderson; pg. 10 Global Forest Watch Fires; pg. 13 Purwanti; pg. 16 Fazli; pg. 23, 31 Minnick; pg. 24-25 Purnama; pg. 28 Hendrawan; pg. 42 Sitompul. 



\title{
WRI INDONESIA
}

\author{
WISMA PMI, $3^{\text {rd }}$ FLOOR \\ JALAN WIJAYA I N0.63 \\ SOUTH JAKARTA 12170 \\ +62 2122775816 \\ WRI-INDONESIA.ORG
}

